\title{
Sub-surface stratigraphy and petrophysical analysis of the Middle Devonian interval of the central Appalachian basin; West Virginia and southwest Pennsylvania
}

\author{
Matthew Louis Boyce \\ West Virginia University
}

Follow this and additional works at: https://researchrepository.wvu.edu/etd

\section{Recommended Citation}

Boyce, Matthew Louis, "Sub-surface stratigraphy and petrophysical analysis of the Middle Devonian interval of the central Appalachian basin; West Virginia and southwest Pennsylvania" (2010). Graduate Theses, Dissertations, and Problem Reports. 3195.

https://researchrepository.wvu.edu/etd/3195

This Dissertation is protected by copyright and/or related rights. It has been brought to you by the The Research Repository @ WVU with permission from the rights-holder(s). You are free to use this Dissertation in any way that is permitted by the copyright and related rights legislation that applies to your use. For other uses you must obtain permission from the rights-holder(s) directly, unless additional rights are indicated by a Creative Commons license in the record and/ or on the work itself. This Dissertation has been accepted for inclusion in WVU Graduate Theses, Dissertations, and Problem Reports collection by an authorized administrator of The Research Repository @ WVU.

For more information, please contact researchrepository@mail.wvu.edu. 


\title{
SUB-SURFACE STRATIGRAPHY AND PETROPHYSICAL ANALYSIS OF THE MIDDLE DEVONIAN INTERVAL OF THE CENTRAL APPALACHIAN BASIN; WEST VIRGINIA AND SOUTHWEST PENNSYLVANIA
}

\author{
Matthew Louis Boyce
}

Dissertation submitted to the Eberly College of Arts and Sciences of West Virginia University in partial fulfillment of the requirements for the degree of

Doctor of Philosophy

in Geology

Dr. Timothy R. Carr, Ph.D., Chair

Dr. Richard Smosna, Ph.D.

Dr. Jack Renton, Ph.D.

Dr. Jaime Toro, Ph.D.

Dr. Mohindar Seehra, Ph.D.

Department of Geology and Geography

Morgantown, West Virginia 2010

Keywords: Middle Devonian Stratigraphy; Middle Devonian Shale Petrophysics; Marcellus Depositional Model; Marcellus Shale Analysis

Copyright 2010 Matt Boyce 


\begin{abstract}
Sub-Surface Stratigraphy and Petrophysical Analysis of the Middle Devonian Interval of the Central Appalachian Basin; West Virginia and Southwest Pennsylvania
\end{abstract}

\title{
Matthew Louis Boyce
}

In the central Appalachian basin, the Middle Devonian organic-rich shale interval, including the Marcellus Shale, is an important target for natural gas exploration. It has emerged as a giant unconventional resource play due to aerial extent and potential for individual wells to produce large volumes of gas. The Marcellus Shale is well studied on the surface without the incorporation of the subsurface stratigraphy. However, to fully understand the Marcellus economic potential it is important to investigate and map the related Middle Devonian sub-surface stratigraphic units. The interval studied includes the Onondaga Limestone (Eifelian), Marcellus Shale (Eifelian), Purcell Limestone (Eifelian), Mahantango Shale (Givetian), Tully Limestone (Givetian), and Harrell Shale (FransnianGivetian). The first goal of this study is to establish a sub-surface lithostratigraphic framework for the Middle Devonian interval using rigorously defined well log criteria integrated with X-ray diffraction, TOC, and petrophysical data. Secondly, this study advances the understanding of well log response in organic-rich shale units to derive important reservoir properties (e.g., organic-richness, gas content and lithology) using a combination of readily available well logs (gamma ray, neutron porosity, bulk density, photo electric, and resistivity curves) and the more modern spectral gamma ray logs. Using log data, a relationship was recognized between the uranium concentration, and increased gas content and organic richness. The incorporation of the spectral gamma ray logs and the traditional well logs available in the basin allowed for new methods of gas identification as well as the re-defining of water saturation calculations for the Middle Devonian interval that can be used to locally evaluate economic potential. Finally this study used the litho-stratigraphic framework and defined well log relationships to create a regional picture of the depositional dynamics for the Middle Devonian interval. Local depositional trends were observed in which deeper structures affected the local topography and created conditions that were more favorable for organic matter accumulation and preservation. Regionally, a trend striking north-west to south-east marked an area of increased organic preservation as well as distinct changes in unit thicknesses. This trend persists and affects depositional patterns for the entire interval, creating a shelf-break environment that was topographically higher to the east and north. The local and regional trends and their affect on the deposition of all of the stratigraphic units, allows for improved recognition of areas for economic gas production in the Middle Devonian of the central Appalachian basin. 


\section{PREFACE- A note on organization}

The research for this study was completed and then presented and written as three papers in relation to the dissertation topic. The paper in this study titled, Lithostratigraphy and Petrophysics of the Devonian Marcellus Interval in West Virginia and Southwestern Pennsylvania, was submitted and published at the $29^{\text {th }}$ Annual GCSEPM Foundation Bob F. Perkins Research Conference in December, 2009. While this paper was chronologically published first, it is the second chapter in the study in order to illustrate a progression of thought in the dissertation. The third chapter and last paper in this study has been submitted to the AAPG Bulletin and is under review. The first chapter and first paper will be submitted to another peer reviewed journal. The above mentioned journals differed in submission standards from the requirements of the university and therefore, some figures have been altered in-order to fulfill these requirements. Also, two crosssections have been included in the Appendix of this study to illustrate some of the correlations made in this study. DD 


\section{ACKNOWLEDGEMENTS}

This study was made possible by the donation and support of many organizations. The organizations that contributed a vast amount of data and funding include Consol Energy (formerly Dominion Exploration), EQT Corporation, and NETL labs. I sincerely appreciate the help and feed back during my time here. Also, I was fortunate enough while in West Virginia to have met many other geoscientists in industry who always provided valuable information on my work.

I would like to thank my advisor and mentor, Dr. Tim Carr. Thank you for taking a chance on me and allowing me to work with you on my PhD. It has been an incredible experience to work under your guidance and mentorship. I truly cannot describe or convey the lessons that I learned professionally as well as in life. So once again thank you for everything guy.

I would also like to send a sincere thank you to the rest of the faculty for my continued education in the geosciences. The experiences and lessons I was taught have influenced my life and is another reason for which I graduated in a respectable time period with a job in waiting. While I was at West Virginia University I had the privilege to be part of student organizations in the department that were supported by the faculty. These organizations were great, but I really wanted to send a thank you to Dr. Trevor Harris. These organizations really help us students interact with students and faculty, as well as enhance our professional development while in school. Dr. Harris has been a great supporter of the student organization and I really just wanted to take this opportunity to acknowledge the support he gave me and other students while I was here.

In addition to the faculty, I would like to thank the other students in the geology as well as in Morgantown. Over the years here I have made invaluable friends and will always 
remember and value all of the experiences. I really wanted to extend a special thanks to Anne Yanni. Thank you for putting up with me and my requests for editing. I promise I will not forget how to use a semi-colon.

Lastly and most importantly I wanted to thank my parents and family. You have always been there to support me and have continued that un-wavering support, even when it required me to be in school for such a long time. Without your encouragement and love I would have never been able to accomplish this and sincerely thank you for everything. 


\section{TABLE OF CONTENTS}

SUB-SURFACE STRATIGRAPHY AND PETROPHYSICAL ANALYSIS OF THE MIDDLE DEVONIAN INTERVAL OF THE CENTRAL APPALACHIAN BASIN; WEST VIRGINIA AND SOUTHWEST PENNSYLVANIA..............

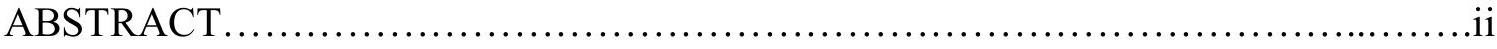

PREFACE- A note on organization.....................................................

ACKNOWLEDGEMENTS ........................................................

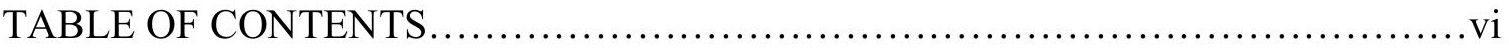

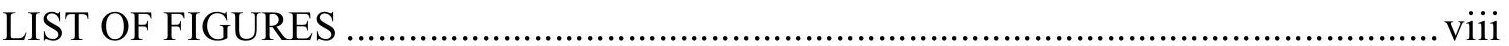

1.0 Core and Petrophysical Analysis of the Middle Devonian Shale Interval in Southwest Pennsylvania and West Virginia............................................................................. 1

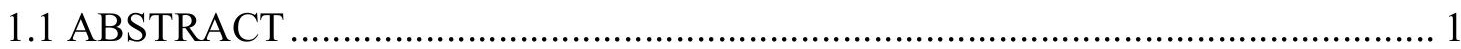

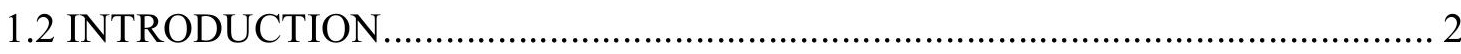

1.3 DATA AND SUB-SURFACE CORRELATIONS .................................................. 8

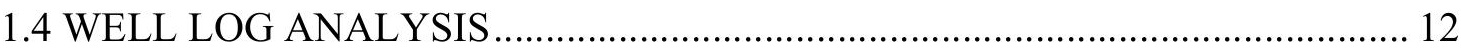

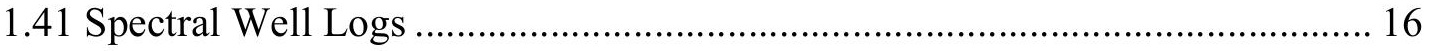

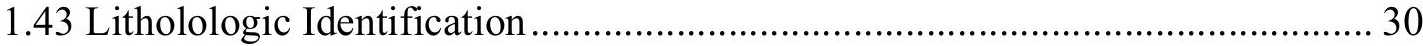

1.44 Spectral-Bulk Density Cross-Plot..................................................................... 33

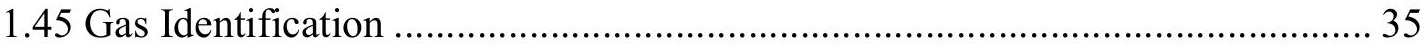

1.45 Modified Water Saturation Calculations …………………………………....... 40

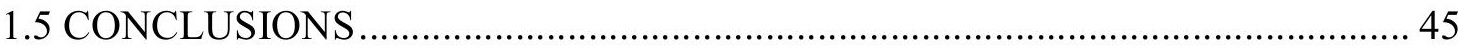

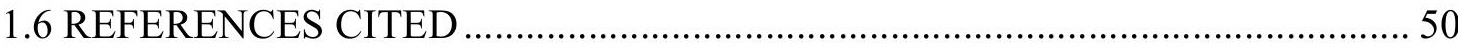

2.0 Lithostratigraphy and Petrophysics of the Devonian Marcellus Interval in West Virginia and Southwestern Pennsylvania ……………………................................... 53

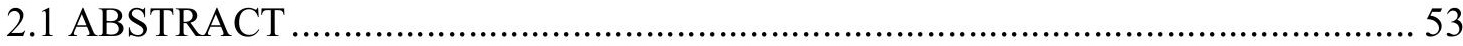

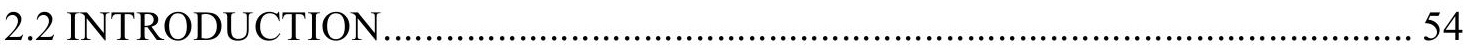

2.2 MIDDLE DEVONIAN LITHOSTRATIGRAPHIC UNITS .................................. 60

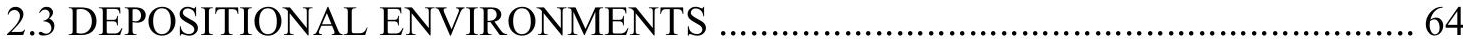

1.4 LITHOLOGIC ANALYSIS AND RECOGNITION OF GAS-RICH INTERVALS

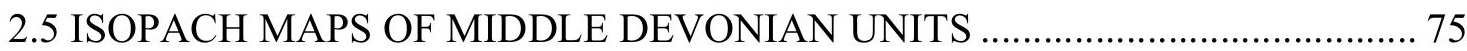

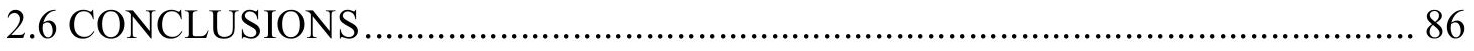


2.7 REFERENCES CITED. 88

3.0 The Depositional Dynamics of the Middle Devonian Marcellus Interval Using a Petrophysical and Stratigraphic Analysis of the Sub-surface in West Virginia and Southwestern Pennsylvania ................................................................................... 90

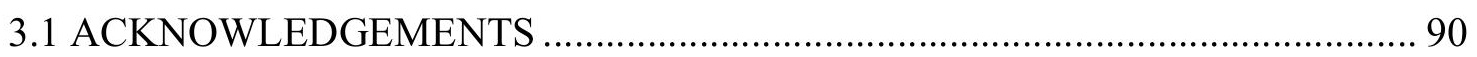

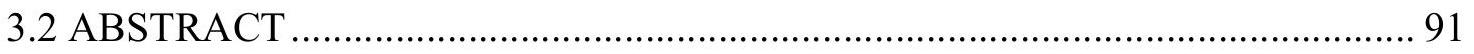

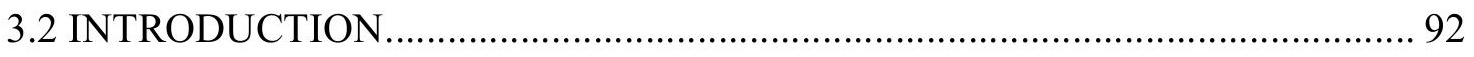

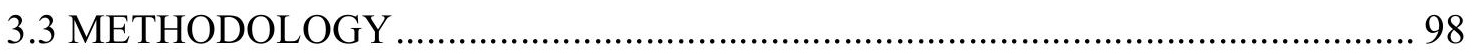

3.31 Definition of Subsurface Stratigraphic Units ................................................. 99

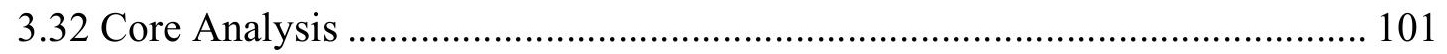

3.33 Spectral Gamma Ray Log Analysis............................................................ 103

3.4 MIDDLE DEVONIAN DEPOSITIONAL PATTERNS .................................. 115

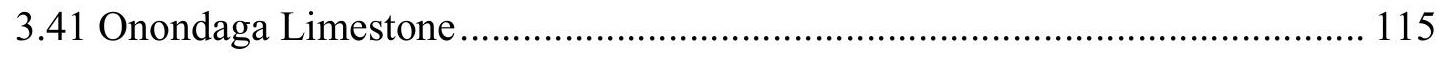

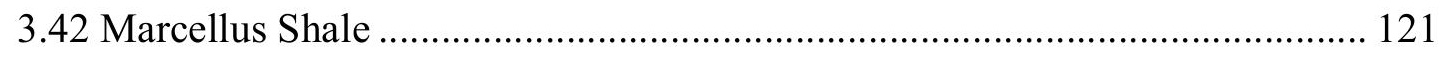

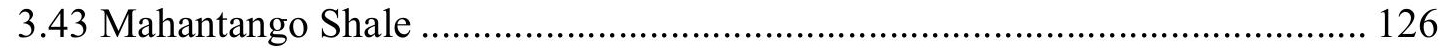

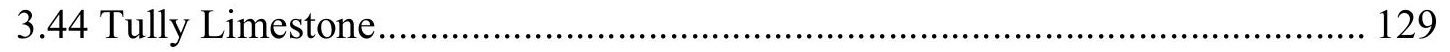

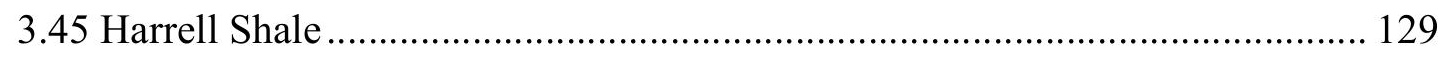

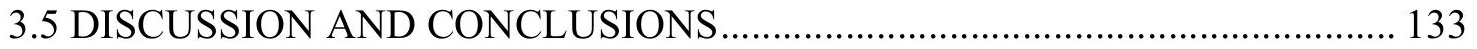

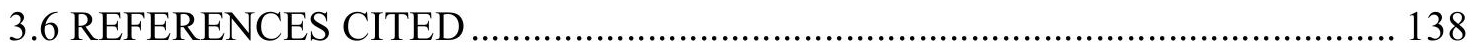

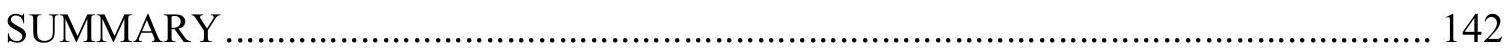

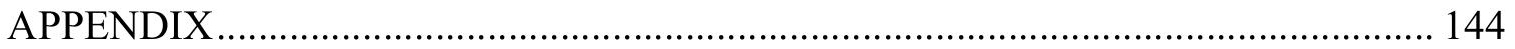




\section{LIST OF FIGURES}

Figure 1-1. The study area encompasses the state of West Virginia (WV) and southwest Pennsylvania (PA)..

Figure 1-2. Stratigraphic column for the study area compared to the time equivalent units

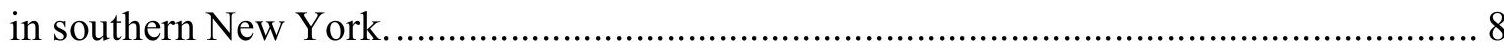

Figure 1-3. Type log for the Marcellus, Purcell, Onondaga, and Needmore units in southwest Pennsylvania and West Virginia............................................................ 10

Figure 1-4. Type log for the entire Middle Devonian interval for the study area in southwest Pennsylvania and West Virginia

Figure 1-5. Plot illustrating the positive relationship between total organic carbon (TOC) and pyrite.

Figure 1-6. Plot illustrating the negative relationship between total organic carbon (TOC) and bulk density (RHOB)

Figure 1-7. Plot illustrating the absence of a relationship between pyrite and bulk density (RHOB).

Figure 1-8. Plot illustrating the relationship between illite percentages obtained from core data and the thorium (Th) content ( $\mathrm{ppm}$ ) obtained from the spectral log.

Figure 1-9. Plot illustrating the negative relationship between quartz percentages obtained from core data and the thorium (Th) content (ppm) obtained from the spectral log....... 21

Figure 1-10. Plot illustrating the relationship between the resistivity curve and the thorium (Th) concentration (ppm) as measured by the spectral gamma ray log....

Figure 1-11. Plot of the uranium (U) concentration (ppm) derived from the spectral gamma ray log against the standard gamma ray (SGR in API units). 23 
Figure 1-12. Well log illustrating two generated curves from the spectral gamma ray log to predict redox conditions and clay type.

Figure 1-13. Illustration of two wells with core data used to calibrate the predicted total organic carbon (TOC) content from the bulk density (RHOB) and uranium (U) content (ppm) from the spectral log.

Figure 1-14. Plot of the measured total organic carbon (TOC) content (percent) measured from core data versus the uranium content (ppm) from the spectral log.... 28

Figure 1-15. Interpreted organic richness of the Marcellus Shale illustrated by a map of net thickness of total organic carbon (TOC) content greater than or equal to $7 \%$.

Figure 1-16. RHOmaa-Umaa plot is compared with X-ray diffraction (XRD) results for core sample of the Marcellus Shale. 31

Figure 1-17. Plot illustrating the relationship between the percentage of pyrite and the movement to the right on the Umaa axis 33

Figure 1-18. Cross-plot of uranium (U) in ppm versus density porosity.

Figure 1-19. Log illustrating two methods of gas identification in the Middle Devonian of the Appalachian basin.... 38

Figure 1-20. Plot of the distance away from the line on the density porosity-uranium cross-plot (Figure 18, 19) compared with the vertical difference between the calculated RHOmaa value from the log data and the plotted core data in the RHOmaa-Umaa cross plot (Figure 16).

Figure 1-21. Log illustrating multiple approaches to calculating water and gas saturations in the Marcellus Shale.

Figure 2-1. The study area encompasses of the state of West Virginia and southwest Pennsylvania. 
Figure 2-2.-The study area is outlined in red on the paleogeographic interpretation of the Middle Devonian (385 Ma).

Figure 2-3. Stratigraphic column for the study area.. 59

Figure 2-4. Type log for the interval in the study area of West Virginia and southwest Pennsylvania.

Figure 2-5.- Example of X-Ray Diffraction (XRD) results for a single core sample from the Marcellus in the study area (Figure 1-1).

Figure 2-6. Example of a Rhomaa Umaa plot compared with XRD results from a single core sample of the Marcellus Shale.

Figure 2-7. Crossplot of Uranium in ppm versus density porosity

Figure 2-8. Uranium content and density porosity can be plotted together (Track 2) to highlight potential gas-rich intervals. 71

Figure 2-9. Log illustrating multiple approaches to calculating water and gas saturation in the Marcellus Shale. 74

Figure 2-10. Isopach of the Marcellus Shale across the study area showing a decrease in thickness from over 180 feet $(54.9 \mathrm{~m})$ in the northeast to less than 10 feet $(3 \mathrm{~m})$ in southwest West Virginia.

Figure 2-11. Isopach map of intervals of the Marcellus Shale with gamma-ray values greater than 230 API.

Figure 2-12. Isopach of the Purcell Limestone Member. 81

Figure 2-13. Isopach of the Mahantango Shale. 82 
Figure 2-14. Isopach of the Tully Limestone. 83

Figure 2-15. Isopach of the Harrell Shale.

Figure 3-1. The study area encompasses the state of West Virginia (WV) and southwest Pennsylvania (PA).. 95

Figure 3-2. The study area is outlined in red on the paleogeographic interpretation of the Middle Devonian (385 Ma). 96

Figure 3-3. Stratigraphic column for the study area compared to the time equivalent units in southern New York. 97

Figure 3-4. Type log for the Marcellus, Purcell, Onondaga, and Needmore units in southwest Pennsylvania and West Virginia.

Figure 3-5. Type log for the entire interval for the study area in southwest Pennsylvania and West Virginia.. 108

Figure 3-6. Example of typical X-ray diffraction (XRD) results for a single core sample of the Marcellus Shale in the study area.. 109

Figure 3-7. Example of a RHOmaa-Umaa plot compared with X-ray diffraction (XRD) results for a single core sample of the Marcellus Shale... 110

Figure 3-8. Uranium (U) concentration (ppm) from the spectral gamma ray log and density porosity is plotted on a consistent scale (Track 2) to highlight (cross-over) potential gas rich intervals.

Figure 3-9. Plot of the uranium $(\mathrm{U})$ concentration $(\mathrm{ppm})$ derived from the spectral gamma ray log against the standard gamma ray (SGR in API units). 113 
Figure 3-10. Log plot of thorium-uranium ratio illustrating interpreted changes in oxidizing and reducing conditions during the time of deposition.

Figure 3-11. Isopach of the Onondaga Limestone

Figure 3-12. Isopach map of the black shale observed at the base of the Onondaga Limestone and is interpreted as part of the Needmore Shale that outcrops in western Maryland.

Figure 3-13. Conceptual cross-sectional depositional model for the lower four Middle Devonian units in the central Appalachian basin. 120

Figure 3-14. Net shale isopach of the Marcellus Shale s 123

Figure 3-15. Interpreted organic richness illustrated by a net uranium map of the Marcellus at $15 \mathrm{ppm}$

Figure 3-16. Isopach of the Purcell Limestone Member of the Marcellus Shale. 125

Figure 3-17. Isopach of the Mahantango Shale 128

Figure 3-18. Isopach of the Tully Limestone. 130

Figure 3-19. Conceptual cross-sectional depositional model for the upper two Middle Devonian units in the central Appalachian basin 131

Figure 3-20. Isopach of the Harrell Shale. 132 
1.0 Core and Petrophysical Analysis of the Middle Devonian Shale Interval in Southwest Pennsylvania and West Virginia.

\author{
Boyce, Matthew L \\ Department of Geology and Geography \\ West Virginia University \\ 98 Beechurst Avenue, 330 Brooks Hall \\ Morgantown, WV 26505 \\ E-mail: mboyce5@mix.wvu.edu \\ Carr, Timothy $\mathbf{R}$ \\ Marshall Miller Professor of Geology \\ West Virginia University \\ 98 Beechurst Avenue, 330 Brooks \\ Morgantown, WV 26505 \\ E-mail: tim.carr@mail.wvu.edu
}

\begin{abstract}
1.1 ABSTRACT
The Middle Devonian shale interval in the central Appalachian basin is a developing unconventional resource play that has great potential to produce large volumes of natural gas. In order to properly evaluate the economic potential of the organic-rich shale units including the Marcellus Shale, a large number of available traditional well log types as well as the spectral gamma logs, were calibrated to available core data and used in a number of cross-plots. The presence of pyrite and gas in the Marcellus is readily visible on RHOmaa-Umaa cross-plots. Clay-typing and fluctuations in redox conditions through the Middle Devonian were evaluated using ratios of potassium, thorium and uranium concentrations derived from spectral gamma-ray logs. New and modified methods to identify gas-rich intervals were developed and demonstrated in the form of a density porosity-uranium concentration cross plots. An observed relationship between total organic carbon (TOC) content and the uranium concentration derived from the spectral and calibrated standard gamma ray logs was extrapolated across the basin using a logarithmic relationship to identify gas-rich zones and regions. The classic Archie equation and standard shale corrections were re-evaluated and modified using uranium and thorium concentrations derived from the spectral gamma ray log to include the effects of organic material and bound water, improve estimates of water and gas saturations. The spectral gamma ray log is a relatively low-cost and valuable well log for evaluation of organic-rich gas-shale units such as the Marcellus. Incorporation of the spectral log into newly drilled wells can provide valuable calibration of more common well logs, assist in identification of gas-rich zones and provide improved insight into accumulation and preservation of organic matter and facilitate regional prospecting for gas-shale. With sufficient calibration to core data and newer logs such as spectral gamma ray the Marcellus and related Middle Devonian organic-rich shale units in the Appalachian basin can be effectively evaluated regionally and locally using common well logs.
\end{abstract}




\subsection{INTRODUCTION}

In the eastern United States, the Middle Devonian of the central Appalachian basin has developed into an important natural gas reservoir. In this interval, the Marcellus Shale was long considered to be a primary source rock for the basin, however, the application of fracture stimulation and horizontal wellbores have stimulated exploration and production. The Marcellus may contain approximately 1,300 trillion cubic feet of recoverable gas in the basin (Gold, 2008). The initial estimates and production of gas as well as the large aerial extent of the unit, indicate that the Marcellus is an emerging giant resource play.

Key parameters for determining the potential of gas-shale deposits include: reservoir areal extent and thickness, thermal maturity, total organic carbon (TOC) content, gas content both adsorbed and free gas, rock properties, and permeability (Jenkins and Boyer, 2008). Typically, many of these parameters, such as thermal maturity, rock properties, gas content and TOC for the Marcellus and other gas-shale units, have been measured by core samples (e.g., Repetski and others, 2008).

However, a variety of log analysis methods can also be applied to evaluate shalegas units such as the Marcellus interval. With the recent focus on exploration for gas-rich shale units in the United States (e.g. Barnett, Marcellus, Fayetteville, Haynesville, etc), it has been recognized that the amount of productive gas in unconventional shale plays is tied to key reservoir parameters such as the TOC content, lithology conducive to fracture stimulation and gas content in the reservoir unit. In the last decade, the renaissance in 
shale-gas production has required refinement of existing methodologies and development of new techniques to predict TOC and other physical properties to evaluate the reservoir potential of gas-shale units such as the Marcellus Shale. The application of new specialized logs and methods (e.g. geochemical logs, isotherms) used to identify organicrich and producible gas-shale intervals is useful, but has not been integrated with the extremely large databases of existing wellbores with traditional logging suites typical of onshore mature basins such as the Appalachian basin. It is therefore important to reexamine and re-evaluate shale-gas units using standard well logs that can be extrapolated regionally to evaluate key parameters for determining the potential of gas-shale deposits.

Historically, a well defined relationship has been established between increased gamma ray response and an increase in TOC (Beers, 1945; Swanson, 1960; Schmoker, 1981). Schmoker (1981) specifically identified that in the Devonian Appalachian shale units, the gamma ray values increased as TOC increased. This relationship was largely tied to the abnormally high values of uranium (U) in the standard gamma ray log (Swanson, 1960). However, Schmoker (1981) noted that even though the gamma ray log indicated organic richness, it did not have the required quantitative precision to regionally evaluate organic richness across the basin. Other standard logs have been used to identify TOC rich areas in source rocks, such as the bulk density log. The density log is commonly used to predict organic rich intervals due to its sensitivity to rock properties and the low density of kerogen. However the sensitivity provided by the density tool can hinder the ability to predict organic richness due to the common presence of pyrite in organic rich rocks (Schmoker and Hester, 1983). Also, another potential problem with the pad-based density tool in organic matter prediction is the common presence of wash-out 
in the bore hole for shale units. A rugose borehole can severely alter the density readings and cause inaccurate predictions. Another method that has been widely used to predict organic richness in units such as the Marcellus is thellogR method (Passey and others, 1990; Creaney and Passey 1993). In this method, organic richness can be predicted by overlaying a correctly scaled porosity log (most commonly sonic porosity) against the resistivity curve. While the sonic porosity tool was most commonly used for this method, the density porosity and neutron porosity tool could be used in the Appalachian basin where sonic porosity logs are not widely available. The $\Delta \log R$ method of prediction while accurate is problematic when applied to the Marcellus because of the regional variations in maturity of the Middle Devonian interval. A relationship between the gamma ray and density porosity has been proposed to identify gas-rich zones associated with increased areas of organic matter (Ward, 2008). In this paper we evaluate this relationship between gamma ray and density porosity for identifying gas-rich zones is evaluated for the Marcellus interval and expand it to not only identify zones, but potentially which zones contain more volume of producible gas.

Petrophysical techniques that are typically applied to gas shale units, including the Middle Devonian interval in the study area, were originally derived for shale-rich sandstone units, alternating shale and sandstone units, or siltstone units. While some of these techniques have application for the shale intervals (i.e. RHOmaa-Umaa plot) (Doveton, 1994), new techniques are required to account for the variability between petrophysical properties of sand and shale. The calculation of water saturation, and by subtraction hydrocarbon saturation, in a reservoir interval is a standard approach to the economic evaluation. In shale-gas units, such as the Middle Devonian Marcellus 
interval, the standard methods developed for sandstone and limestone reservoir intervals (i.e. Archie and Simandoux equations) require modification to improve prediction of saturation levels. These classic equations are modified to recognize reservoir properties associated with organic-rich shale units to improve the prediction of gas and water saturations of the Middle Devonian gas-shale intervals.

Numerous studies have focused on the stratigraphy and depositional dynamics of the Middle Devonian in the study area (Ettensohn, 1998, Hasson and Dennison, 1988). Recent work has focused attention to the relation of the petrophysics to the stratigraphic succession to defined subsurface well log boundary criteria for the interval in order to improve subsurface correlation of stratigraphic units (Boyce \& Carr, 2009). In this paper covering the central Appalachian basin, we use sub-surface definitions that have been tied to core analysis to examine the petrophysical properties of individual Middle Devonian units and their relation to the economic potential within a digital data-set of over 1,607 wells distributed across approximately 23,500 $\mathrm{mi}^{2}\left(60,839 \mathrm{~km}^{2}\right)$ basin (Figure $1-1)$.

The Middle Devonian stratigraphic succession in the study area is in ascending order: Onondaga Limestone (Eifelian), Marcellus Shale (Eifelian), Purcell Limestone (Eifelian), Mahantango Shale (Givetian), Tully Limestone (Givetian), and Harrell Shale (Frasnian-Givetian) (Anderson et. al., 1984, Hasson and Dennison, 1988) (Figure 1-2). In the central Appalachian basin, the generation and preservation of organic material during the periods of organic-rich shale accumulation is not tied directly to the gross thickness of the shale, but the relation to the underlying paleotopography at the time of deposition (Boyce \& Carr, submitted). Considering the relationship between lithology, increased 
total organic carbon and gas content, the petrophysical responses are important to an improved technical understanding of shale-gas units such as the Marcellus and related Middle Devonian shale units of the central Appalachian basin. 


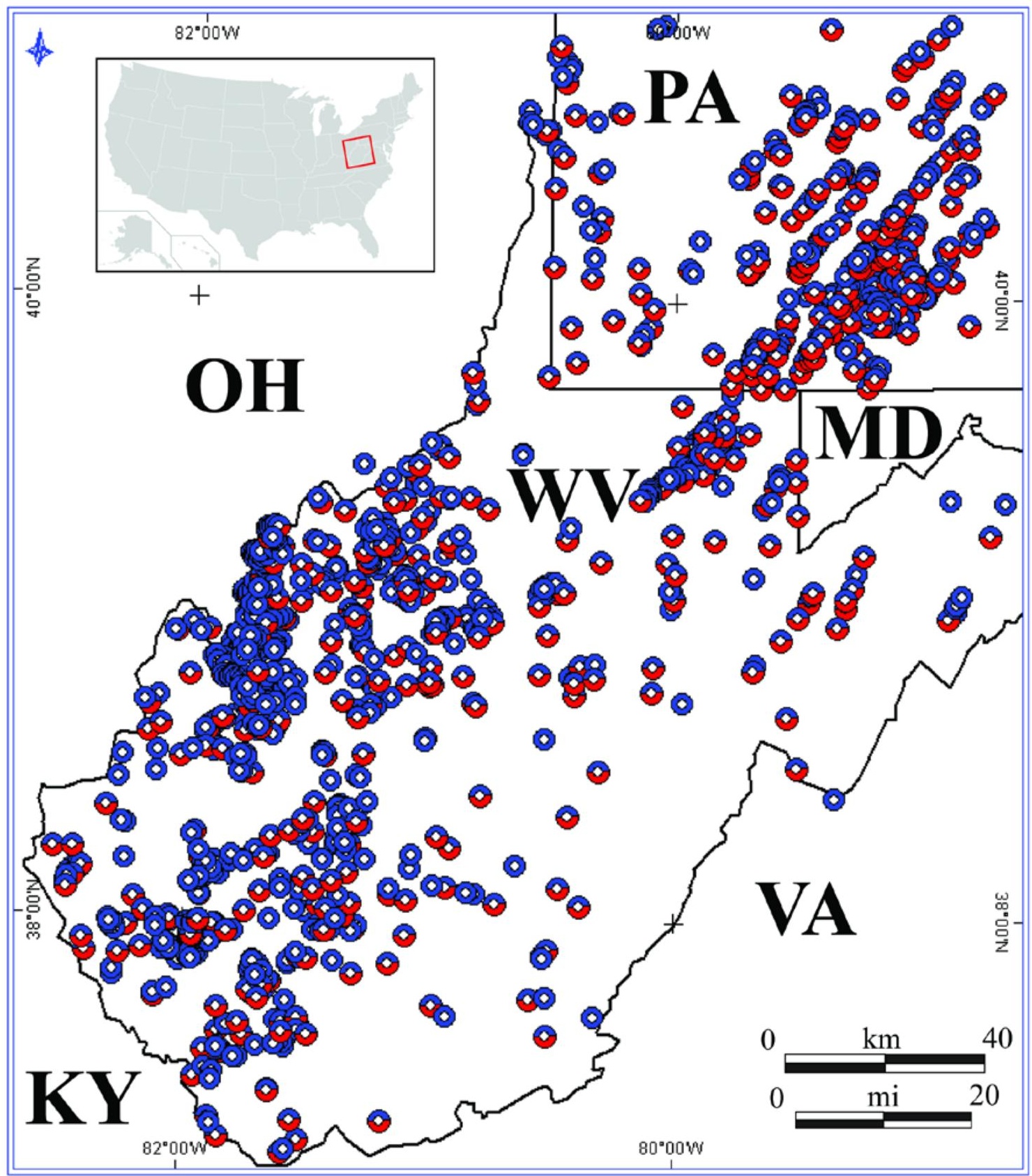

Figure 1-1. The study area encompasses the state of West Virginia (WV) and southwest Pennsylvania (PA). It is located in the geological province of the central Appalachian basin and covers an area of approximately 23,500 $\mathrm{mi}^{2}\left(60,839 \mathrm{~km}^{2}\right)$. A total of 1,607 wells were correlated and are illustrated on the map (blue circles). Of the 1,607 wells correlated 458 wells had digital logs that were used in this study. Selected wells in Ohio $(\mathrm{OH})$ were examined to verify specific depositional trends. 


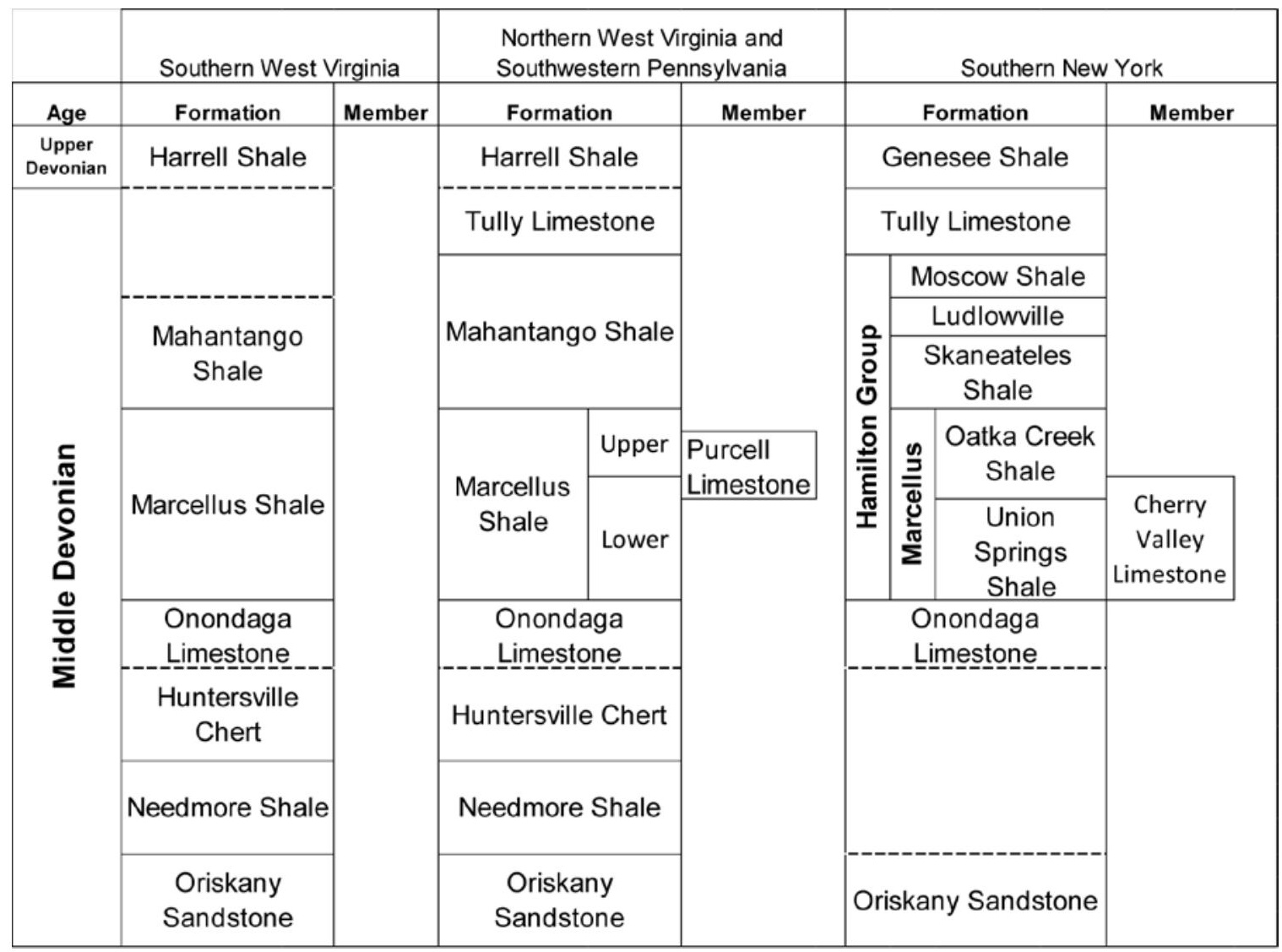

Figure 1-2. Stratigraphic column for the study area compared to the time equivalent units in southern New York. While many of the units in the study area have the same nomenclature as the strata in New York, it is important to recognize there are different formations and stratigraphic relationships in relation to the geography. The units that are the subject of this study are in the two columns labeled southern West Virginia, and northern West Virginia and southwestern Pennsylvania. Dashed lines represent unconformable or erosional surfaces. Compiled from Anderson et. al. (1984), Hasson and Dennison (1988), and Swezey (2002).

\subsection{DATA AND SUB-SURFACE CORRELATIONS}

As part of this study, data were assembled from a variety of sources and consist of core samples, well logs, and core analyses. A total of 35 core samples for the Marcellus Shale and related Middle Devonian units were acquired and analyzed for mineralogy (Xray diffraction), and total organic carbon (pyrolysis). Out of the 1,607 wells with log data, a total of 458 digital well logs were analyzed. The lithostratigraphic boundaries were 
defined using multiple geophysical logs tied to core in order to define petrophysical criteria for each stratigraphic interval (Boyce and Carr, 2009; Boyce and others, submitted). A summary of the criteria used to define stratigraphic units and to generate type logs are shown (Table 1-1, Figures 1-3, 1-4).

\begin{tabular}{|c|c|c|c|}
\hline \multicolumn{4}{|c|}{ Defining Characteristics } \\
\hline Stratigraphic Unit & Gamma Ray & PE Value & Bulk Density \\
\hline Needmore Shale & Aprox. > 150 API & N/A & Aprox. 2.71 \\
\hline Onondaga Limestone & Clean (30 - 110 API) & Aprox. 5 & 2.71 \\
\hline Marcellus Shale & $>200$ API & N/A & $<2.55$ \\
\hline Purcell Limestone & $<200$ API & Aprox. 5 & 2.71 \\
\hline Mahantango Shale & $<200$ API & N/A & $>2.55$ \\
\hline Tully Limestone & Clean (30 - 110 API) & Aprox. 5 & 2.71 \\
\hline Harrell Shale & $>200$ API & N/A & $<2.55$ \\
\hline
\end{tabular}

Table 1-1. Lithostratigraphic criterion used to correlate the well logs in the sub-surface in West Virginia and southwestern Pennsylvania (Boyce and others, submitted). 


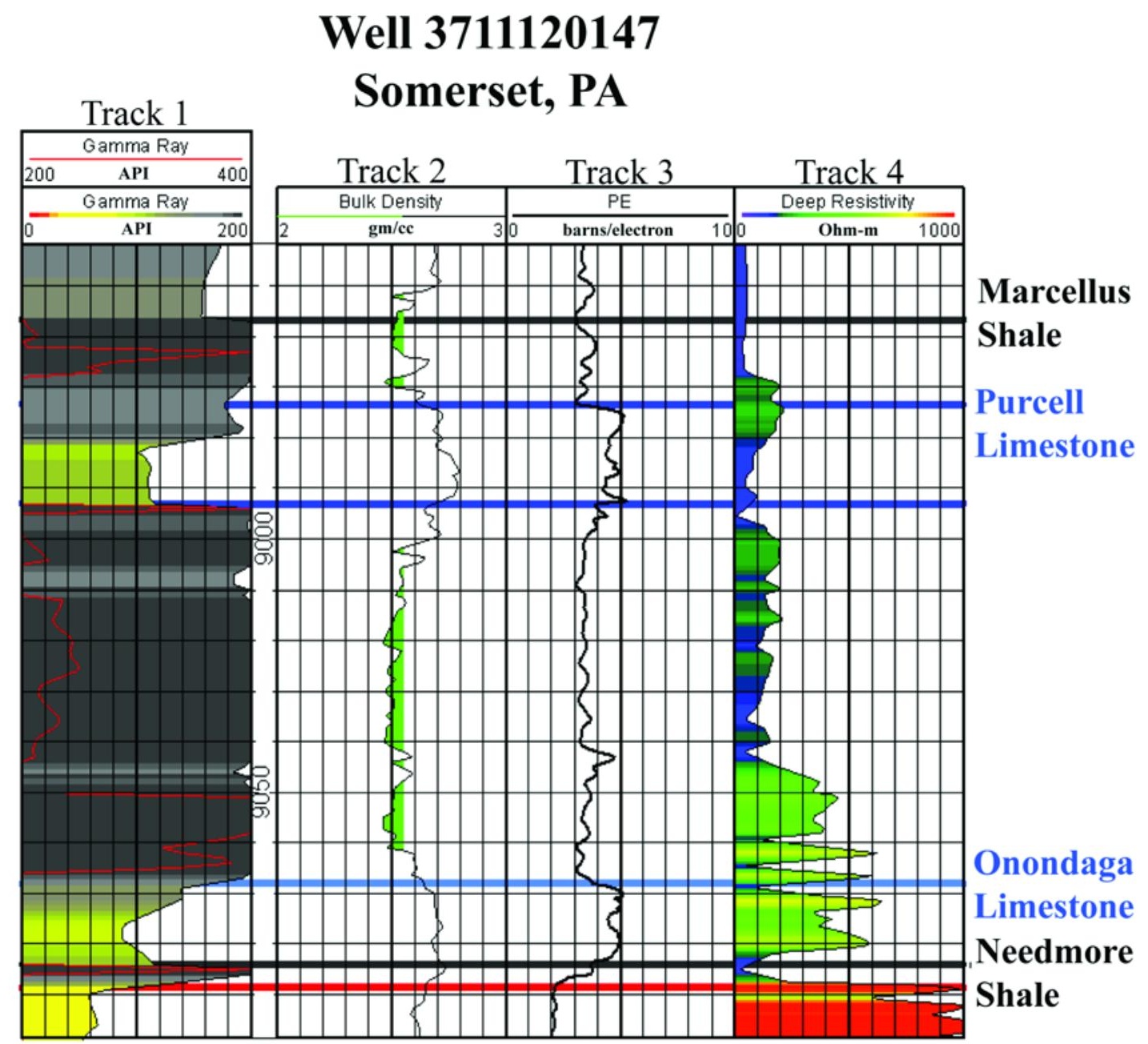

Figure 1-3. Type log for the Marcellus, Purcell, Onondaga, and Needmore units in southwest Pennsylvania and West Virginia (Boyce and others, submitted). The gamma ray curve is plotted on Track 1 and ranges from 0 - 200 API. When the gamma ray exceeds 200 API it wraps around and is outlined in red. The bulk density is plotted in Track 2 and is shaded green for bulk density values less than $2.55 \mathrm{~g} / \mathrm{cc}$. The photo electric (PE) curve is plotted on Track 3 and ranges from $0-10$ barns/electron. The resistivity curve is plotted in Track 4 and is scaled from 0 to 1000 Ohm-m's. The warmer colors for the resistivity curve represent higher values and the colder colors represent the lower values. 


\section{Well 4704105144 \\ Lewis County, WV}

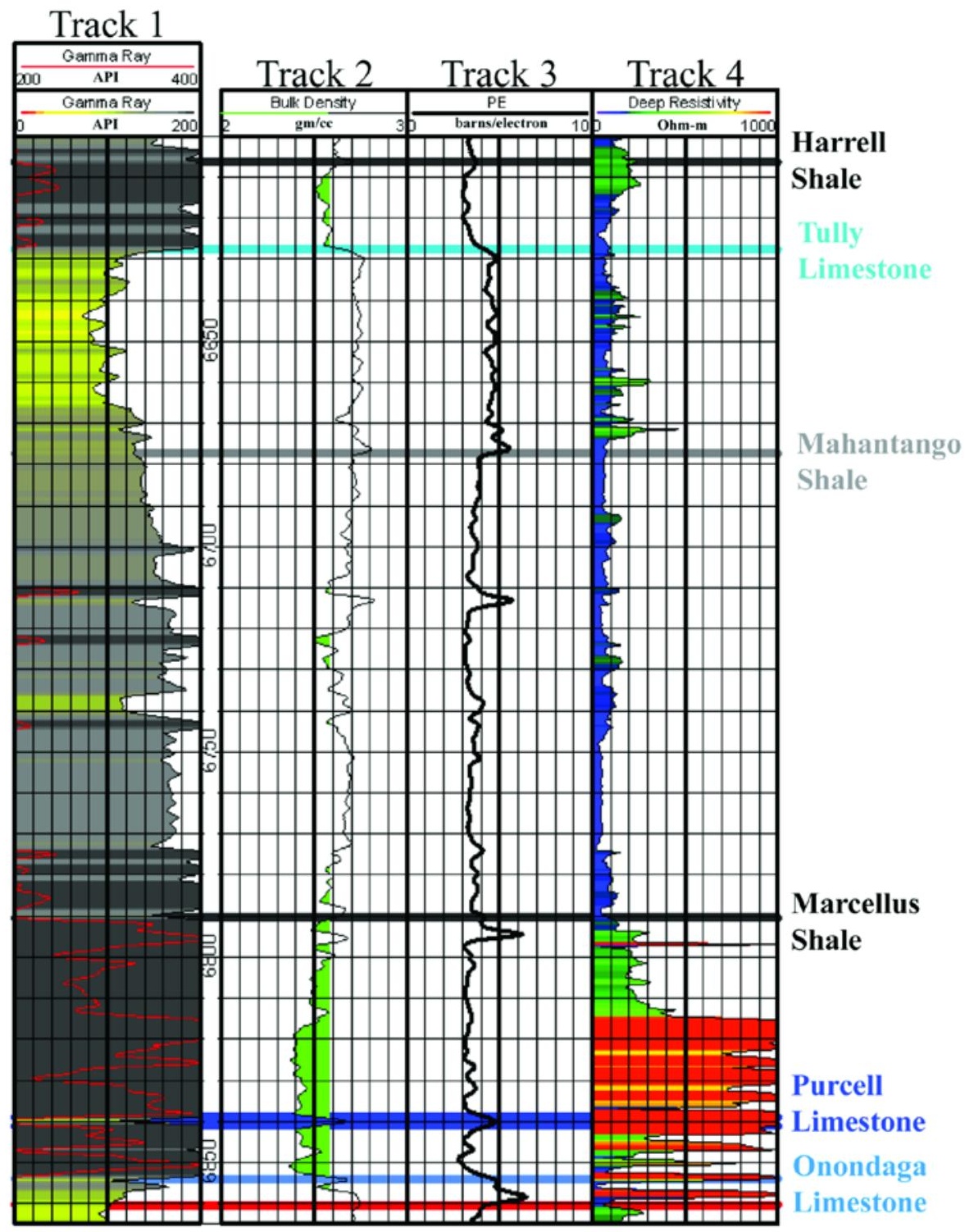

Figure 1-4. Type log for the entire Middle Devonian interval for the study area in southwest Pennsylvania and West Virginia (Boyce and others, submitted). The gamma ray curve is plotted on Track 1 and ranges from $0-200$ API. When the gamma ray exceeds 200 API it wraps around and is outlined in red. The bulk density is plotted in Track 2 and is shaded green for bulk density values less than $2.55 \mathrm{~g} / \mathrm{cc}$. The photo electric (PE) curve is plotted on Track 3 and ranges from $0-10$ barns/electron. the resistivity curve is plotted in Track 4 and is scaled from 0 to $1000 \mathrm{Ohm}-\mathrm{m}$. The warmer colors for the resistivity curve represent higher values and the colder colors represent the lower values. 


\subsection{WELL LOG ANALYSIS}

In order to evaluate the accuracy of the well log predictions of reservoir properties the wireline logs were compared to the core analysis to account for components that can affect the tool readings (i.e. pyrite and TOC). A valuable tool used in well log analysis is the bulk density (RHOB), because of its sensitivity to changes in lithologic components and fluids occupying the pores. The RHOB tool's sensitivity to rock density allows for an overall estimation of porosity in a reservoir. Heavier minerals, such as pyrite affect the RHOB readings by making the reservoir matrix denser than the standard (normally quartz in the Appalachian basin), and consequently giving the appearance of reduced porosity. Gas present in a reservoir pores or bound to the matrix will make the reservoir appear lighter in overall density than a fluid standard, potentially overestimating porosity. The over estimation of porosity is especially true in gas-shale units such as the Marcellus that yield high volumes of gas in place, due to free gas in porosity plus adsorbed gas related to the high initial TOC content. In addition, the pad-based density tool can be severely affected by in a rugose borehole where the density recorded is influenced by the density of the drilling medium (fluid or air). The presence of wash-out intervals is common condition in shale units that can be easily checked with the caliper log.

Core data displays an overall positive relationship between the content of pyrite and TOC (Figure 1-5). Shale units, such as the Marcellus, have been theorized to have been deposited in overall reducing conditions (Demaison and Moore, 1980). A byproduct

of the breakdown of organic material in reducing conditions is hydrogen sulfide, which in a post-depositional setting excess iron in pore waters will readily bind to the sulfides, creating large amounts of pyrite (Demaison and Moore, 1980). When TOC measured in 
core sample is compared to the density measured by the RHOB tool there is an overall increase in density associated with a decrease in the concentration of TOC (Figure 6). This trend illustrates that the more TOC present in the rock the lighter it will appear (i.e. more porous) due to increased bound gas content and to the lower density of kerogen. Interestingly, when the pyrite is compared to the density measured by the RHOB tool, we found no relationship (Figure 1-7). This indicates that even though the pyrite should positively affect the density, the density measured by the RHOB tool is negatively affected by the increased concentration of lower density organic material in the rock matrix, as well as free and adsorbed gas in the Marcellus Shale. 


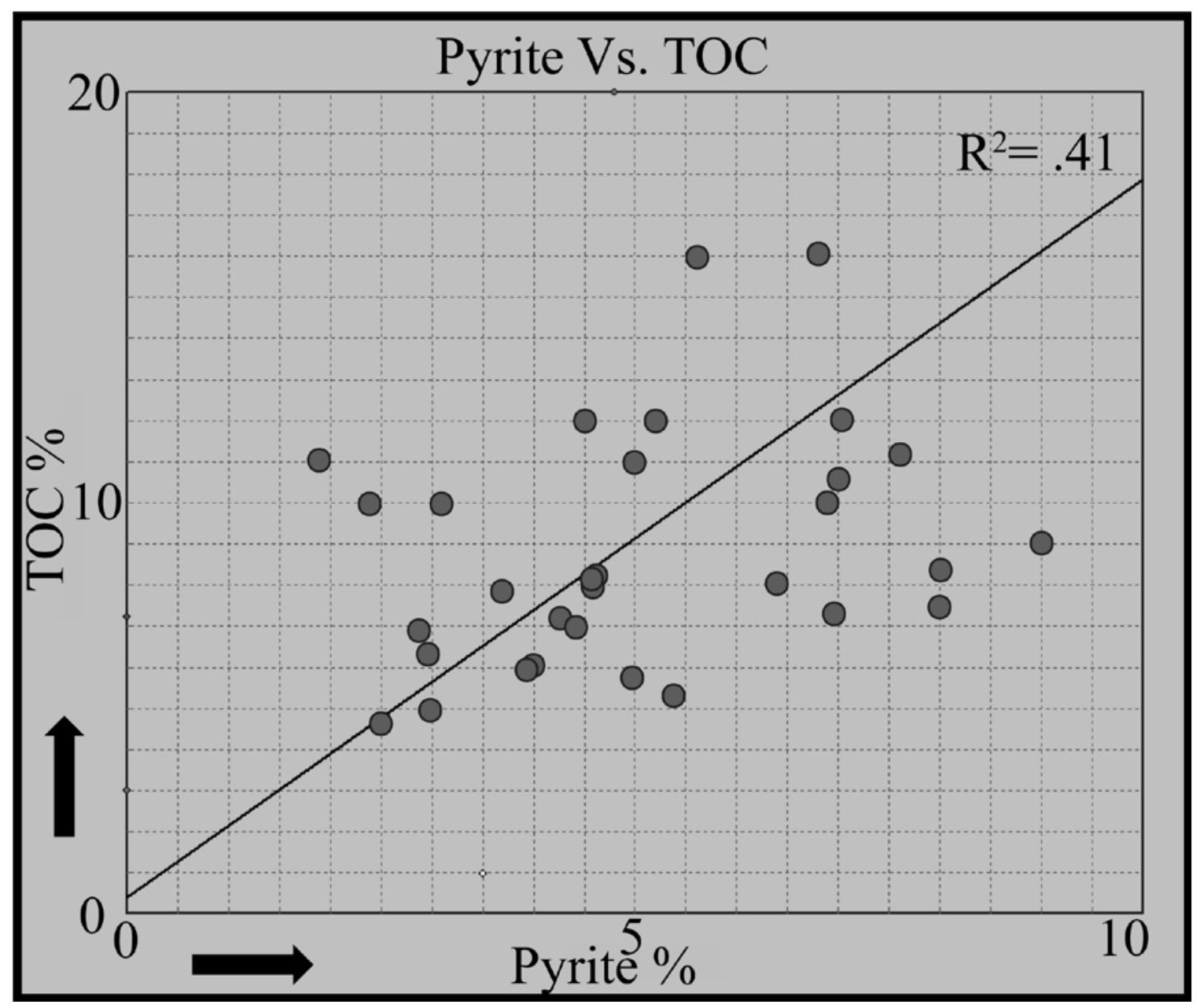

Figure 1-5. Plot illustrating the positive relationship between total organic carbon (TOC) and pyrite from core samples. 


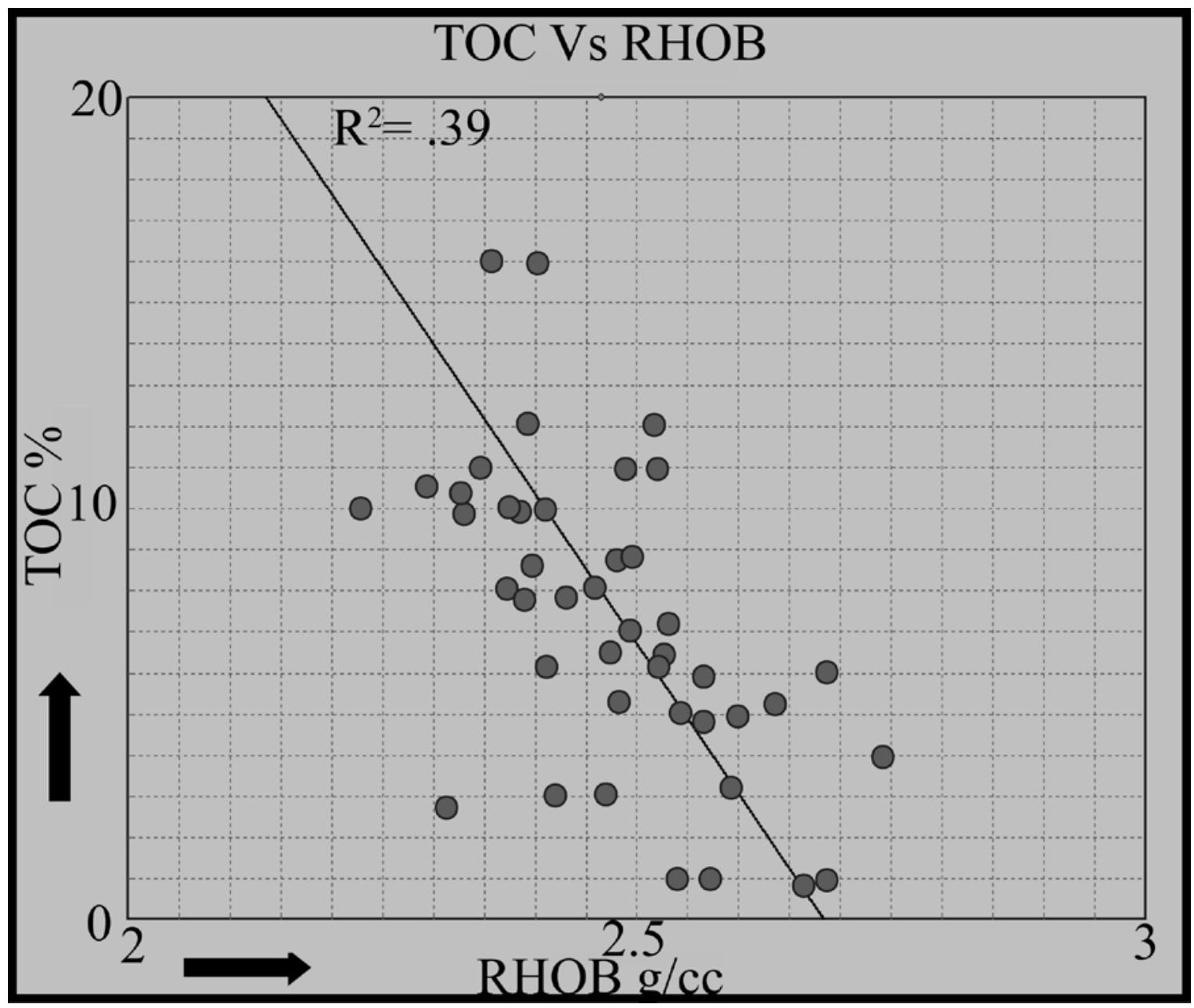

Figure 1-6. Plot illustrating the negative relationship between total organic carbon (TOC) from core samples and bulk density log data (RHOB). 


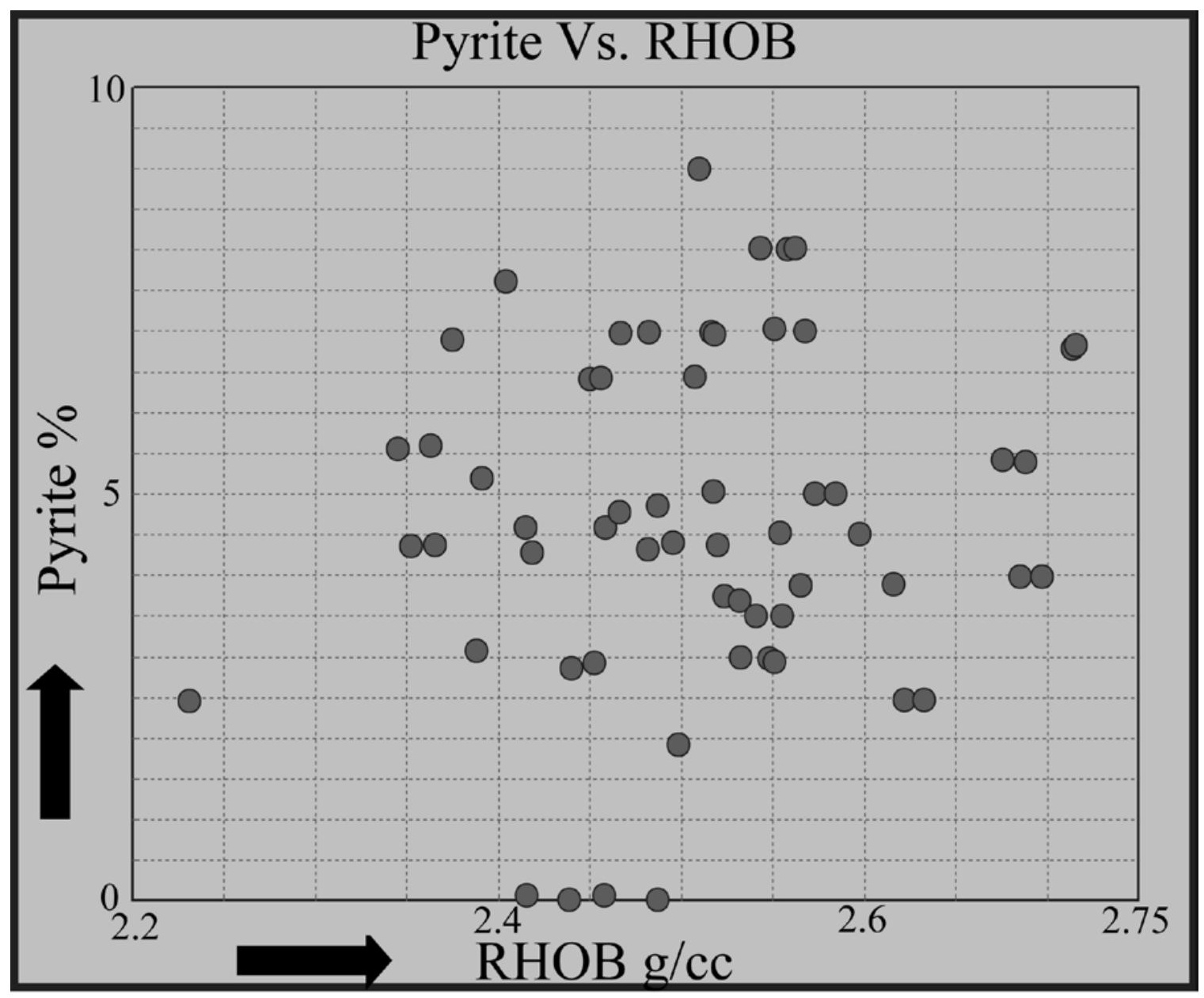

Figure 1-7. Plot illustrating the absence of a relationship between pyrite from core samples and bulk density well log data (RHOB).

\subsection{Spectral Well Logs}

The spectral gamma ray log can be a very valuable tool in analysis of shale-gas units and is often underutilized in conventional and unconventional plays. The gammaray spectral logging tool measures the abundance of the three most common naturally occurring radioactive elements, thorium (Th), uranium (U), and potassium (K). When compared to the core analysis, we found distinct trends that can be associated with the spectral logs. 
We found that an increase in the Th content, as measured by the spectral log, was positively related to an increase in the amount of illite measured in core samples (Figure 1-8). Also, the thorium content was related to a decrease in quartz content (Figure 1-9). These relationships are believed to be related to the insoluble nature of $\mathrm{Th}^{4+}$ under both reducing and oxidizing conditions. Thorium in the Marcellus Shale is believed to be bonded to the clay films or incorporated in the clay matrix. The clays may have been derived from thorium-rich feldspars. The relationship between Th content, and clay content can be extrapolated further by comparing the Th content as measured by the spectral to the deep resistivity curve (RESD) (Figure 1-10). In reservoirs such as the Marcellus, the clay content can suppress the resistivity of the rock because of the association with the bound water on clay films. Therefore, it may be possible to regionally predict clay/quartz content for the Marcellus using a logarithmic regression of the RESD curve to predict Th content. Improved identification of clay content regionally, and within a single well bore, could target areas and zones of reduced illite content that would be more amenable to fracture stimulation (i.e. less Th).

Similar to the analysis performed with the Th and RESD curve, a relationship is observed between the uranium content as measured by the spectral log (U) and the total gamma-radiation measured by the standard gamma ray log (SGR) (Figure 1-11). Previous studies have observed a link between U concentration and TOC (Beers, 1945; Swanson, 1960; Passey and others, 1990). A correlation of higher gamma-ray intensity and in particular the concentration of uranium (U), to increased amounts of TOC in the Marcellus and related Middle Devonian units has been observed (Schmoker, 1981; Fertl and Rieke, 1980; Boyce and Carr, 2009). The relationship appears to hold throughout the 
study area and provides a proxy to quantify areas of increased TOC accumulation. Although the spectral gamma ray tool is a extremely usefully tool, it is not run as common practice in wells targeting the Middle Devonian shale units in the Appalachian basin. Using the fifteen available spectral gamma-ray logs scattered across the study area, a relationship was developed for measured uranium (ppm) and the standard full-spectrum gamma ray (API). The relationship between the two curves is polynomial and the uranium values can be calculated using the standard gamma ray within a ten percent error (Figure 1-11). Considering the tie between TOC in place and gas content in the Marcellus the estimated uranium content from the standard gamma ray log can be used to evaluate the gas potential on a regional or local basis (Figure 1-11).

The spectral gamma ray curves have been used to determine the $\mathrm{Th} / \mathrm{K}$ ratio as a means to identify clay types (Adams and Weaver, 1958). Clay typing can be important in unconventional shale plays because some clay types (i.e. smectite or montmorillonite) have the tendency to swell when saturated with water, which can affect the effectiveness of fracture stimulation and cause problems during flowback of fracture fluids or in production. A log plot of the $\mathrm{Th} / \mathrm{K}$ ratio illustrates that the clay found in the Marcellus Shale in the examined well is primarily illite with only a few thin smectite-rich intervals (Figure 1-12, Track 2). The dominance of illite is confirmed by the XRD results (Boyce and others, submitted). The $\mathrm{Th} / \mathrm{K}$ ratio method can be used for other wells in the region. Ash beds in the Marcellus Shale such as the Tioga Ash Bed however small can be identified by an increase in the $\mathrm{Th} / \mathrm{K}$ ratio and would appear to be smectite rich.

Another useful ratio that can be derived from the spectral gamma-ray suite is the Th/U ratio to indicate redox potential during deposition (Adams and Weaver, 1958). The 
ratio's tie to redox conditions is dependent on the relative solubility of uranium during deposition under oxidizing conditions. It has been suggested that when the ratio is less than two (i.e. relatively U-rich), reducing conditions were dominant, and when the ratio is greater than seven (i.e. relatively $\mathrm{U}$ poor) conditions were more favorable for oxidizing environments (Adams and Weaver, 1958). This method was applied to the Marcellus interval and the results illustrate cyclic intervals of relatively oxidizing (oxic) and reducing (anoxic) environments (Figure 1-12, Track 3). 


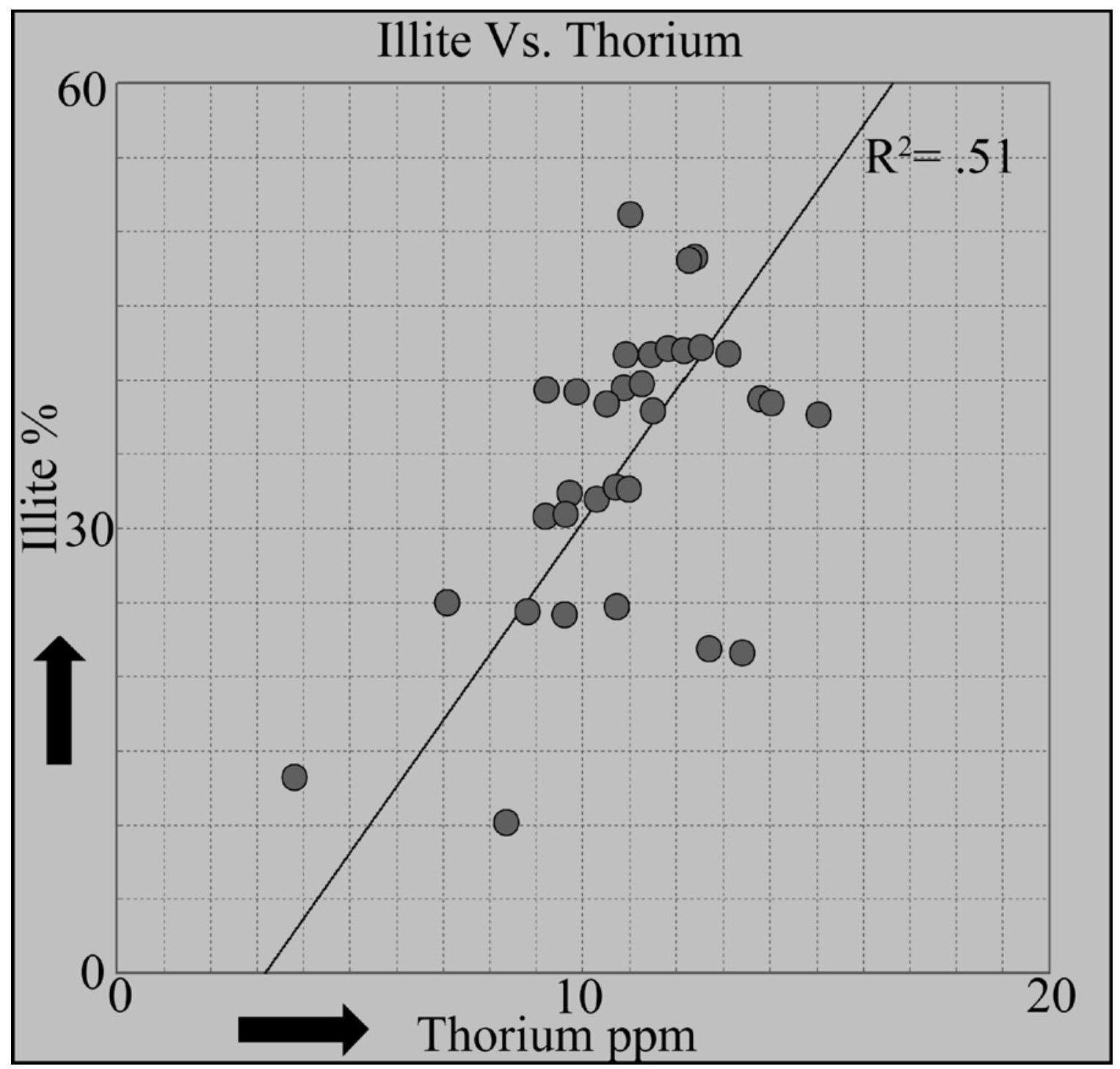

Figure 1-8. Plot illustrating the relationship between the measured illite percentages obtained from core data and the thorium (Th) content (ppm) obtained from the spectral log. As illite concentration increases so does thorium, showing the positive relationship between the thorium (Th) curve and clay content. 


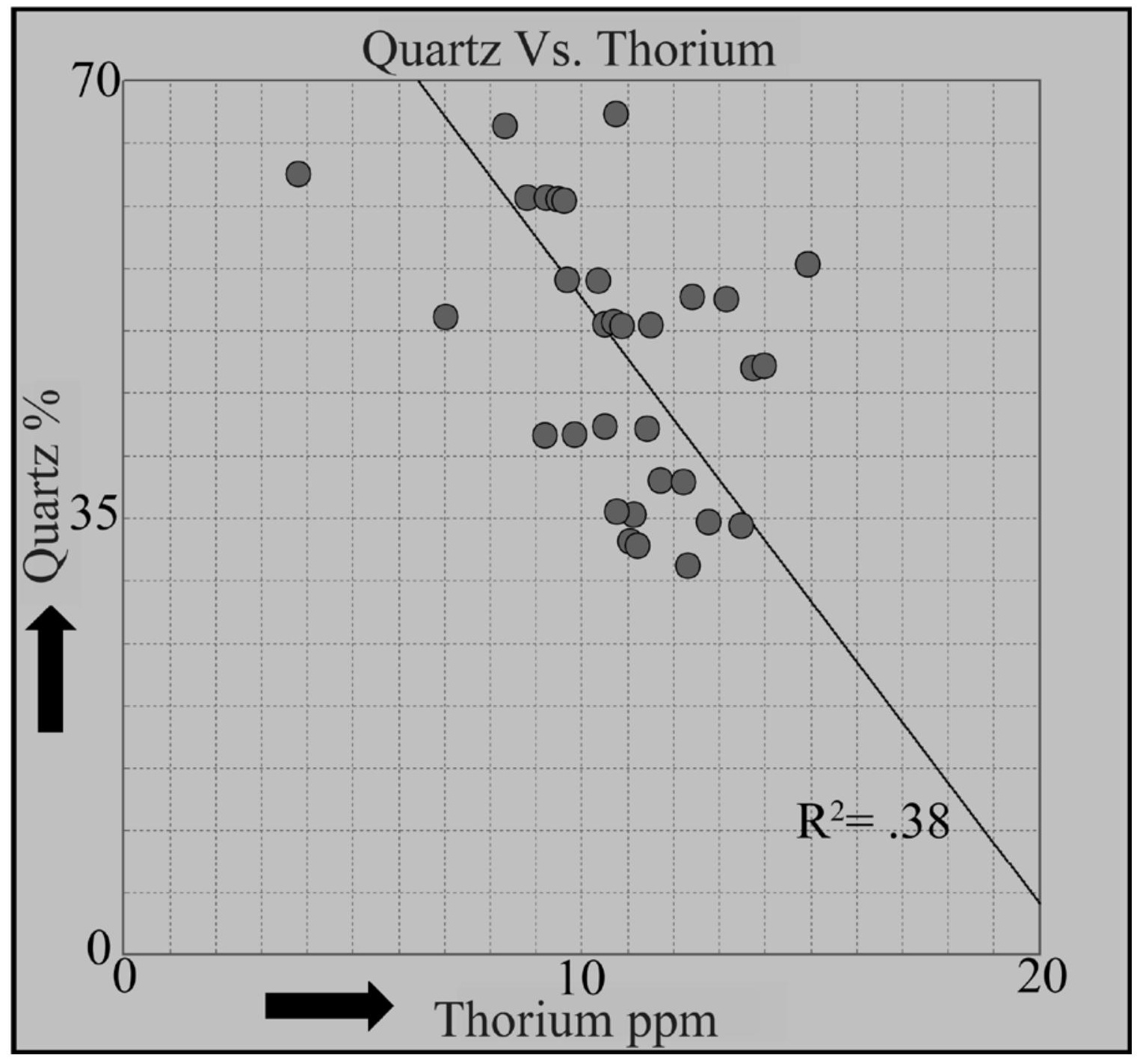

Figure 1-9. Plot illustrating the negative relationship between quartz percentages obtained from core data and the thorium (Th) content (ppm) obtained from the spectral log. As quartz content decreases the thorium (Th) log increases. 


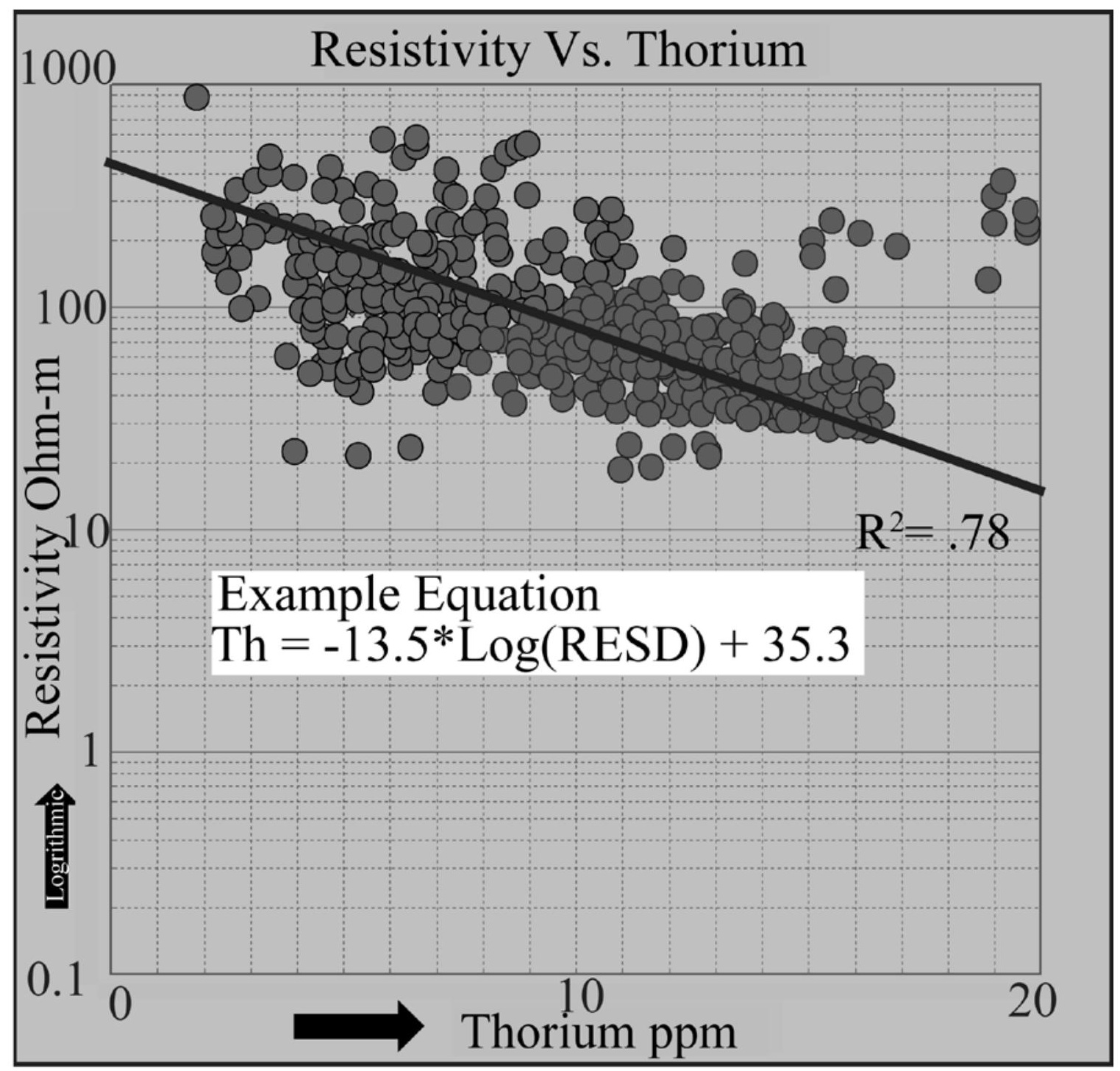

Figure 1-10. Plot illustrating the relationship between the resistivity curve and the thorium (Th) concentration (ppm) as measured by the spectral gamma ray log. As resistivity decreases logarithmically, thorium (Th) concentration increases. The thorium (Th) decrease with resistivity is interpreted as the result of the bound water associated with films on relatively thorium-rich clay. 


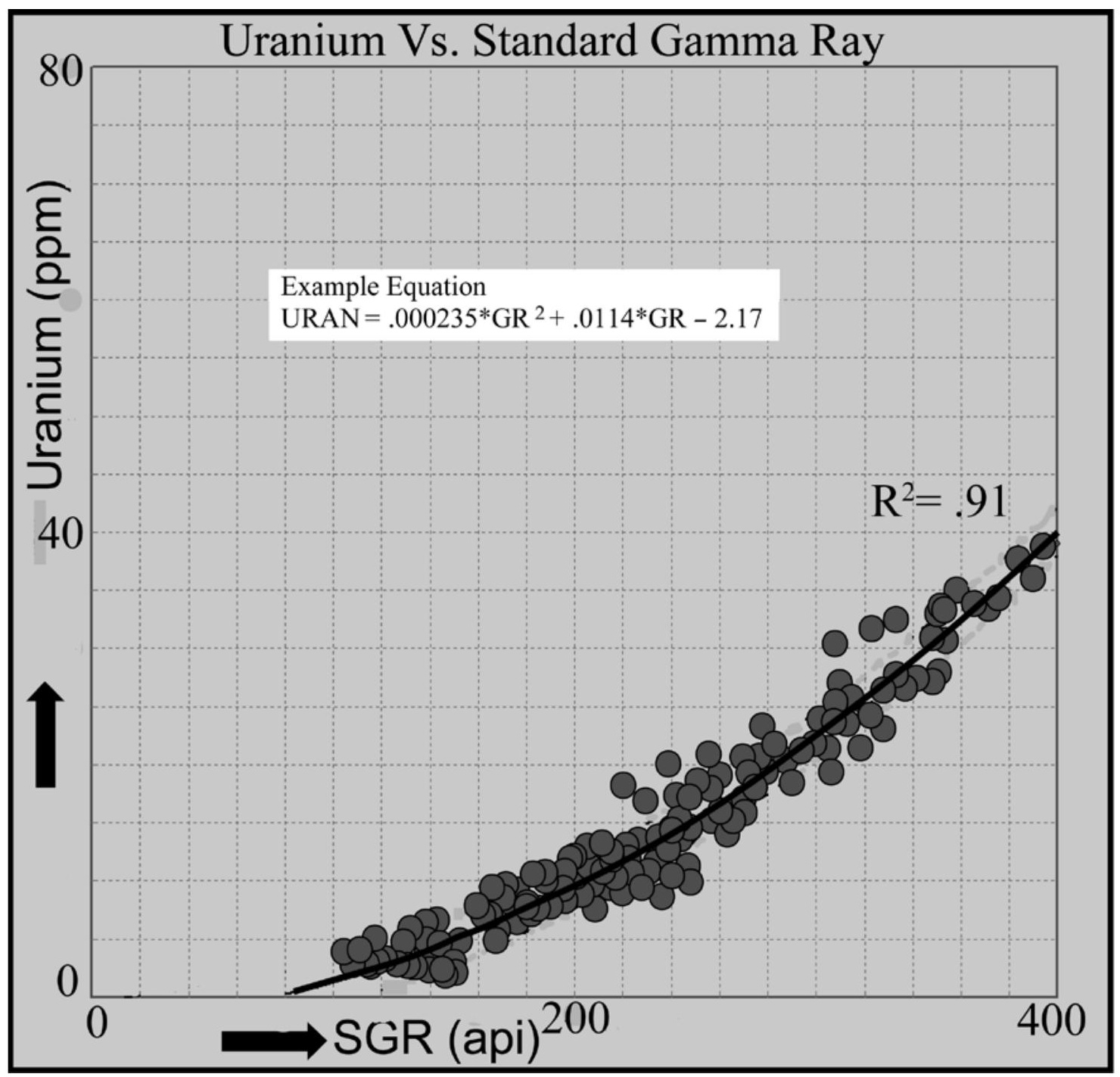

Figure 1-11. Plot of the uranium (U) concentration (ppm) derived from the spectral gamma ray log against the standard gamma ray (SGR in API units) (Boyce and others, submitted). An increase in $U$ concentration can be predicted by an increase in the SGR using a polynomial equation. In the Marcellus of the central Appalachian basin, $U$ concentration can be estimated and extrapolated spatially from the limited spectral logs using the abundant SGR logs. 


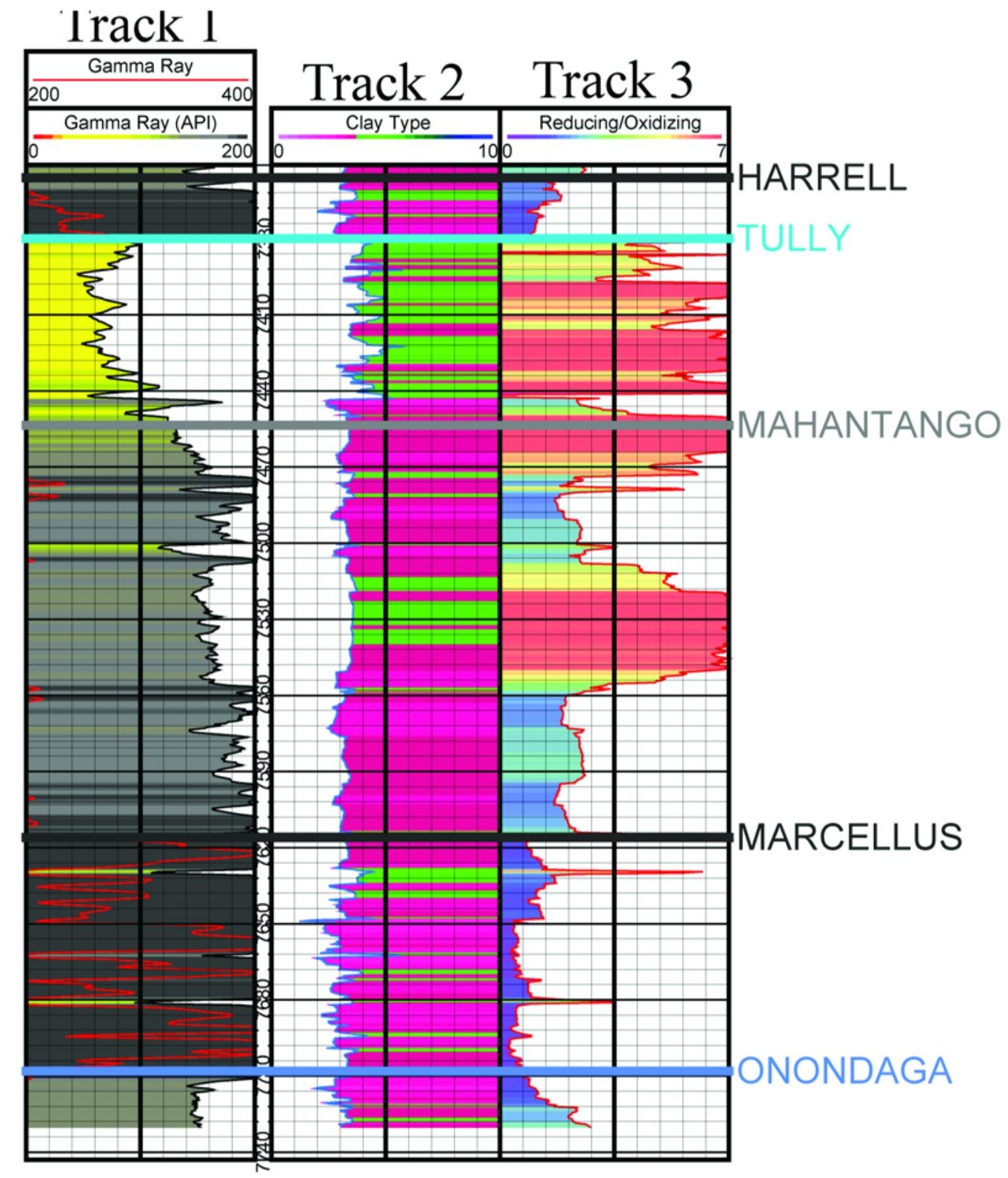

Figure 1-12. Well log illustrating two generated curves from the spectral gamma ray log to predict redox conditions and clay type. Track 2 is the ratio of thorium (Th) to potassium $(\mathrm{K})$, which is used to estimate clay type. When the track is shaded pink $(<3.5)$ the clay is illite-rich and when the curve is green $(>3.5)$ the clay will be enriched in smectite or mixed-layered clays. Track 3 is the ratio of thorium (Th) to uranium (U), which provides an indication of redox conditions during deposition. As the ratio increases the depositional environment was more oxic (warmer colors) and as the ratio decreases redox conditions moved to a more reducing state (cooler colors). The redox curve illustrates the cyclic nature of oxidizing versus reducing conditions in the Middle Devonian interval. 


\subsection{Total Organic Carbon Prediction}

The estimate of TOC content in shale-gas units such as the Marcellus is an important parameter to evaluate gas potential on a local and regional basis. Typically, TOC content is measured in core samples and estimated by developing a linear relationship between the bulk density (RHOB) and TOC content. The observed relationship of the TOC data from core samples versus the RHOB log data displayed a negative relationship between density and TOC content from core samples (Figure 1-6). From this relationship we were able to develop an equation to predict TOC using the RHOB curve (Figure 1-13, Track 2). However, the linear regression of the RHOB curve resulted in wide variations of predicted TOC, with error percentages averaging between 28 and 60 percent per well log (Figure 1-13, Track 2). This wide range in average error percentage is attributed to two factors: 1) The RHOB tool is affected by washout of the wellbore resulting in severe errors in the tool readings and consequently result in inaccurate TOC predictions; and 2) the tool is sensitive to fluid and gas in the pores and fractures, and as illustrated earlier the gas present in porosity can affect tool readings and potentially cause errors when trying to predict TOC. However, the RHOB tool is a sensitive tool and a commonly available log. Given favorable borehole conditions and increased TOC data from core to calibrate the tool, one could significantly improve predictive accuracy.

A relationship between a general increase in TOC and the Uranium (U) content as measured by the spectral gamma ray suite has been noted in the literature (e.g., Beers, 1945; Swanson, 1960; Passey and others, 1990). We examined this relationship in the Middle Devonian of the central Appalachian basin and observed a positive exponential 
relationship between TOC content measured from core data and the U concentration (ppm) derived from the spectral gamma ray log (Figure 1-14). However the U content, as measured by the spectral tool, does not have the vertical resolution and is not as sensitive to reservoir changes as the RHOB tool, the spectral tool does have an advantage in shale units prone to washout. As opposed to the density tool, the spectral gamma ray tool is not a pad tool and is significantly less affected by borehole conditions. Using a logarithmic regression of U content to predict TOC content resulted in a more consistent average of $20 \%$ error per well log (Figure 1-13, Track 3), as compared to the wider error range that results from using the RHOB curve (Figure 1-13, Track 2). In summary, a modest amount of TOC data can be used to calibrate the $\mathrm{U}$ content as measured by the spectral log and appears to provide more accurate prediction of TOC content than the density log under typical borehole conditions through shale intervals.

Using the fifteen available spectral gamma-ray logs scattered across the study area, a relationship was developed for measured uranium (ppm) and the standard fullspectrum gamma ray (API) (Figure 1-11). The relationship between the two curves was used to estimate $\mathrm{U}$ content for approximately 500 wells across the study area. The extrapolated $\mathrm{U}$ logs were input into the equation extracted from the relationship between $\mathrm{U}$ and TOC to make an estimate of TOC content (Figure 1-14). The interpreted TOC curves were used to create a net Marcellus isopach with TOC greater than seven percent (Figure 1-15). A distinct fairway is observed on the map that highlights the areas of relative thick high TOC content and possible increased gas potential. The distinct northsouth trend of inferred higher TOC content is interpreted as regional slope break 
favorable for enhanced organic production and accumulation (Boyce and others, submitted).

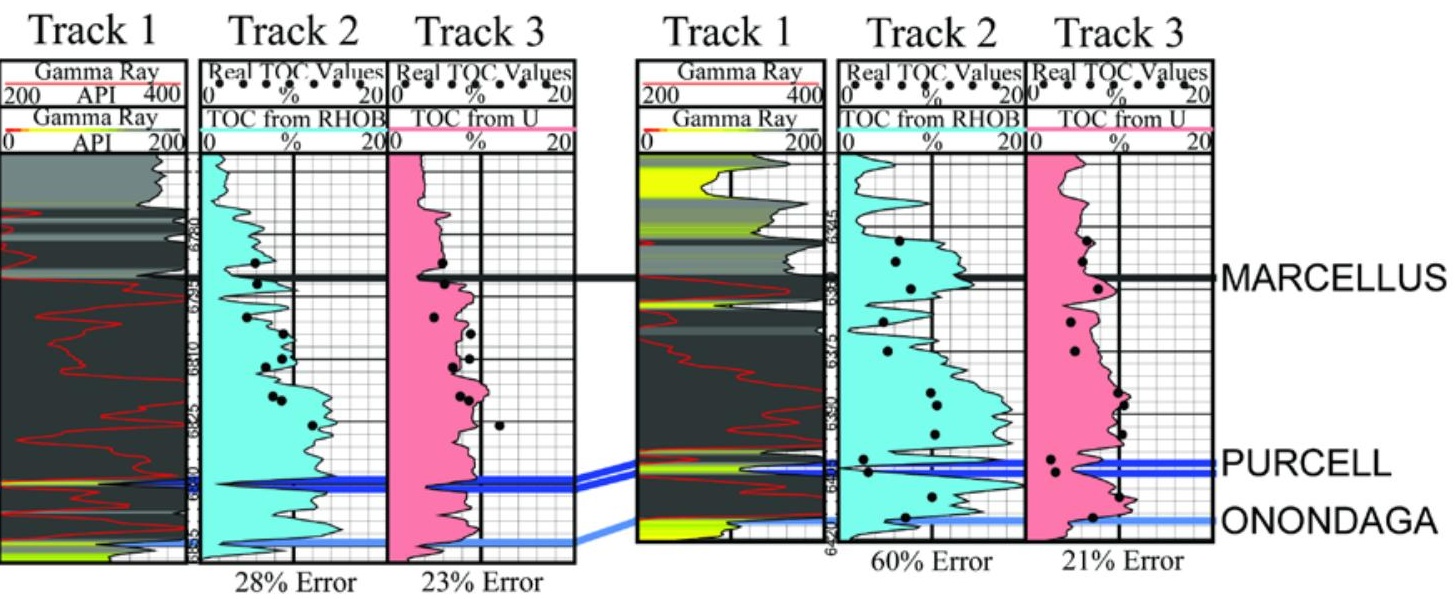

Figure 1-13. Illustration of two wells with core data used to calibrate the predicted total organic carbon (TOC) content from the bulk density (RHOB) and uranium (U) content (ppm) from the spectral log. Track 2 illustrates a method that was used to predict TOC from the RHOB curve using a linear relationship and then compared to the measured TOC data from core samples (black dots). Track 3 illustrates the method that was used to predict TOC from the U curve using a logarithmic relationship and then compared to the measured data TOC data from core samples (black dots). An average error percentage was taken for each curve in each well and is stated at the bottom of the track in each well log. It was found that on average, the logarithmic regression of the $\mathrm{U}$ content curve consistently improved the accuracy of predicted TOC content compared to using the density measurements from the RHOB curve. 


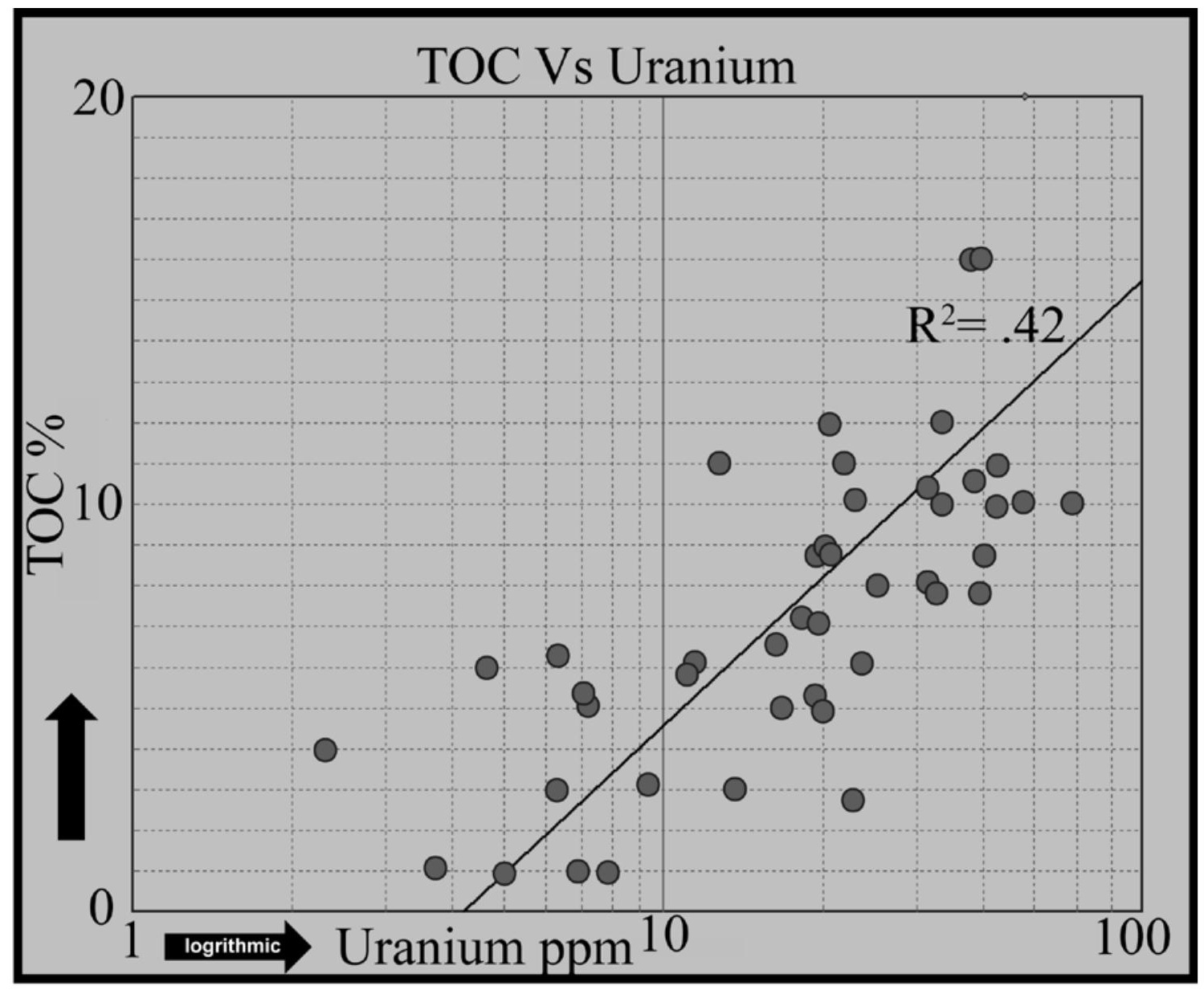

Figure 1-14. Plot of the measured total organic carbon (TOC) content (percent) measured from core data versus the uranium content (ppm) from the spectral log. The plot illustrates the positive exponential relationship of TOC and uranium. 


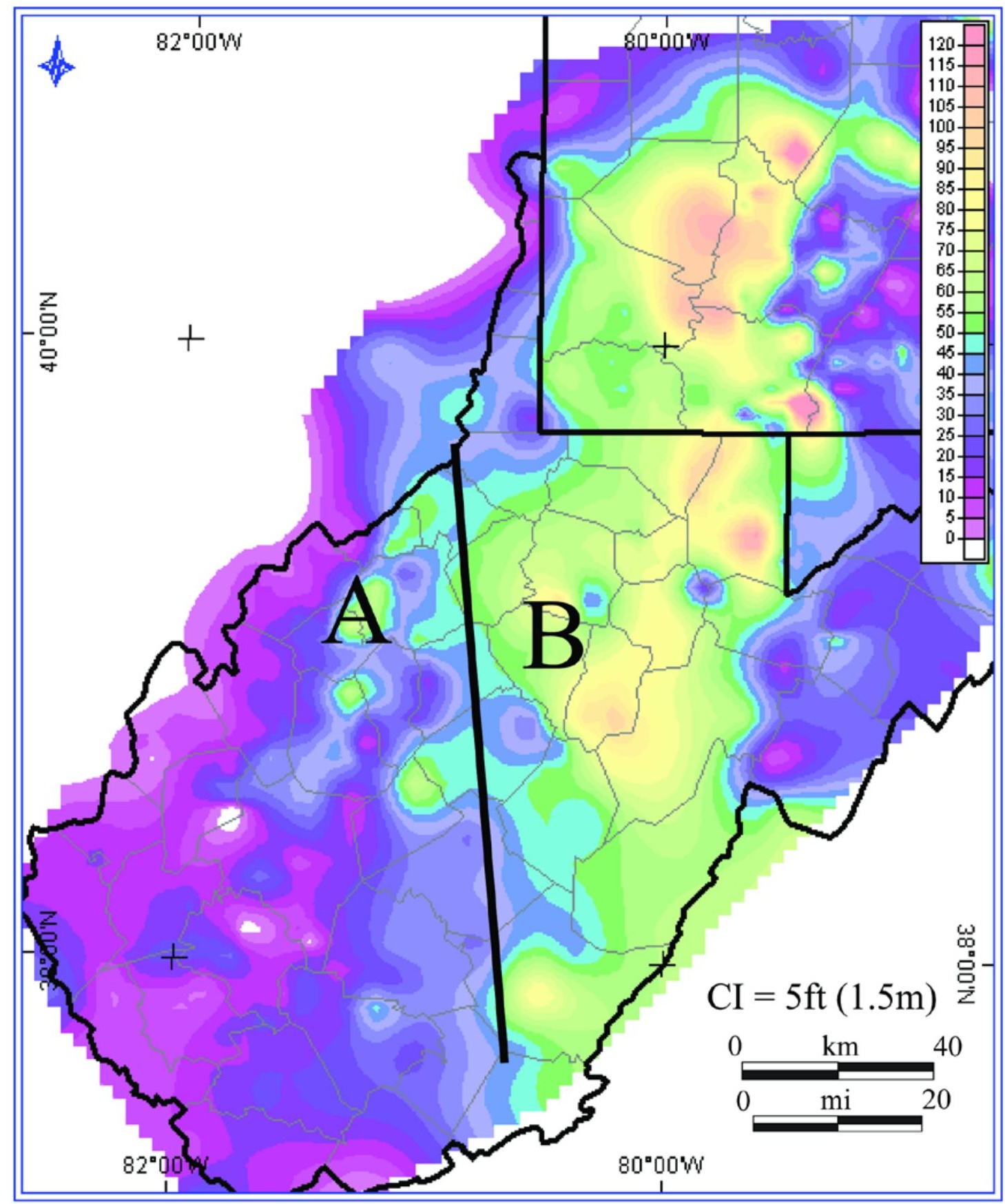

Figure 1-15. Interpreted organic richness of the Marcellus Shale illustrated by a map of net thickness of total organic carbon (TOC) content greater than or equal to $7 \%$. Contour interval is $5 \mathrm{ft}(1.5 \mathrm{~m})$. The trends of rapid change in thickness (A \& B) highlight areas that are interpreted to have been favorable for enhanced organic production and accumulation. These trends have been interpreted to be shelf break environments favorable for the production and accumulation of organic matter (Boyce and others, submitted). 


\subsection{Litholologic Identification}

An attempt was made to model the mineralogy of the Marcellus Shale by using the well logs in a RHOmaa-Umaa cross-plot calibrated to core data (Doveton, 1994). Umaa is calculated using the RHOB (bulk density), PE (photo electric), and PHIA (average porosity) curves (Eq1-1). RHOmaa is calculated using Equation 2 using the RHOB (bulk density) and PHIA (average porosity) curves (Eq1-2).

$($ Eq1-1) RHOmaa $=($ RHOB - PHIA $) /(1-$ PHIA $)$

$($ Eq1-2) Umaa $=(($ RHOB $*$ PE $)-$ PHIA $) /(1-$ PHIA $)$

The log data were calculated and plotted against the X-ray diffraction (XRD) data derived from core samples on the RHOmaa-Umaa plot. We found that there was a consistent shift from the core data to well log data moving up and to the right (Figure 116). Pyrite, a common constituent in the Marcellus shale samples, will pull the Umaa value to the right because of the large number of electrons associated with the iron in pyrite, increasing the PE value used in the Umaa equation (Eq1-2). 


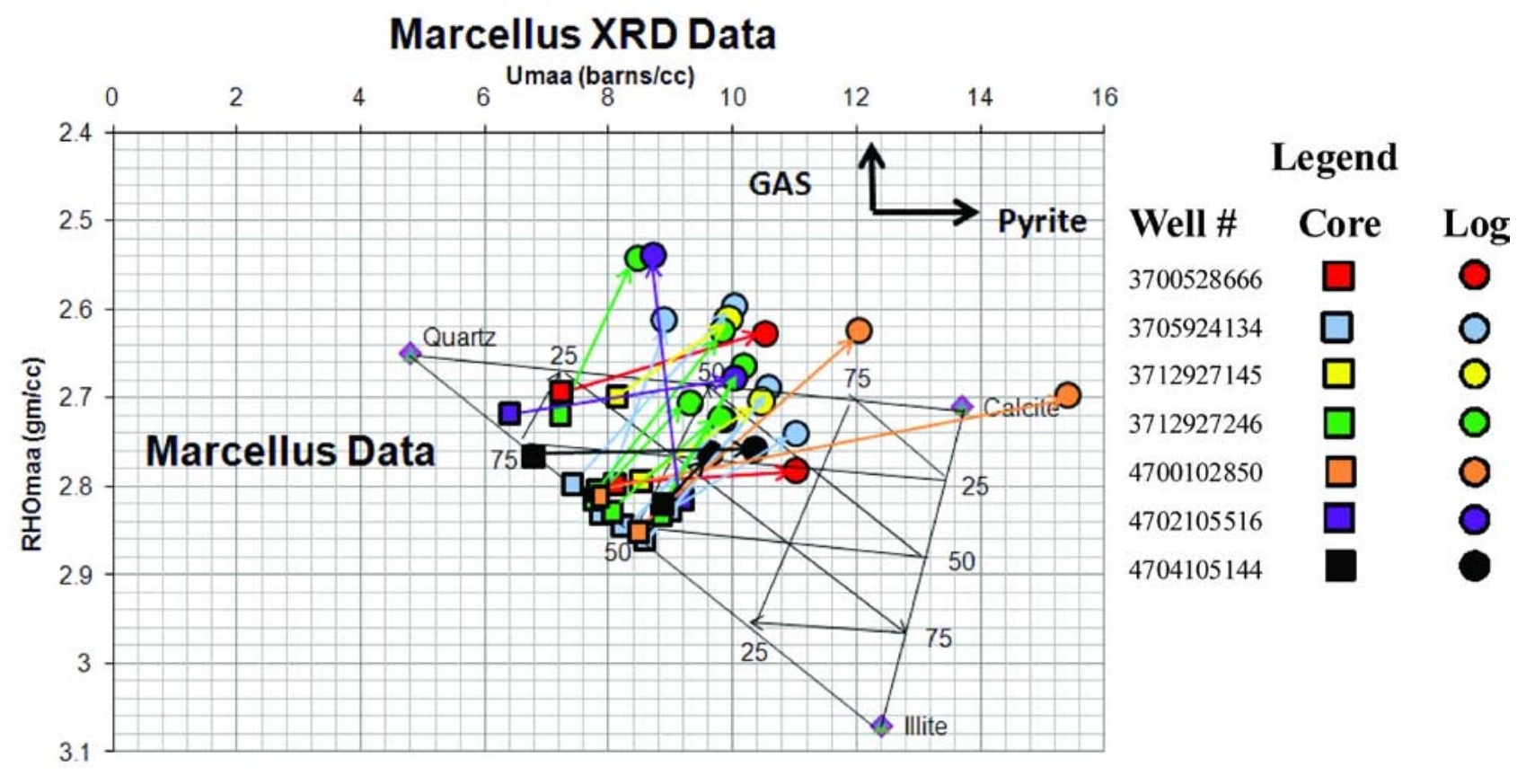

Figure 1-16. RHOmaa-Umaa plot is compared with X-ray diffraction (XRD) results for core sample of the Marcellus Shale (modified from Boyce and others submitted). The core samples (squares) plot on average on the quartz rich side of the mineralogical triangle, however the log data (circles) when plotted for the same sample is shifted up and to the right away from the quartz end member. The movement of corresponding log data to each core sample can be identified by the arrows illustrating the direction of movement. The movement to the right is caused by the higher number electrons associated with the iron in pyrite, and the upwards movement is interpreted as gas pulling the data above the lithologic triangle (low RHOmaa value due to the low density of gas or associated kerogen). The effect on these two components must be taken into consideration when identifying the lithology of the Marcellus, as well as using the well logs to identify gas rich zones.

Considering that it has been observed that the effect on the bulk density tool of TOC content and gas are offset by pyrite (Figures 1-16), it can be inferred that the offset in the Umaa equation is dominantly affect by PE tool picking up the pyrite content. This relationship can further be illustrated by plotting the pyrite versus the offset along the Umaa to the right (Figure 1-17). The plot shows that with increasing pyrite there is an increase in movement to the right. However, there are anomalous data points on this plot 
that do not correlate to the overall trend, which could possibly be tied to the increase in limestone content (Figure 1-17).

The lower bulk density values are interpreted to correlate to increases in low density gas content or kerogen in the reservoir, which affects primarily the RHOmaa value through both RHOB and PHIA (Eq1-1). As a result the RHOmaa value is pulled upwards from the core values on the mineralogical triangle (Figure 1-16). The severity of the influence that pyrite and gas (i.e. TOC) can have on the RHOB tool influences any lithologic analysis and would therefore need to be accounted for if attempting to develop a quantitative model for the Marcellus Shale. Given the relatively systematic offsets, it may be possible to develop a quantitative model to produce a robust lithologic solution using techniques such a neural net (Dubois and others, 2006, Qi and others, 2007). 


\section{Pyrite Vs. Umaa Movement To The Right}

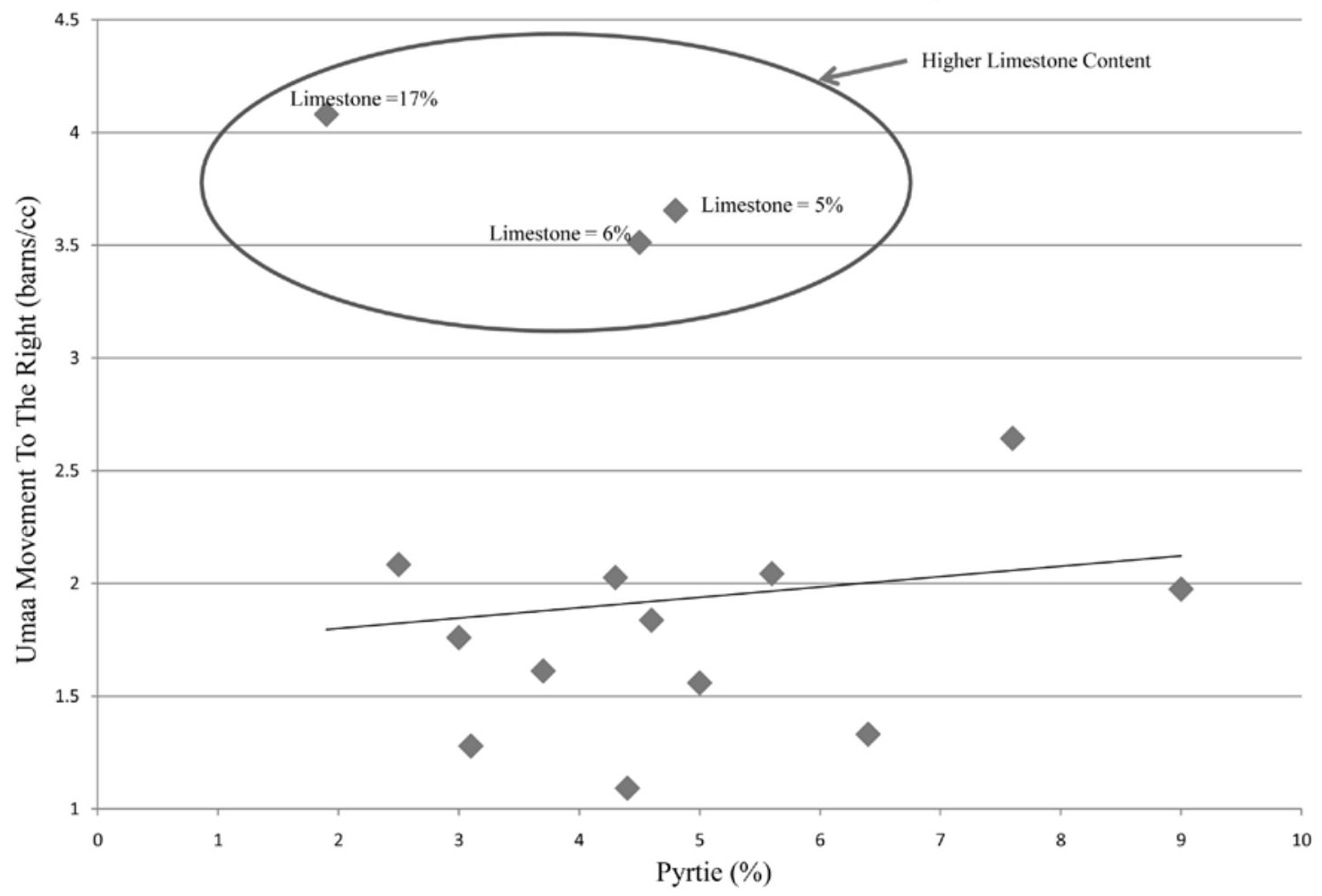

Figure 1-17. Plot illustrating the relationship between the percentage of pyrite and the movement to the right on the Umaa axis (Figure 1-16). The plot shows that as pyrite increases so does the movement to the right. There are several exceptions which have been highlighted on the plot that have extreme movements to the right on the Umaa axis.

\subsection{Spectral-Bulk Density Cross-Plot}

In the Marcellus, a relationship has been recognized for gas rich intervals between the standard gamma ray (SGR), the density porosity log and the TOC content (Ward, 2008). As observed, an increase in the SGR (API) was accompanied by an increase in TOC content. Specifically, the Uranium (U) component of the SGR correlated to an increase in TOC content. It was proposed that because of the high gas content, the density porosity would increase when more gas is present (over estimated porosity due to low density of the gas), and one could identify gas rich intervals in the Marcellus by assuming an initial one to one relationship between the SGR and density porosity (Ward, 2008). 
This approach was revised by using the estimated Uranium (U) content, derived from the spectral log, rather than the SGR log on the horizontal (x) axis (Figure 1-18). The Ucontent is believed to represent a better indicator of increased free or sorbed gas content related to abundant organic material (TOC). Second, we revised the assumption that the relationship between density porosity and the $\mathrm{U} \log$ is one to one. Density porosity is not a measurement of true porosity and therefore the relationship between $\mathrm{U}$ and density porosity is not necessarily one to one (i.e. an origin intercept on the cross-plot). We propose using the Tully Limestone as a proxy to determine the intercept of on the vertical axis (y). The Tully Limestone operates as a fracture barrier when the wells are treated and is not a gas producing interval. Using the average density porosity of the Tully as a proxy gives a more conservative and realistic relationship to the plot (Figure 1-18). Anything above the line, is considered to be gas rich and can used to highlight areas in the Middle Devonian shale units in the Appalachian basin. This particular plot illustrates the potential for gas-rich units in the Marcellus, Mahantango, and Harrell Shale. The Marcellus has numerous values with high $\mathrm{U}$ concentration (i.e. assumed rich in TOC content) plotting above the line. It is assumed that these points represent intervals that have a high potential for gas production. Also, the Mahantango and Harrell, while having lower U values (i.e. lower TOC), indicate potential for gas-rich zones (Figure 1-18). 


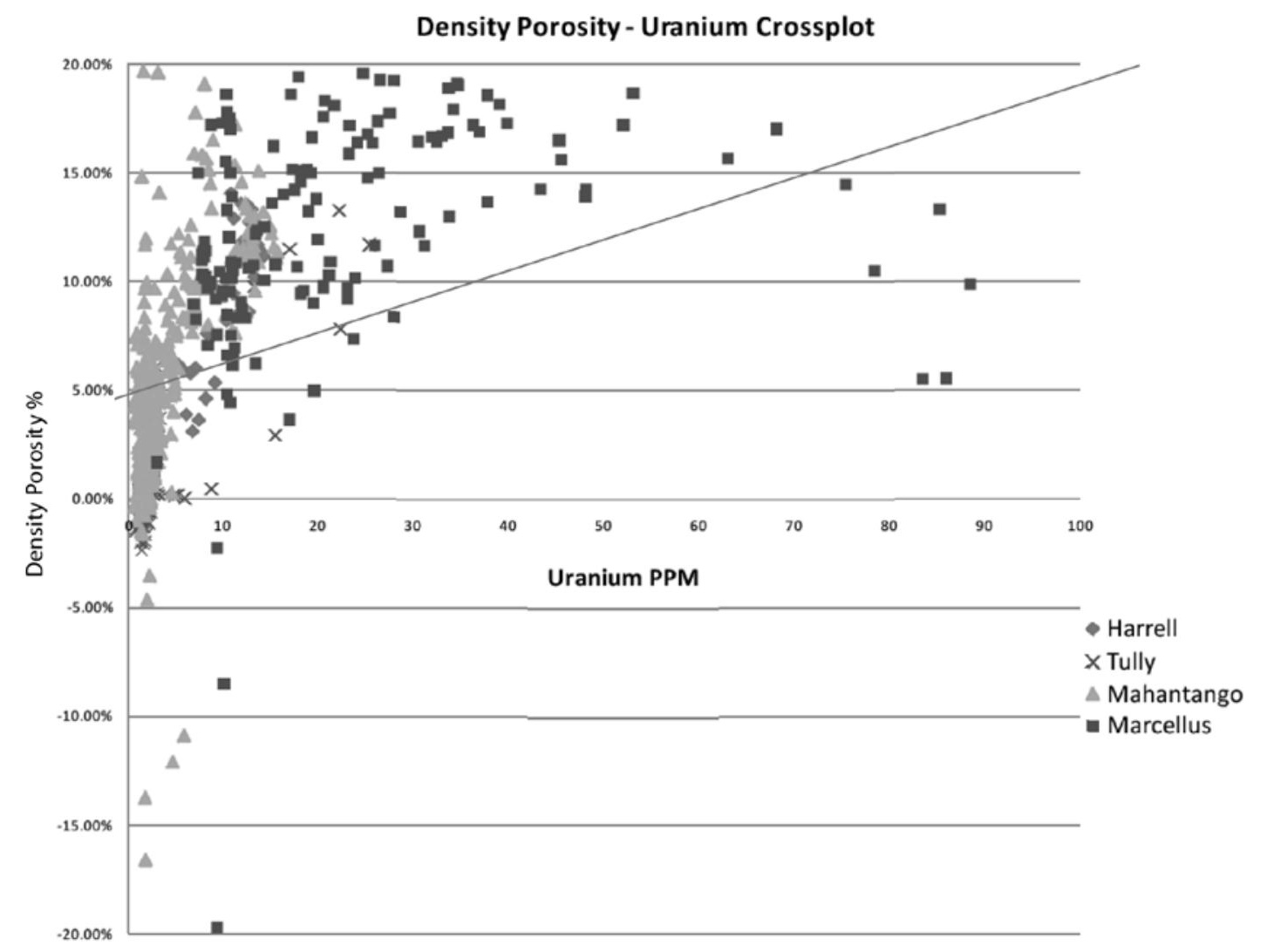

Figure 1-18. Cross-plot of uranium (U) in ppm versus density porosity. Anything above the line is considered to be free gas or sorbed gas to organic matter (Boyce and Carr, 2009).

\subsection{Gas Identification}

The use of the above mentioned U-density porosity cross plot is useful and can also be expressed in a well log. Two methods were attempted to express the relationship identified with the density-uranium cross plot (Figure 1-18). The first method is a basic expression on how to identify these gas rich zones in the interval for a well log by plotting the $U$ content (ppm) and the RHOB $\left(\mathrm{gm} / \mathrm{cm}^{3}\right)$ in the same track (Figure1-19, Track 2). Using appropriate scales, when the U exceeds the RHOB value, it is shaded green and highlights the area's most probable for gas production. The cross-over highlights thin intervals in Mahantango and Harrell shale units that may contain gas-rich 
targets that could enhance production. The second method used to express the relationship between the density porosity-uranium cross plot calculates the distance away from the trend line on the cross plot (Figure 1-18) that indicates gas rich intervals (Figure 1-19, Track 3). The greater the distance of the point from the line in the density porosityuranium cross-plot, may be an indicator of gas-rich intervals. The distance is generated using the point to line theorem. The equation for the line is computed in normal pointslope form as seen in Equation 3 (Eq1-3). The constants are designated as A, B, and C and the curves used are the density porosity (PHID) and uranium (U) curve. The equation is put into point slope form as seen in Equation 4 (Eq1-4). Finally the distance from the line (D) can be calculated by putting the constants from Equation 4 into Equation 5 (Eq15).

$$
\begin{aligned}
& (\text { Eq1-3) B*PHID }=A * U+C \\
& (\text { Eq1-4) B*PHID }-A * U-C=0 \\
& \left(\text { Eq1-5) D }=(A * U+P H I D * B+C) / \sqrt{ }\left(A^{2}+B^{2}\right)\right.
\end{aligned}
$$

The departure from the line distance (D) calculated above the line will be positive and below the line will be negative. When this is plotted in a well log we find it highlights areas that may have the greatest gas potential as well as areas potentially with higher volumes of gas (Figure 1-19, Track 3). We also compared the calculated value D was plotted versus the vertical difference between the calculated RHOmaa value from the log data and the plotted core data on the RHOmaa-Umaa cross-plot (Figure 1-20). There is a positive relationship between calculated value D vertical differences on the RHOmaa 
axis. This relationship supports the early interpretation of a gas effect on the RHOmaa values computed for the Marcellus Shale 


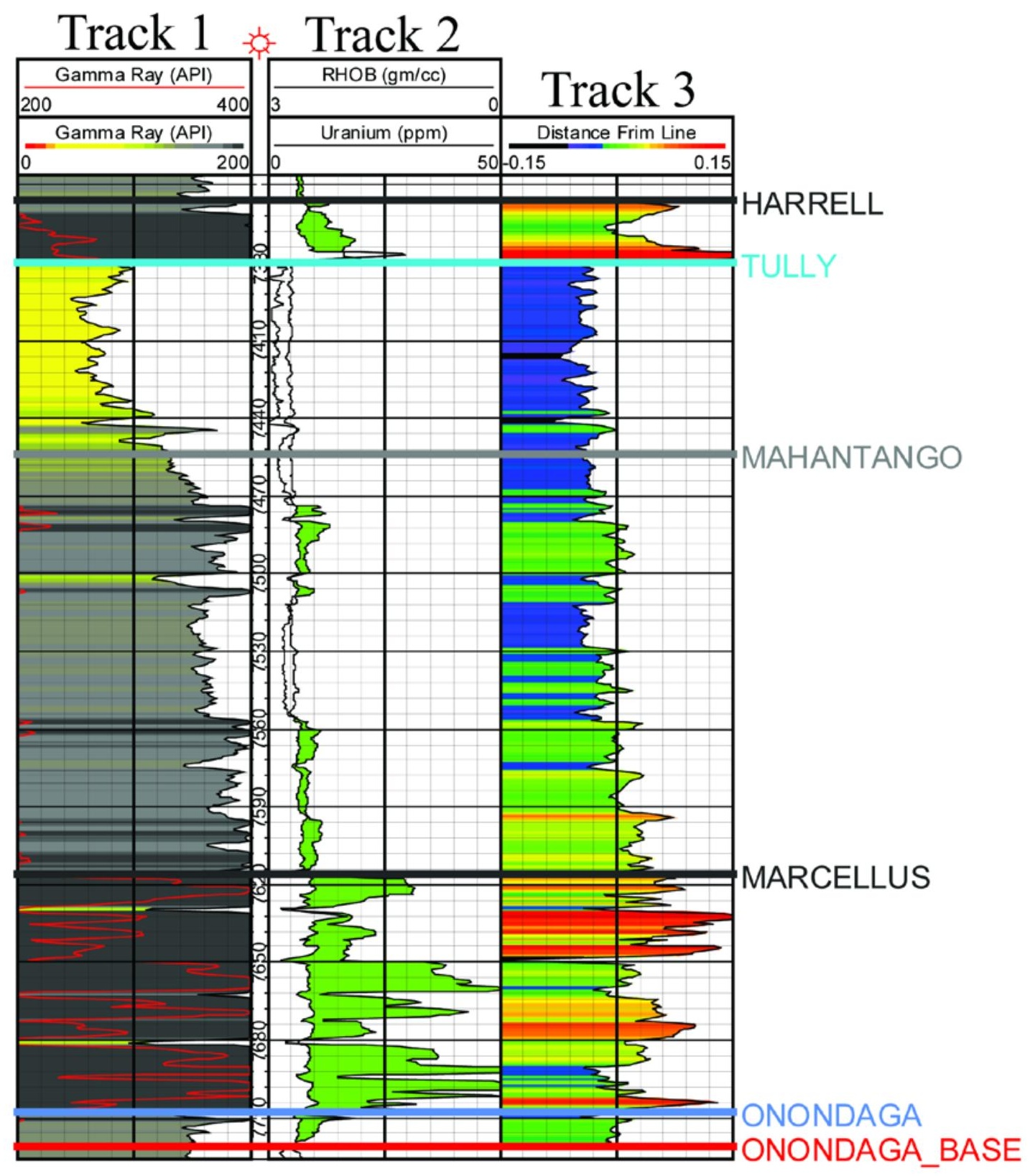

Figure 1-19. Log illustrating two methods of gas identification in the Middle Devonian of the Appalachian basin. Track 2 illustrates a method in which the uranium (U) content is plotted against the bulk density (RHOB) using an appropriate scale to highlight areas of high potential for gas-rich intervals. When the U curves exceeds the RHOB curve the cross-over is shaded green and highlights potential gas-rich intervals. Track 3 illustrates a method used to identify gas-rich intervals using the approximated line from the density porosity-uranium cross-plot (Figure 18). The point to line theorem was used to calculate the distance away from the line then plotted as a curve (D). Increased positive deviation from the line increased potential for gas-rich zones as well as possibly providing a relative quantification of potential gas volume. 
Distance (D) Vs. RHOmaa Movement Up

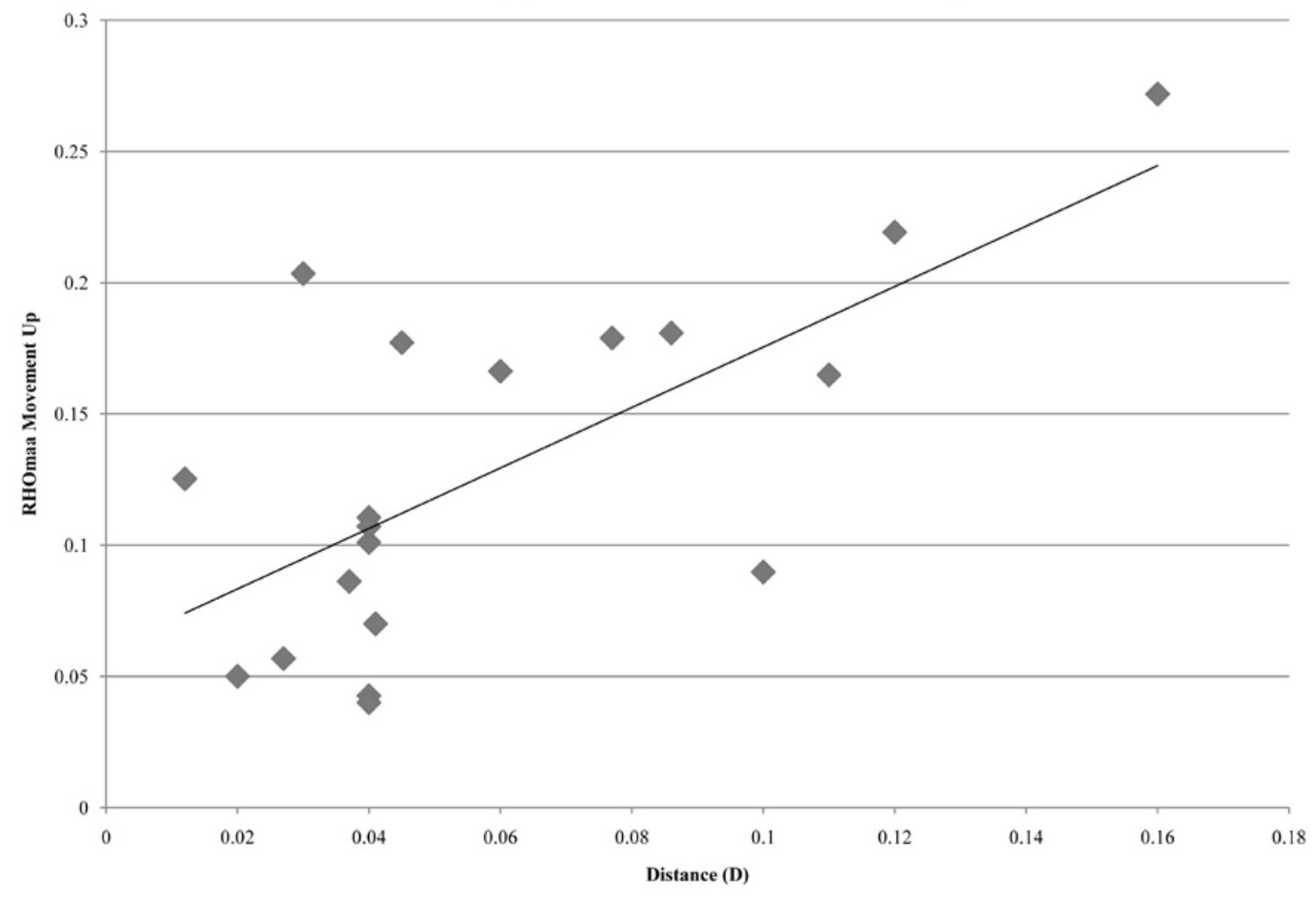

Figure 1-20. Plot of the distance away from the line on the density porosity-uranium cross-plot (Figure 18, 19) compared with the vertical difference between the calculated RHOmaa value from the log data and the plotted core data in the RHOmaa-Umaa cross plot (Figure 16). 


\subsection{Modified Water Saturation Calculations}

As discussed, the uranium (U) content derived from the spectral gamma ray log is believed to correlate to areas with high gas saturations in the Marcellus Shale and related Middle Devonian units. One can incorporate the $U$ curve into the water saturation calculations. Typically, Archie's water saturation equation is used to calculate the water saturation in a reservoir (Archie, 1947). It was originally derived for consolidated sandstone reservoirs as a result of empirical relationships observed between resistivity and porosity in variously cemented sandstone units (Archie, 1947) (Eq1-6).

$\left(\right.$ Eq1-6) $S_{\mathrm{w}}=\left(\left(\mathrm{R}_{\mathrm{w}} * \mathrm{a}\right) /\left(\Phi^{\mathrm{m}} * \mathrm{Rt}\right)\right)^{1 / \mathrm{n}}$

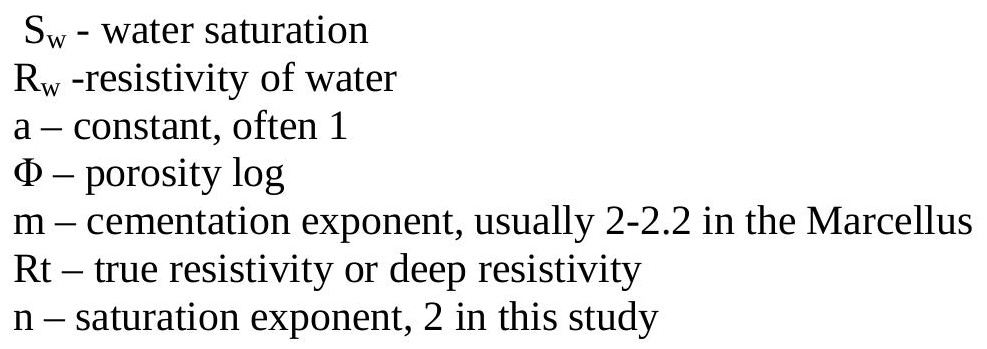

This relationship has stood the test of time and works well in sandstone units. However, the basic Archie equation was not intended, and is not accurate, for shale-rich units. This inaccuracy can be attributed to the bound water on the clay in shale units, such as the Marcellus. Bound water in the Marcellus Shale results in an overestimation of water saturation and underestimation of hydrocarbon saturation in a unit that produces negligible water (Figure 1-21, Track 2). Numerous approaches have been proposed for low resistivity hydrocarbon-rich units that compensate for thin bedded sand and shale units or dispersed shale (e.g., Passey and others, 2006). A relationship between gas content in the Marcellus Shale and the U was recognized by Boyce and Carr (2009). The U content was incorporated into a modified version of the Archie equation to reduce the 
water saturation in the shale (Figure 21, Track 3). Even though this modified equation lowers the water saturation for the interval to a more realistic value, the units do not balance. To solve this dimensionality problem, the thorium (Th) content can be incorporated into the equation (Eq 1-7). The Th concentration has a strong relationship to the clay content and low resistivity values (bound water), therefore when incorporated into the numerator it can account for the bound water (Figure 21, Track 4). Incorporating the Th concentration from the spectral gamma ray log into the numerator of the modified Archie equation (Eq 1-7) results in realistic water and gas values in the Marcellus and also highlights the areas in the Mahantango with possible gas potential (Figure 21, Track 4).

$(E q 1-7) S_{w u}=\left(\left(R_{w}^{*} a^{*} T h\right) /\left(\Phi^{m_{*}} \mathrm{U} * R t\right)\right)^{1 / n}$

$\mathrm{S}_{\mathrm{wu}}$ - water saturation for the modified Archie equation (Eq 1-7)

$\mathrm{R}_{\mathrm{w}}$-resistivity of water

a - constant, often 1

$\Phi-$ porosity log

$\mathrm{m}$ - cementation exponent, usually 2-2.2 in the Marcellus

$\mathrm{Rt}$ - true resistivity or deep resistivity

$\mathrm{n}$ - saturation exponent, 2 in this study

Th - thorium log

$\mathrm{U}$ - uranium log

Another commonly used method to correct for the shale content in Archie's equation is the Simandoux shale correction. The Simandoux correction was originally derived for silty sandstone units or inter-bedded sand and shale units to compensate for bound water by using a volume of shale estimate ( $\mathrm{V}_{\mathrm{sh}}$, Eq 1-8). We applied the Simandoux equation (Eq 1-9) to the Marcellus and found since Vsh is almost 100 percent that it over estimates gas content uniformly in the Marcellus and Mahantango shale units (Figure 21, Track 5). 
$(\mathrm{Eq1}-8) \mathrm{V}_{\mathrm{sh}}=\left(\mathrm{GR}_{\mathrm{Log}}-\mathrm{GR}_{\text {Sand }}\right) /\left(\mathrm{GR}_{\text {Shale }}-\mathrm{GR}_{\text {Sand }}\right)$

$$
\mathrm{A}=\mathrm{V}_{\mathrm{sh}} / \mathrm{Rt}_{\mathrm{sh}} \quad \mathrm{B}=\Phi^{\mathrm{m}} /\left(\mathrm{a}^{*} \mathrm{R}_{\mathrm{w}}\left(1-\mathrm{V}_{\mathrm{sh}}\right)\right)
$$

$\left(\right.$ Eq1-9) $S_{w}=\sqrt{ }\left(A^{2}+4 * B * 1 / R t-A\right) /(2 * B)$

$\mathrm{S}_{\mathrm{w}}$ - water saturation

$\mathrm{R}_{\mathrm{w}}$-resistivity of water

a - constant, often 1

$\Phi-$ porosity log

$\mathrm{m}$ - cementation exponent, usually 2-2.2 in the Marcellus

$\mathrm{Rt}$ - true resistivity or deep resistivity

$\mathrm{n}$ - saturation exponent, 2 in this study

$\mathrm{V}_{\mathrm{sh}}$ - volume of shale ratio from the gamma ray log

$\mathrm{Rt}_{\mathrm{sh}}$ - constant of measured true resistivity of shale

$\mathrm{GR}_{\log }$ - gamma ray log

$\mathrm{GR}_{\text {Sand }}$ - constant defined from the gamma ray for a sand

$\mathrm{GR}_{\text {Shale }}$ - constant defined from the gamma ray for a shale

Again one can use the $\mathrm{U}$ content from the spectral gamma ray $\log$ to replaced $\mathrm{V}_{\mathrm{sh}}$ with a calculated relative volume of uranium $\left(\mathrm{V}_{\text {uran }}\right)(\mathrm{Eq} 1-10)$. The $\mathrm{V}_{\text {uran }}$ ratio is calculated by subtracting the uranium $\left(\mathrm{U}_{\log }\right)$ value from $\mathrm{U}_{\max }$ divided by $\mathrm{U}_{\max }$ minus $\mathrm{U}_{\min }$. The substitution of $V_{\text {uran }}$ ratio for the $V_{\text {sh }}$ ratio in the Simandoux equation (Eq 1-11) gives more reasonable saturation values for observed produce water and gas in the Marcellus (Figure 21, Track 5). While the modified Archie and Simandoux equations presented work well in the Marcellus interval, caution would be suggested if this method was to be applied to other gas shale units.

$$
\begin{aligned}
& \left(\text { Eq1-10) } V_{\text {uran }}=\left(U_{\text {Log }}-U_{\max }\right) /\left(U_{\max }-U_{\min }\right)\right. \\
& C=V_{\text {uran }} / \mathrm{Rt}_{U \max } \quad \mathrm{D}=\Phi^{\mathrm{m}} /\left(\mathrm{a}^{*} \mathrm{R}_{\mathrm{w}}\left(1-\mathrm{V}_{\mathrm{Uran}}\right)\right)
\end{aligned}
$$

$(E q 1-11) S_{w u}=\sqrt{ }\left(C^{2}+4 * D * 1 / R t-C\right) /(2 * D)$ 
$S_{w u}$ - water saturation for the modified Simandoux equation (Eq 1-10)

$\mathrm{R}_{\mathrm{w}}$-resistivity of water

a - constant, often 1

$\Phi$ - porosity log

$\mathrm{m}$ - cementation exponent, usually 2-2.2 in the Marcellus

$\mathrm{Rt}$ - true resistivity or deep resistivity

$\mathrm{n}$ - saturation exponent, 2 in this study

$\mathrm{V}_{\text {uran }}$ - volume of uranium ratio

$\mathrm{Rt}_{\mathrm{Umax}}$ - constant of measured true resistivity at the maximum uranium value

$\mathrm{U}_{\log }-$ uranium log

$\mathrm{U}_{\text {Sand }}$ - constant defined from the uranium curve for a sand, lowest value

$\mathrm{U}_{\text {Shale }}$ - constant defined from the uranium curve for a shale, highest value 


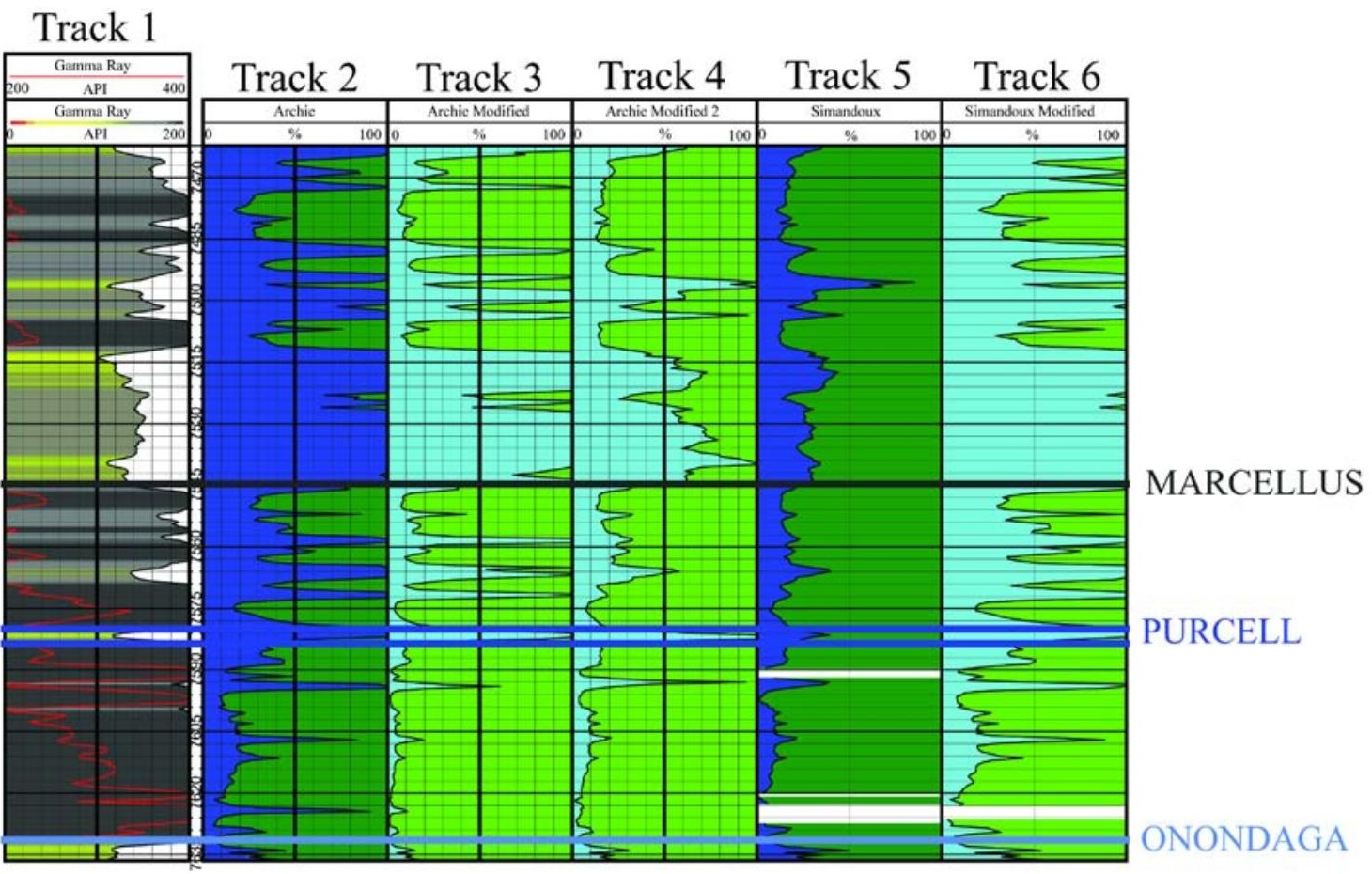

Figure 1-21. Log illustrating multiple approaches to calculating water and gas saturations in the Marcellus Shale. The shades of blue represent water saturation $\left(\mathrm{S}_{\mathrm{w}}\right)$ and the shades of green represent gas saturations $\left(\mathrm{S}_{\mathrm{g}}\right.$ ). The Archie equation (Track 2) significantly overestimates water saturations in the Marcellus. The modification of the Archie equation to include uranium $(\mathrm{U})$ gives a more reasonable representation of the gas-rich and moveable water-poor Marcellus (Boyce and Carr, 2009). Incorporation of both thorium (Th) and $\mathrm{U}$ into the Archie equation (Track 4) improves the representations of the gas and water saturations in the Marcellus as well as the overlying Mahantango. The Simandoux equation (Track 5) significantly overestimates gas saturation for the Marcellus interval. When the Simandoux equation is modified to replace $V_{\text {sh }}$ ratio with $V_{\text {uran }}$ ratio from the $U$ curve (Track 6) the results show a more accurate representation than the original Simandoux equation. 


\subsection{CONCLUSIONS}

The Middle Devonian of the Appalachian basin including the Marcellus Shale interval is an emerging unconventional resource play that can be targeted based upon specific rock characteristics that can be tied to sub-surface well logs. Key parameters that can be identified and analyzed from well logs are the organic richness, lithologic identification, gas identification, and gas/water saturation calculations. Historically many of the gas shale units such as the Marcellus have been investigated to identify source potential and not studied to target specific reservoir properties on a regional basis. Recent methods have been used to identify reservoir potential. However these methods use specialized well logs or other relatively sparse data types (e.g. isotherms, geochemical logs, etc.). In this study, common well logs (e.g. bulk density, photo electric, gamma ray, etc.) are used to identify lithologic changes in the Marcellus interval. In addition to using the common well logs, the spectral gamma ray logs (uranium, thorium, and potassium) were incorporated into calculations for gas identification and gas/water saturations. Based on these analyses, we concluded the following:

1) The Marcellus $X R D$ results showed that the Marcellus is surprisingly rich in quartz and low in illite. Also found was that the Marcellus pyrite and TOC content were high on average, and when plotted against each other, as pyrite increased so did TOC. The two increase in percentage because higher TOC is a result of reducing environments, in which iron is a common by-product, thus increasing the pyrite content in conjunction with the TOC.

2) We found that when the $\mathrm{XRD}$ core data are plotted against the log data in a RHOmaa-Umaa cross plot there is a significant shift in the log data, moving up 
and to the right of the core data. It was concluded that because of the large number of free electrons associated with the iron in pyrite, the Umaa value will shift to the right because of the increased PE value. The movement up on the RHOmaa axis can be tied to the large amount of TOC and free and adsorbed gas present in the Marcellus. Further analysis of the RHOB tool compared to TOC content found that an increase in TOC is associated with a decrease in RHOB. Conversely we found no trend associated with RHOB and pyrite, indicating that the RHOB tool is influenced by the gas associated with the increased TOC, rather than the presence of pyrite.

3) Thorium from the spectral gamma ray log was compared to the XRD results for quartz and illite in the Marcellus. It was observed that as thorium content decreased quartz increased whereas illite decreased. Considering the correlation between thorium content and illite, the thorium curve was compared to the commonly used resistivity curve resulting in a logarithmic relationship. This empirical relationship holds promise for the ability to predict on a regional basis areas of increased clay content for the Marcellus Shale. Identifying areas of low clay content could help in the economic analysis of the Marcellus in relation to the ease in which the unit can be fracture stimulated.

4) The ratio of thorium to potassium illustrated that the Marcellus was illite rich, which correlated well with observation from core analysis. This relationship was regionally correlative. The method can also be applied to identification of thin ash beds in the Marcellus. The ash beds have high values of thorium and can appear in this analysis as an area rich in smectite. 
5) A relationship was identified between logarithmically increasing uranium content and increased TOC content. This relationship was improved on the linear relationship between TOC and RHOB. It was observed that on average the logarithmic relationship between TOC and uranium was more accurate in predicting TOC for the Marcellus. The proposed uranium approach for estimating TOC content using the spectral log is less affected by adverse borehole conditions.

6) The uranium content from the spectral gamma ray was found to be very useful when evaluating organic-richness of the Marcellus Shale. The spectral gamma ray is not a common well log found in the basin, so a relationship between uranium content (ppm) and the standard gamma ray log (API) was evaluated. The polynomial relationship between uranium content and the standard gamma ray appears to be robust at a regional level across the Appalachian basin.

7) Regionally estimated uranium content using the standard gamma ray logs calibrated to available spectral gamma ray logs were used to calculate TOC regionally and a map was produced. This map illustrated a trend (B) with increased organic richness that was previously identified as a slope break environment (Boyce and Carr, in review).

8) A relationship was developed using a density porosity-uranium cross plot. In this cross-plot a line was approximated and it was found that anything above the line may indicative of gas-rich intervals. 
9) The density porosity-uranium concentration curves plotted on an appropriate scale can be used to highlight cross-over between the bulk density and uranium curve to identify probable zones for gas production in the Marcellus.

10) The density porosity-uranium cross plot was used to quantify areas most probable for gas in the Marcellus. This method compared to production could identify areas in the Marcellus that are not only gas rich, but possibly areas with higher volumes of gas.

11) Water saturation equations were revaluated for the Marcellus and other Middle Devonian shale units in the Appalachian basin. Multiple variations incorporating various corrections of the Archie equation were developed and compared. Two methods created appear to more accurately predict water and gas saturations in the Marcellus Shale. The first equation incorporates from the spectral gamma ray log the thorium concentration in the numerator and the uranium concentration into the denominator of the standard Archie equation. The second method was a modified version of the Simandoux shale correction for the standard Archie equation. In this equation, the $V_{\text {shale }}$ ratio is replaced with a $V_{\text {uran }}$ ration that is created from the uranium concentration.

In summary, with sufficient calibration to core data and newer logs such as spectral gamma ray, the Marcellus and related Middle Devonian organic-rich shale units in the Appalachian basin can be effectively evaluated regionally and locally with using common well logs. The spectral gamma ray log is a relatively low-cost and valuable well log for evaluation of organic-rich gas-shale units such as the Marcellus. Incorporation of the spectral log into newly drilled wells can provide 
valuable calibration of more common well logs, assist in identification of gas-rich zones and provide improved insight into accumulation and preservation of organic matter and facilitate regional prospecting for gas-shale. 


\subsection{REFERENCES CITED}

Adams, J.A.S. and Weaver, C. E., 1958, Thorium and uranium ratios as indications of sedimentary process: Example of concept of geochemical facies; American Association of Petroleum Geologists Bulletin, v. 42, p. 387-430.

Anderson, R. J. et. al.,1984, American Association of Petroleum Geologists Correlation Chart; Series 1984.

Archie, G. E. (Schmidt, A., chairperson) , 1986, The electrical resistivity log as an aid in determining some reservoir characteristics; Openhole well logging, SPE Reprint Series, v. 21, p. 310-314.

Beers, R. F., 1945, Radioactivity and organic content of some Paleozoic shales: AAPG Bulletin, vol. 29, p. 1-22.

Boyce, M.L., Carr, T. R., Singh, V., submitted 2010, The Depositional Dynamics of the Middle Devonian Marcellus Interval Using a Petrophysical and Stratigraphic Analysis of the Sub-surface in West Virginia and Southwestern Pennsylvania; submitted to AAPG Bulletin, July 2010,

Boyce, M. L., Carr, T.R., 2009, Lithostratigraphy and petrophysics of the Devonian Marcellus interval in West Virginia and southwestern Pennsylvania: $29^{\text {th }}$ Annual GCSEPM Foundation Bob F. Perkins Research Conference, Houston, Texas; Unconventional Energy Resources; Making the Unconventional Conventional, p. 254281.

Creaney, S., Passey, Q. R., 1993, Recurring patterns of total organic carbon and source rock quality within a sequence stratigraphic framework: AAPG Bulletin, vol. 77, no. 3, p. 386-401.

Demaison, G. J. and G. T. Moore, 1980, Anoxic environments and oil source bed genesis: AAPG Bulletin, v. 64, no. 8, p. 1179-1209.

Doveton, J. H., 1994, Geologic log analysis using computer methods: AAPG Computer Applications in Geology, vol. 2, p. 169.

Dubois, M.K., A.P. Byrnes, T. R. Carr, G.C. Bohling, and J.H. Doveton, 2006, Multiscale geologic and petrophysical modeling of the giant Hugoton gas field (Permian), Kansas and Oklahoma, in P. M. Harris and L. J. Weber, eds., Giant reservoirs of the world: From rocks to reservoir characterization and modeling: American Association of Petroleum Geologists Memoir 88, p. 307-353.

Ettensohn, F. R., 1998, Compressional tectonic controls on epicontinental black-shale deposition; Devonian-Mississippian examples from North America, in Schieber, J., W. 
Zimmerle, and P. S. Sethi, eds.: Shales and mudstones; I, Basin studies, sedimentology, and paleontology, Federal Republic of Germany (DEU), E. Schweizerbart'sche Verlagsbuchhandlung Naegele u. Obermiller, Stuttgart, Federal Republic of Germany (DEU).

Fertl, W. H., and H. H. Rieke, 1980, Gamma-ray spectral evaluation techniques identify fractured shale reservoirs and source-rock characteristics: Journal of Petroleum Technology, v. 31, p. 2053-2062.

Gold, R, 2008, Gas producers rush to Pennsylvania: promising results there spur investment: The Wall Street Journal. page A2.

Hasson, K. O. and J. M. Dennison, 1988, Devonian shale lithostratigraphy, central Appalachians, U.S.A: Devonian of the world; proceedings of the Second international symposium on the Devonian System; Volume II, Sedimentation, Memoir - Canadian Society of Petroleum Geologists, vol. 14, p. 157-177.

Jenkins, C. D. and C. M. Boyer, 2008, Coalbed- and shale-gas reservoirs; Journal Petroleum technology, February, p. 92-99, http://www.spe.org/spesite/spe/spe/jpt/2008/02/17DAS.pdf, accessed 7/19/2010.

Passey, Q, Creaney, S., Kulla, J., Moretti, F., Stroud, J., 1990, A practical model for organic richness from porosity and resistivity logs: AAPG Bulletin, vol. 74, no. 12, p. 1777-1794.

Passey, Q.R., K.E. Dahlberg, K.B. Sullivan, H. Yin, R.A. Brackett, Y.H. Xiao, and A.G. Guzmán-Garcia, 2006, Petrophysical Evaluation of Hydrocarbon Pore-Thickness in Thinly Bedded Clastic Reservoirs, AAPG Archie Series, No. 1, American Association of Petroleum Geologists, Tulsa, Oklahoma, USA, 210p.

Qi, Lianshuang, T. R. Carr, and Robert H. Goldstein, 2007, Geostatistical threedimensional modeling of oolite shoals, St. Louis Limestone, southwest Kansas: American Association of Petroleum Geologists Bulletin, v91, p. 69 - 96.

Repetski, J.E., Ryder, R.T., Weary, D.J., Harris, A.G., and Trippi, M.H., 2008, Thermal maturity patterns (CAI and $\% \mathrm{R}_{0}$ ) in Upper Ordovician and Devonian rocks of the Appalachian basin: A major revision of USGS Map I-917-E using new subsurface collections: U.S. Geological Survey Scientific Investigations Map 3006, one CD-ROM., http://pubs.usgs.gov/sim/3006/, Accessed 7/19/2010.

Schmoker, J. W., 1981, Determination of organic-matter content of Appalachian Devonian shales from gamma-ray logs: AAPG Bulletin, vol. 65, p. 1285-1298. Swanson, V. E., 1960, Oil yield and uranium content of black shales: USGS Professional Paper 356-A, p. 1-44. 
Swezey, C. S., 2002, Regional stratigraphy and petroleum systems of the Appalachian basin, North America: Geologic Investigations Series - U.S.Geological Survey, v. I-2768.

Ward, J., 2008, Log analysis of legacy Marcellus borehole logs, AAPG Eastern Section Meeting, Pittsburgh, Pennsylvania. 
2.0 Lithostratigraphy and Petrophysics of the Devonian Marcellus Interval in West Virginia and Southwestern Pennsylvania

Matthew L. Boyce and Timothy R. Carr

\subsection{ABSTRACT}

In the Appalachian basin, the Middle Devonian organic-rich shale interval, including the Marcellus Shale, is an important target for exploration. This unconventional gas reservoir is widespread across the basin and has the potential to produce large volumes of gas (estimated to have up to 1,307 trillion cubic feet of recoverable gas). Although the Middle Devonian organic-rich shale interval has significant economic potential, stratigraphic distribution, depositional patterns and petrophysical characteristics have not been adequately characterized in the subsurface. Based on log characteristics, tied to core information, the lithostratigraphic boundaries of the Marcellus and associated units were established and correlated throughout West Virginia and southwestern Pennsylvania. Digital well logs (LAS files) were used to generate estimates of lithology and to identify zones of higher gas content across the study area. In addition, a lithologic solution was calibrated to X-ray Diffraction (XRD) data. Using previous studies on organic shale, relationships between the natural radioactivity (as measured by the gamma-ray $\log$ ) were incorporated with techniques to identify gas-prone intervals. The comparison between the Uranium content and the measured bulk density identified intervals in the Marcellus with high gas saturations and were used to generate an approach to correct water saturations. These techniques of identifying lithology and

potential gas in the Marcellus are useful to identify areas of higher exploration potential and to target zones for fracture stimulation or to land a horizontal leg. 


\subsection{INTRODUCTION}

The widely distributed Devonian System of the central Appalachian basin is an important stratigraphic interval from both economic perspective and depositional history. Historically, the majority of petroleum production in the central Appalachians has come from the Upper Devonian. The Middle Devonian, specifically the organic-rich black shale intervals, including the Marcellus Shale, has a long history of marginal gas production (King, 2008), and was considered to be the primary source rock for Upper Devonian and younger conventional reservoirs in the basin. However, new knowledge and technology (e.g., fracture stimulation techniques, horizontal wellbores) indicate that the Middle Devonian units can comprise an extremely productive and widespread unconventional reservoir. Recent estimates of recoverable gas from unconventional shale gas reservoirs in the Appalachian basin have been rising rapidly during the last decade, and by some estimates the Marcellus contains up to 1,307 trillion cubic feet of recoverable gas (Gold, 2008). The area of the Middle Devonian that we will examine encompasses of the state of West Virginia and southwest Pennsylvania. It is located in the central Appalachian basin and covers an area of approximately $23,500 \mathrm{mi}^{2}(60,839$ $\mathrm{km}^{2}$ ) (Figure 2-1). The paleogeographic features that surround the study area are the Acadian Mountains to the east, the Cincinnati Arch to the west and the Rheic Ocean to the south (Figure 2-2). In terms of depositional history the middle Devonian interval represents the initiation of the Devonian-Mississippian anoxic event in the central Appalachian basin (Ettensohn, 1998). It has been suggested that the black shale units represent a deepening basin tied to Acadian tectophases.-In these tectophases, the limestone units represent shallowing-upward periods of deposition (Ettensohn, 1998). 
Other ideas dispute bottom water anoxia and focus on localized enhanced organic matter preservation caused by high concentrations of primary organic matter and sediment being fluxed to the sea floor, as aggregate grains (e.g., Macquaker and others, 2009, Bohacs and others, 2009).

Units of the Middle Devonian interval have been studied primarily in New York and northern Pennsylvania (Ettensohn, 1998; Brett and Ver Straeten, 1994; Linsley, 1994). Work on the Middle Devonian interval in the central Appalachian basin has focused on the depositional characteristics in outcrop. Comprehensive studies on the subsurface relationships and petrophysics of the Middle Devonian interval are lacking in southwestern Pennsylvania and West Virginia (Ettensohn, 1998). The Middle Devonian stratigraphic succession in this area consists of the following formations in ascending order; the Onondaga Limestone (Eifelian), Marcellus Shale (Eifelian), Mahantango Shale (Givetian), Tully Limestone (Givetian), and Harrell Shale (Fransnian-

Givetian) (Anderson et. al., 1984, Hasson and Dennison, 1988) (Figure 2-3). In this paper we define the petrophysical criteria to recognize stratigraphic intervals of the Middle Devonian, and the lithostratigraphic relationships in the subsurface are examined to better understand the depositional history and economic potential.

The purpose of this study is to provide a comprehensive stratigraphic and petrophysical analysis of the Middle Devonian interval in West Virginia and southwestern Pennsylvania. The goals of the proposed research are to integrate available core and well-log data to place the Middle Devonian of the central Appalachians into a stratigraphic framework that can be used to better understand the distribution and controls 
on the extent of organic-rich "black" shale and other facies. A second goal is to develop and refine techniques to recognize and document important lithologic and petrophysical parameters that influence the economic potential of various intervals of the Middle Devonian as unconventional reservoirs. 


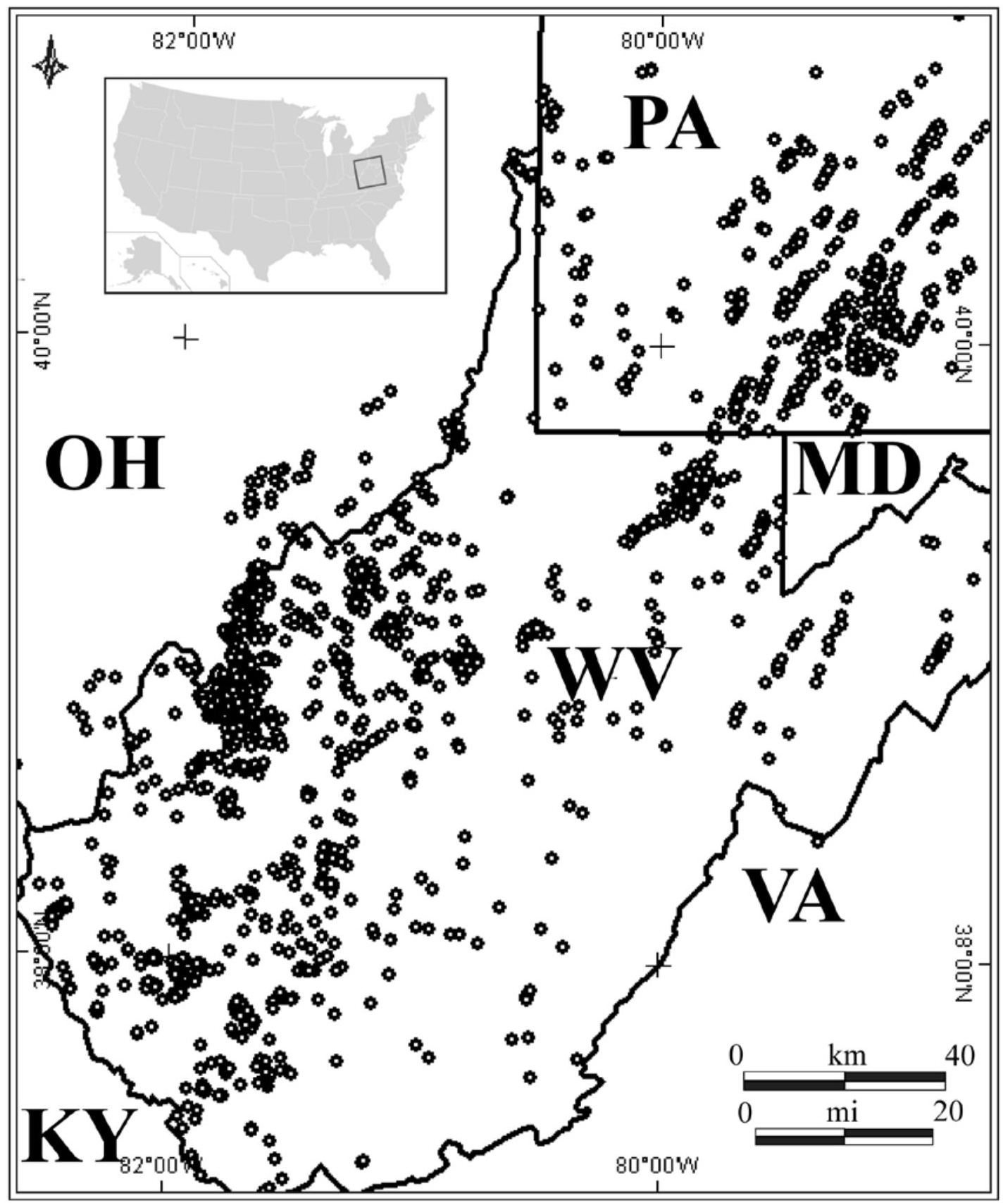

Figure 2-1. The study area encompasses of the state of West Virginia and southwest Pennsylvania. It is located in the geological province of the central Appalachian basin and covers an area of approximately $23,500 \mathrm{mi}^{2}\left(60,839 \mathrm{~km}^{2}\right)$. A total of 1607 wells were correlated (black circles) for this study. 


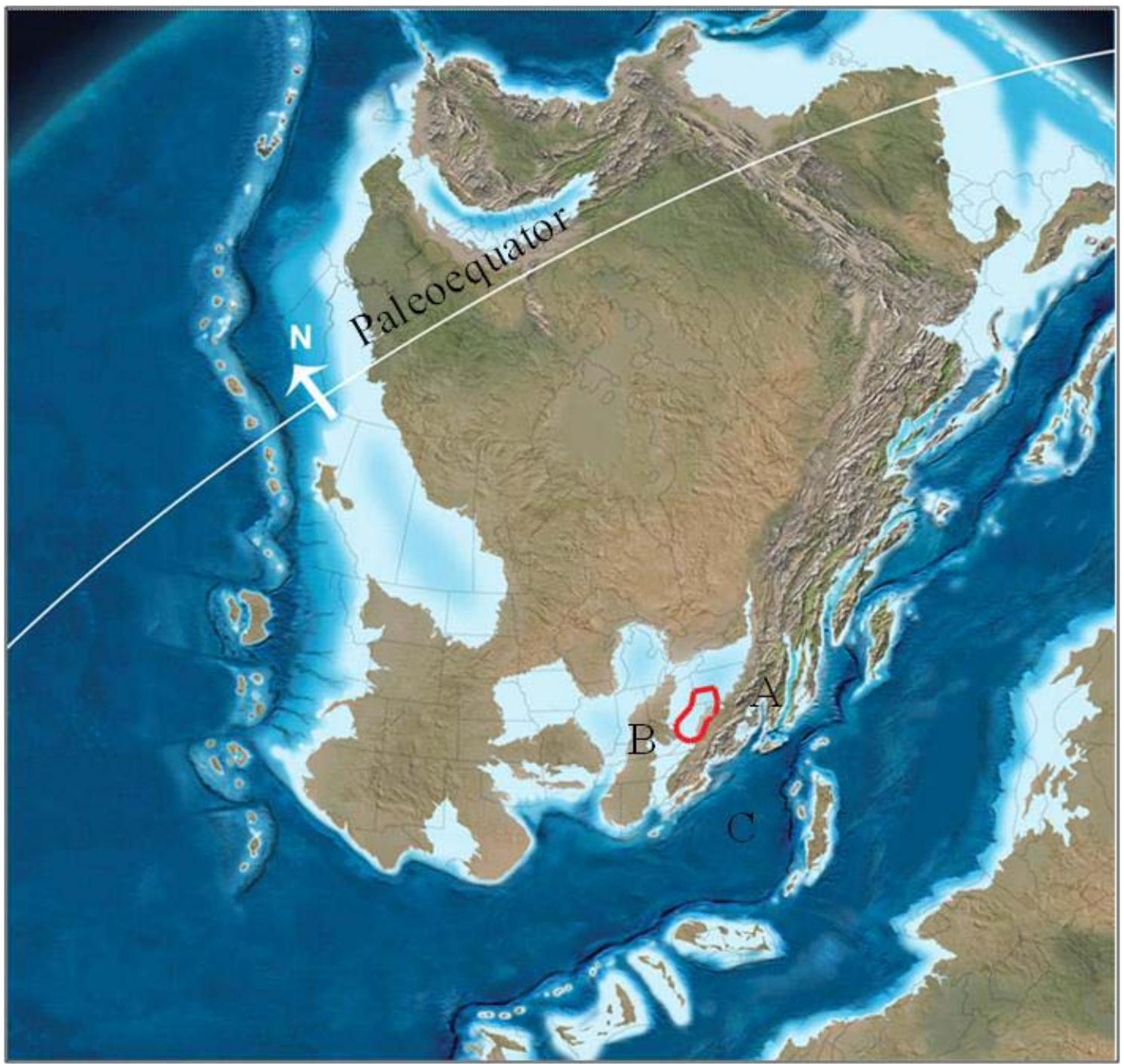

Figure 2-2.-The study area is outlined in red on the paleogeographic interpretation of the Middle Devonian (385 Ma). The paleogeographic features that surround the study area are the Acadian Mountains (A) to the east, the Cincinnati Arch (B) to the west and the Rheic Ocean (C) to the south. This time is significant because it represents the beginning of the Devonian-Mississippian Anoxic Event in the central Appalachian basin. Modified from Blakey (http://jan.ucc.nau.edu/ rcb7/RCB.html) 


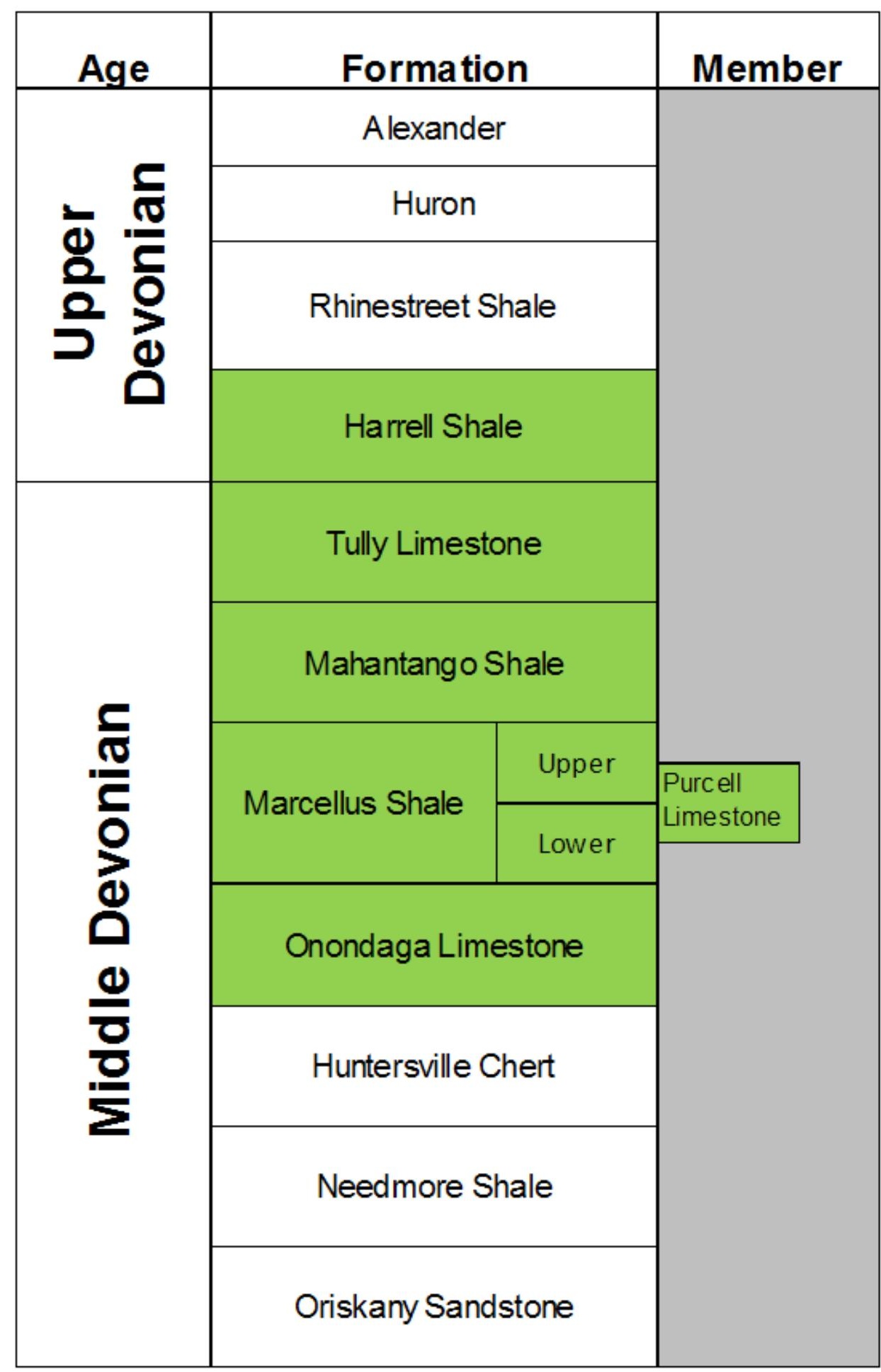

Figure 2-3. Stratigraphic column for the study area. Units that are the subject of this study are highlighted in green. Compiled from Anderson and others (1984) 


\subsection{MIDDLE DEVONIAN LITHOSTRATIGRAPHIC UNITS}

The Onondaga Limestone (Figure 2-3) is a fine-grained limestone that is distributed widely in the subsurface across the study area. On well logs, can be readily identified, by its $\mathrm{PE}$ value $\geq 5$ in response to calcite and has a very sharp contact with the overlying Marcellus (Figure 2-4). In the cores that have been examined, the Onondaga Limestone has a sharp to gradational contact for approximately one foot with the overlying Marcellus Shale. Encased in the Onondaga and basal Marcellus are multiple thin discontinuous ash beds, termed the Tioga Metabentonite (Anderson and others, 1984). While these units are useful, they were not present in the cores acquired for this study and the identification of these thin ash beds is below the resolution of the well log tools.

The Marcellus Shale is typically found deposited on the limestone of the Onondaga Formation, but regional studies indicate that the contact is unconformable, and the Marcellus can be underlain by the Lower Devonian, Huntersville Chert or older strata (Anderson and others, 1985) (Figure 2-3). In several cases, the Onondaga Limestone has been misidentified with a number of discontinuous limestone members within and overlying the Marcellus interval (Anderson and others, 1984).

The Marcellus Shale in core and outcrop is predominantly gray-black to black thinly laminated non-calcareous fissile pyritic organic-rich shale (Figure 2-3). Total organic carbon (TOC) values have been reported of between 0.3 and 11 percent (Nyahay and others, 2007). In the subsurface, we define the Marcellus as having a gamma ray value greater than 200 API and a bulk density less than 2.55 g/cc (Figure 2-4). The 
Marcellus contains one or more thin-bedded limestone beds, including the Purcell Limestone (Figure 2-4). The Purcell is a fine-grained limestone that outcrops to the east of the study area (Dennison and others, 1996). In the subsurface, the Purcell and other thin-bedded limestone beds can be readily recognized by the PE tool. The distribution of the Purcell has been interpreted as irregular across in this study and thickness can range from 0 to 50 feet $(15.2 \mathrm{~m})$. 


\section{Well 4704105144 \\ Lewis County, WV}

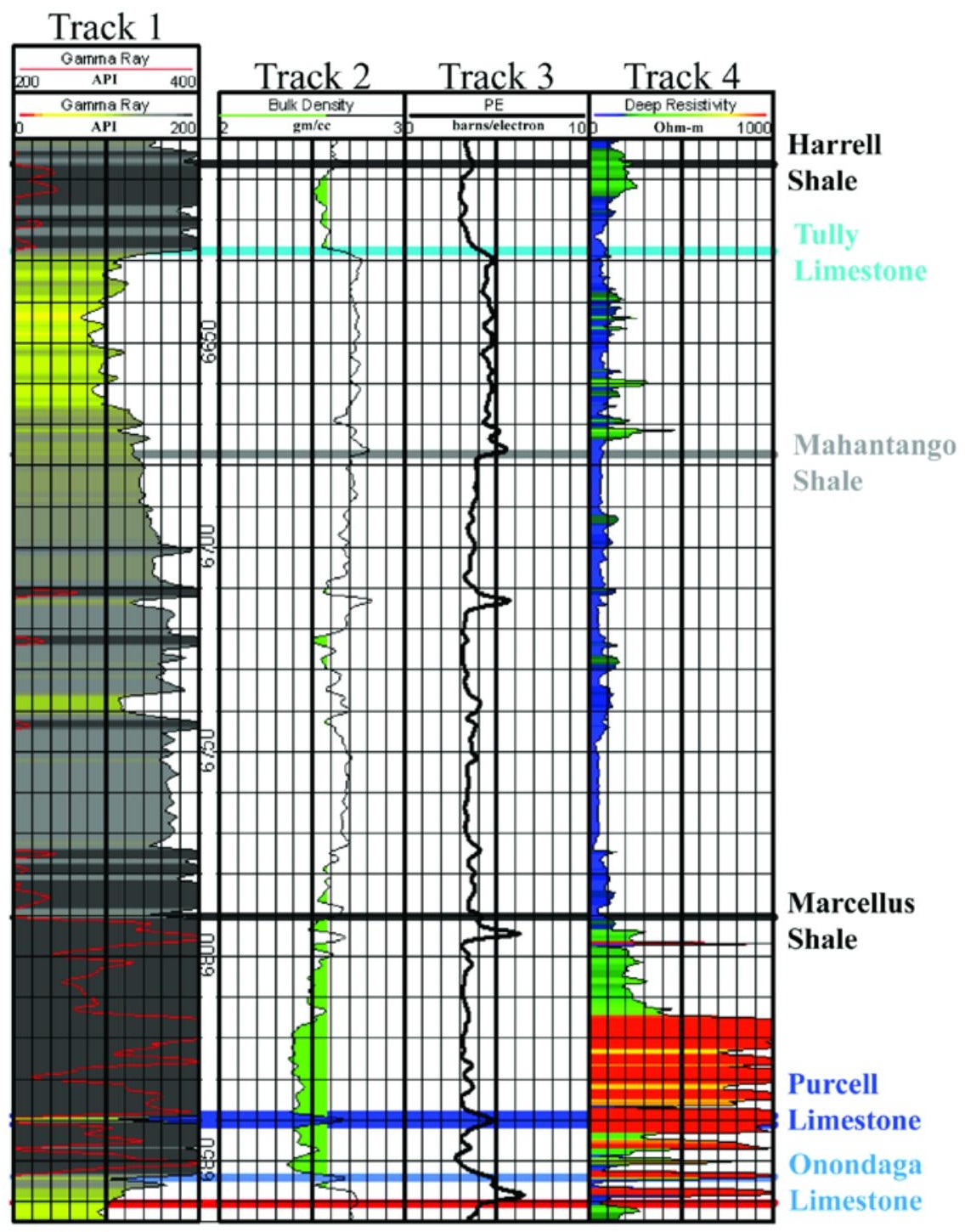

Figure 2-4. Type log for the interval in the study area of West Virginia and southwest Pennsylvania. The gamma ray curve is plotted on track 1 and ranges from 0 to 200 API. When the gamma ray exceeds 200 API it wraps around and is outlined in red. The bulk density curve is plotted in track two and is shaded green for bulk density values less than $2.55 \mathrm{~g} / \mathrm{cc}$. The PE curve is plotted on track 3 and ranges from 0 to 10 barns/electron. The Resistivity curve is plotted in track four and is color coded. The colder colors represent lower resistivity measurements where as the warmer colors represent up to $500 \mathrm{Ohm}-\mathrm{m}$ 's. 
The Mahantango Shale consists of laminated marine shale, siltstone, very fine sandstone, and some limestone, with an occasional coral reef or biostrome and outcrops in eastern West Virginia and central Pennsylvania (Figure 2-4). In eastern West Virginia it is calcareous gray shale with occasional thin limestone beds. In central Pennsylvania, the Mahantango increases in thickness and depositional complexity and contains multiple limestone, sand, and shale units, including the Clearville and Chaneysville siltstone members. In the study area, the Mahantango log signature has gradational contacts with the underlying Marcellus Shale and the overlying Tully Limestone. The Mahantango is defined in the subsurface as having a gamma ray value of less than 200 API and a bulk density value greater than $2.55 \mathrm{~g} / \mathrm{cc}$ (Figure 2-4).

In the study area, the Tully Limestone (Figure 2-4) is a fine-grained limestone and has been intensely studied in outcrop near its type section in New York where it increases significantly in depositional complexity (Heckel, 1966)(Cubitt and others, 1978) (Woodrow and others, 1988). In the subsurface it can be defined by a cleaner (30-110 API) gamma ray signature and an approximate PE value of 5 barns/cc (Figure 2-4).

The Harrell Shale (Figure 2-4) is a dark-gray to black organic-rich fissile shale that is similar to the Marcellus in lithology and possibly its depositional environment. There are calcareous shale and limestone lenses at base near the contact with the Tully Limestone. It is defined by a gamma ray value of greater than 200 API and a bulk density value of less than $2.55 \mathrm{~g} / \mathrm{cc}$ (Figure 2-4). 


\begin{tabular}{|c|c|c|c|}
\hline \multicolumn{4}{|c|}{ Defining Characteristics } \\
\hline Stratigraphic Unit & GammaRay & Pe Value & Bulk Density \\
\hline Onondaga Limestone & Clean (30-110 API) & Aprox. 5 & 2.71 \\
\hline Marcellus Shale & $>200 \mathrm{API}$ & N/A & $<2.55$ \\
\hline Purcell Limestone & $<200 \mathrm{API}$ & Aprox. 5 & 2.71 \\
\hline Mahantango & $<200 \mathrm{API}$ & N/A & $>2.55$ \\
\hline Tully Limestone & Clean (30-110 API) & Aprox. 5 & 2.71 \\
\hline Harrell Shale & $>200 \mathrm{API}$ & $\mathrm{N} / \mathrm{A}$ & $<2.55$ \\
\hline
\end{tabular}

Table 2-2. Summary of the defining characteristics of the stratigraphic units in the study area as displayed in Figure 1-4.

\subsection{DEPOSITIONAL ENVIRONMENTS}

The units in question for this study are thought to have been deposited in a stratified water column with oxic, sub-oxic, and anoxic zones. The oxic zone would correlate to the Tully, Purcell, and Onondaga limestone units. The Mahantango is interpreted as having been deposited in the sub-oxic zone. The Marcellus and Harrell shale units are interpreted to have been deposited in the anoxic zone. In order for a stratified water column to develop, the environment must have three things: a large influx of organic matter, low circulation, and low sediment input (Demaison and Moore, 1980, Ettensohn and Barron, 1982). The excess of organic material that is input into the system would first be oxidized by the aerobic bacteria in the oxic zone, using the oxygen in the water column to degrade the organic matter. However, if there is a large amount of organic matter in the system, excess organic matter would not be degraded by the aerobic bacteria and be incorporated into the sub-oxic zone. In the sub-oxic zone, the insufficient oxygen supply requires anaerobic bacteria to use nitrates as an oxidant. In addition to the increase consumption by the bacteria, anaerobic bacteria degrade organic matter much more slowly than aerobic bacteria. This process can allow for organic matter to move 
through the sub-oxic zone, into the anoxic zone (Demaison and Moore, 1980). In the anoxic zone, all the oxygen, as well as the available nitrates, has been consumed requiring the anaerobic bacteria to use any available sulfates as an oxidant to degrade the organic matter (Demaison and Moore, 1980). The byproduct of the degradation of organic matter with sulfates is hydrogen sulfide, which can accumulate in a pool at the ocean floor in a stratified water column. Once the organic matter moves into the anaerobic zone and reaches the sea floor, it can be incorporated into the sediment resulting in preservation of allowing for a large amount of organic matter. This depositional model is based on the modern depositional environment of the Black Sea, and is consistent with bottom waters that are synchronously anoxic (Demaison and Moore, 1980, Ettensohn and Barron, 1982).

Recently micro-anoxic environments have been proposed, rather than synchronous anoxic bottom waters (e.g., Macquaker and others, 2009, Bohacs and others, 2009). These ideas dispute widespread bottom water anoxia, and focus on enhanced organic matter preservation resulting from localized anoxia resulting from by high concentrations of primary organic matter and sediment being fluxed to the sea floor, as aggregate grains. This would suggest that the entire basin was not synchronously anoxic, and consequently could explain rapid spatial changes in thickness of Middle Devonian organic-rich shale intervals, including the Marcellus Shale, and the presence of limestone members in the Marcellus. 


\subsection{LITHOLOGIC ANALYSIS AND RECOGNITION OF GAS-RICH INTERVALS}

X-ray diffraction (XRD) of 36 organic-rich Marcellus Shale core samples show that the interval is characterized by relatively high quartz contents (60\%) and relatively low clay content (muscovite-illite 30\%) (Figure 2-5). Pyrite, an important component that significantly affects log analysis, can range from 5 to $10 \%$. The effect of pyrite and gas content in the Marcellus can be recognized on the Rhomaa Umaa plot (Figure 2-6). The Rhomaa-Umaa cross plot shows the effects of the small amount of pyrite (pulling the data to the right due to the high number of electrons associated with the iron in pyrite), and the gas pulling the data above the lithologic triangle (low Rhomaa due to the low density of gas). The influence of these two components must be taken into consideration when attempting to model the Marcellus lithology and petrophysical parameters (e.g., porosity).

In the Marcellus, a relationship associated with gas-rich intervals has been recognized between the gamma ray and density porosity (Ward. 2008). We note a similar relationship and associate this relationship specifically to the uranium (U) content as recognized by the spectral gamma-ray log (Figure 2-7). The U-content is one of the major naturally occurring decay series that contribute to the gamma-ray response, and can be measured as parts per million (ppm) by the spectral gamma-ray tool. As measured in core samples of the Middle Devonian shale intervals, the elevated U-content is

associated with increased total organic content (TOC). The decreased density (increased density porosity) as the U-content increases is attributed to increased gas content adsorbed to the organic material and as free-gas in matrix and fracture porosity. The 
relationship between the U-content and density porosity is used to highlight gas-rich intervals within the Middle Devonian shale units of the Appalachian basin (both free-gas and adsorbed). In general, using a cross-plot of U-content and density porosity shows that the Marcellus Shale has significant gas-rich intervals as compared to the Mahantango and Harrell shale units. Uranium-content and density porosity can be plotted together to highlight potential gas-rich intervals (Figure 2-8). Using an appropriate scale, zones where the U-content exceeds the bulk density value are highlighted, and interpreted as having a high potential as gas-rich intervals. In addition, to the identification of gas-rich intervals in the Marcellus, similar gas-rich intervals are indicated in the Mahantango and Harrell shale units (Figure 2-8). The possible gas-rich intervals indicated in both the Mahantango and Harrell could influence exploration in other Middle Devonian shale units of the Appalachian basin. 


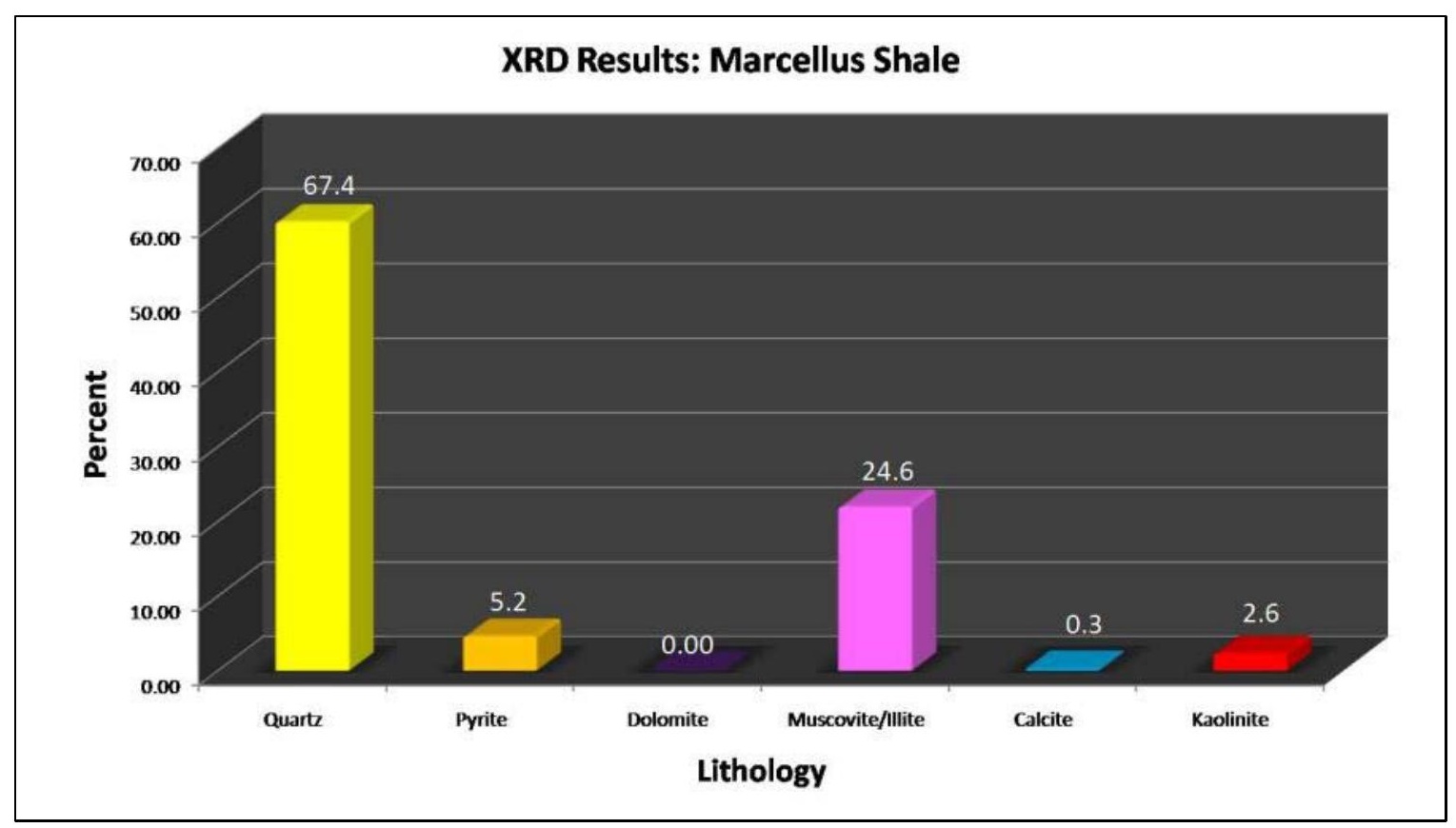

Figure 2-5.- Example of X-Ray Diffraction (XRD) results for a single core sample from the Marcellus in the study area (Figure 1-1). This sample has a high amount of quartz (67.4\%) and fairly low amount of clay (24.6\%), which is characteristic of the 36 Marcellus Shale core samples examined throughout the study area. Also it is important to identify the significant amount of pyrite. This sample has about $5 \%$ but the samples can range from 5-10\% pyrite. 


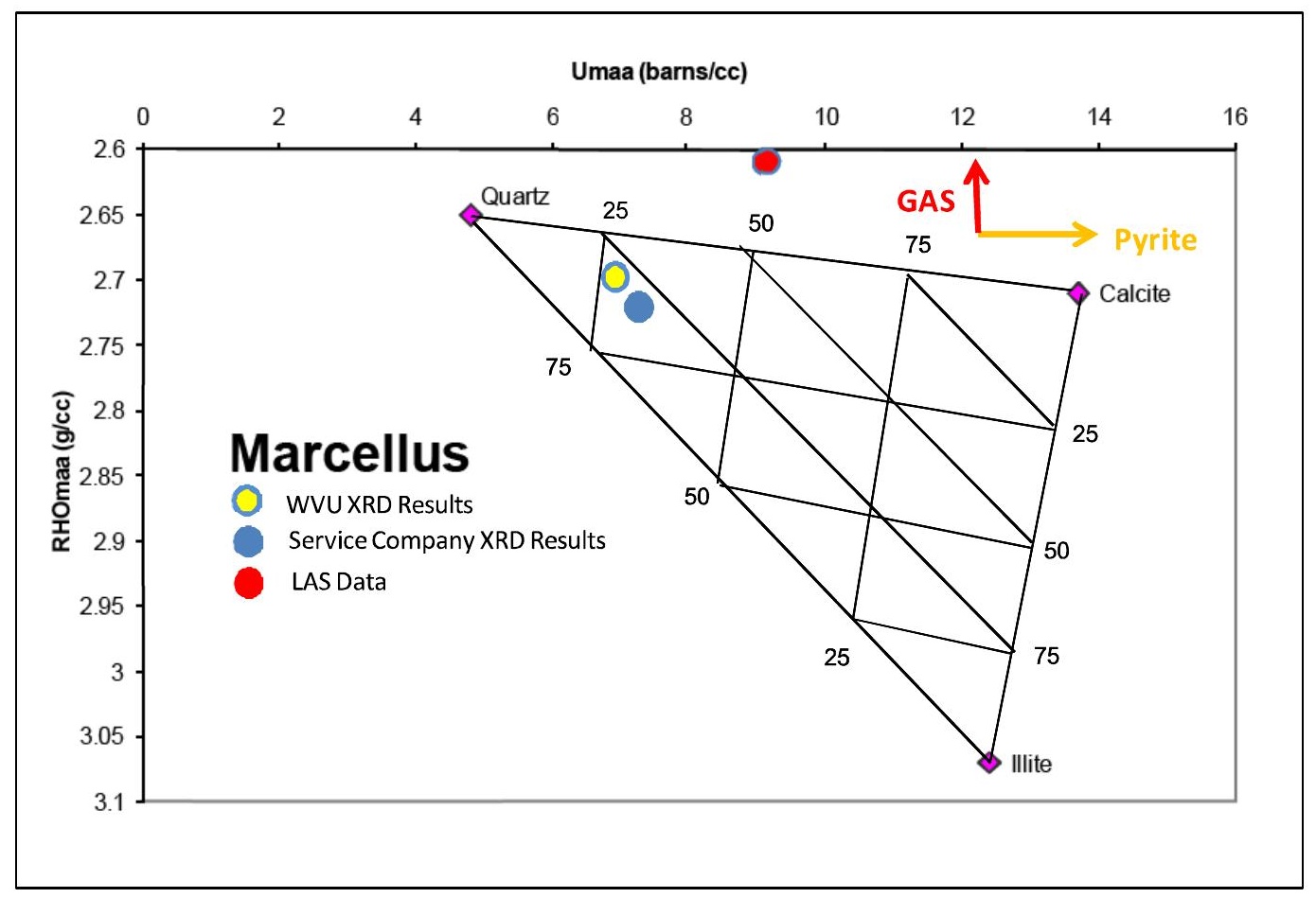

Figure 2-6. Example of a Rhomaa Umaa plot compared with XRD results from a single core sample of the Marcellus Shale. XRD results for the same sample analyzed at both West Virginia University and provided by a service company are shown (WVU yellow and the service company blue). The red circle is the result of the Rhomaa-Umaa cross plot for the same interval represented by the core sample showing that the effects of the small amount of pyrite (pulling the data to the right due to the high number of electrons associated with the iron in pyrite), and the gas pulling the data above the lithologic triangle (low Rhomaa due to the low density of gas). The influence of these two components must be taken into consideration when attempting to model the Marcellus lithology and petrophysical parameters (e.g., porosity). 


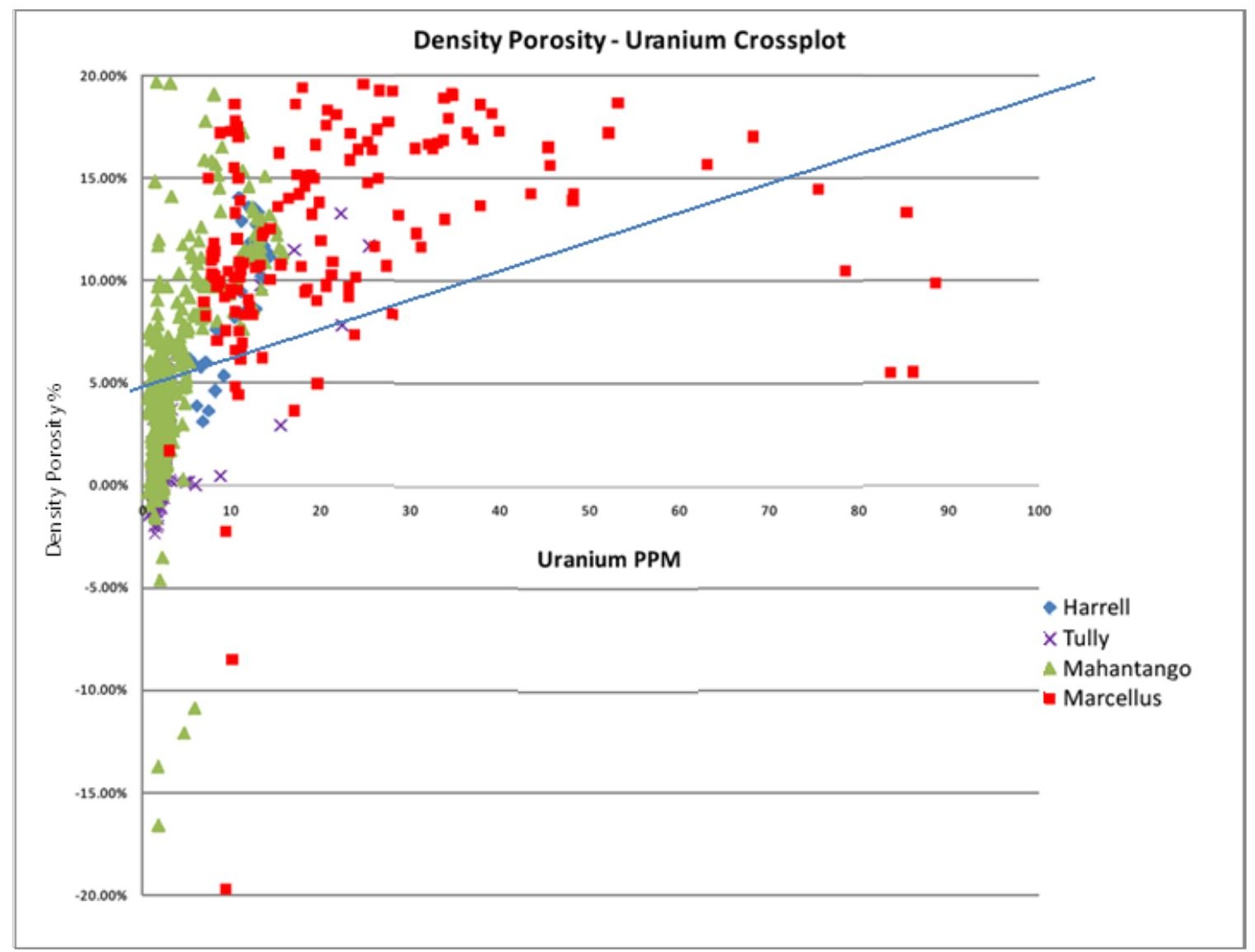

Figure 2-7. Cross plot of uranium in ppm versus density porosity. Anything above the blue line is considered to be free gas or sorbed gas to organic matter. 


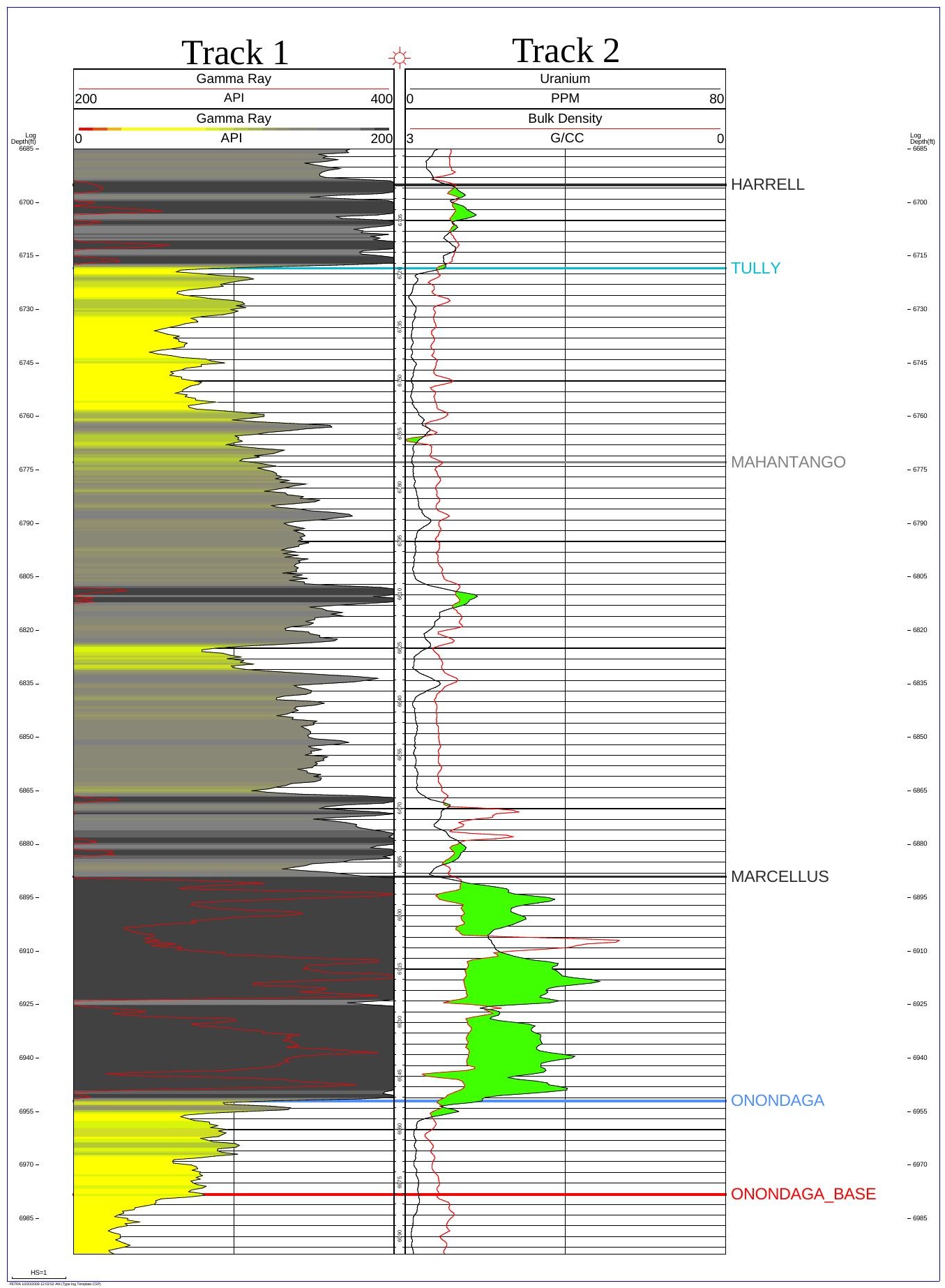

Figure 2-8. Uranium content and density porosity can be plotted together (Track 2) to highlight potential gas-rich intervals. Using an appropriate scale, zones where the Ucontent exceeds the bulk density value are highlighted, and interpreted as having a high potential as gas-rich intervals. In addition, to the identification of gas-rich intervals in the Marcellus Shale, similar gas-rich intervals are indicated in the Mahantango and Harrell shale units. 
The uranium (U) content as indicated by the spectral log can be incorporated into other pay calculations. The water saturation for the Marcellus is typically calculated by using the Archie equation (Equation 2-1) or the Simandoux shale correction for the Archie equation (Equation 2-3). The Archie is a more conservative equation that was originally derived to be used in a clean (shale-free) lithology (e.g., sandstone). The equation does not take into account shale particles that suppress resistivity or the measured tortuosity of shale. The Archie equation significantly overestimates water saturations in the largely water-free Middle Devonian shale units of the Appalachian basin (Figure 2-9). We have directly incorporated the Uranium into a modified Archie equation (Equation 2-2, Figure 2-9). We believe this modified Archie equation provides a better estimate of gas and water saturation in the Marcellus. Another approach to correcting for shale content is the Simandoux shale correction for the Archie equation. The Simandoux equation was derived specifically for sandy-shaly units to compensate for bound water by using an estimate for the volume of shale $\left(\mathrm{V}_{\mathrm{sh}}\right)$ determine from the gamma ray tool. When the Simandoux correction is applied to Middle Devonian shale units of the Appalachian basin, it overestimates intervals of high gas content (Figure 2-9). uranium content was used to derive a ratio similar to $\mathrm{V}_{\mathrm{sh}}$. The relative volume of uranium $V_{\text {uran }}$ was substituted for a $V_{\text {sh }}$ ratio in the Simandoux shale correction for the Archie equation (Equation 2-4). The $\mathrm{V}_{\text {uran }}$ ratio is calculated by subtracting the Uranium $\left(\mathrm{U}_{\log }\right)$ value from $\mathrm{U}_{\max }$ divided by $\mathrm{U}_{\max }$ minus $\mathrm{U}_{\min }$. We believe the substitution of the $\mathrm{V}_{\text {uran }}$ ratio can provide an improved estimate of gas and water saturation in the organicrich shale units. 


$$
S_{W}=\left(\frac{R_{w} * a}{\Phi^{m} * R t}\right)^{\frac{1}{n}}
$$

Equation 2-1. Standard Archie water saturation equation.

$$
S_{w u}=\left(\frac{R_{w} * a}{\Phi^{m} * R t * U_{l o g}}\right)^{\frac{1}{n}}
$$

Equation 2-2. Modified Archie equation with the uranium log $\left(\mathrm{U}_{\mathrm{log}}\right)$.

$$
S_{W}=\frac{\sqrt{\left(\frac{V_{s h}}{R_{s h}}\right)^{2}+4 *\left(\frac{\Phi^{m}}{a * R_{w}\left(1-V_{s h}\right)}\right) * \frac{1}{R t}}-\frac{V_{s h}}{R_{s h}}}{2 *\left(\frac{\Phi^{m}}{a * R_{w}\left(1-V_{s h}\right)}\right)} \Rightarrow V_{s h}=\frac{G R \text { - Sand }}{\text { Shale - Sand }}
$$

Equation 2-3. Simandoux shale correction for the standard Archie equation using a $V_{\mathrm{sh}}$ ratio.

$$
S_{W U}=\frac{\sqrt{\left(\frac{V_{u r a n}}{R_{U m a x}}\right)^{2}+4 *\left(\frac{\Phi^{m}}{a * R_{w}\left(1-V_{u r a n}\right.}\right) * \frac{1}{R t}}-\frac{V_{u r a n}}{R_{U m a x}}}{2 *\left(\frac{\Phi^{m}}{a * R_{w}\left(1-V_{u r a n}\right.}\right)} \Rightarrow V_{u r a n}=\frac{U_{\text {lag }}-U_{\max }}{U_{\text {max }}-U_{\text {min }}}
$$

Equation 2-4. Modified Simandoux equation using a $V_{\text {uran }}$ ratio. 


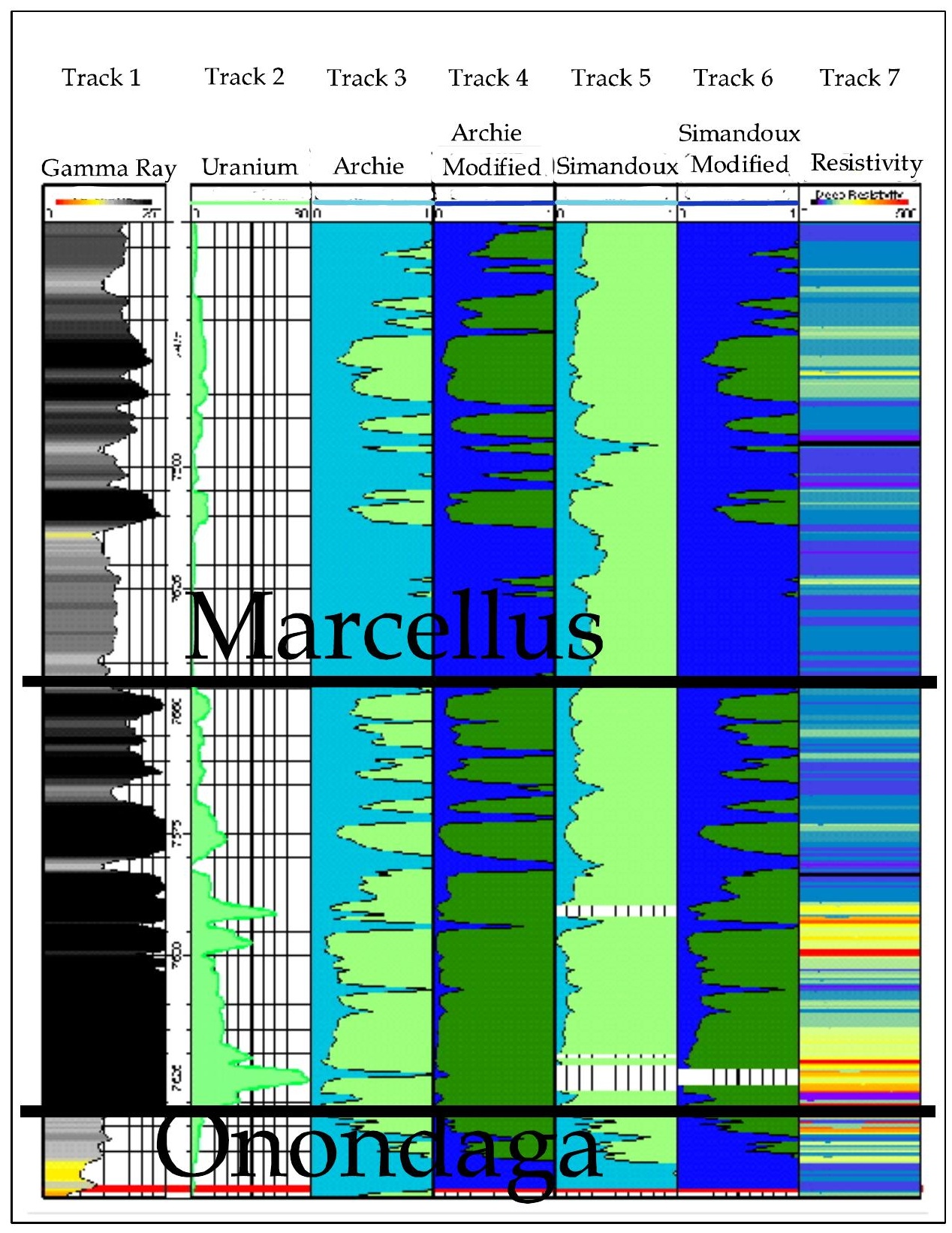

Figure 2-9. Log illustrating multiple approaches to calculating water and gas saturation in the Marcellus Shale. The light blue and dark blue represent $S_{\mathrm{w}}$ and the light green and dark green represent $S_{g}$. The Archie equation significantly overestimates water saturations (Track 3). Incorporating Uranium into a modified Archie equation provides a better estimate of gas and water saturation (Track 4). The Simandoux equation overestimates intervals of high gas content (Track 5). Relative Uranium content ( $\mathrm{V}_{\text {uran }}$ ) was substituted for $V_{\text {sh }}$ to construct a modified Simandoux correction for Archie equation (Track 6). We believe the substitution of the $V_{\text {uran }}$ ratio can provide an improved estimate of gas and water saturation in the organic-rich shale units of the Appalachian basin. 


\subsection{ISOPACH MAPS OF MIDDLE DEVONIAN UNITS}

Using subsurface defined criteria, isopach maps of Middle Devonian units in the study area were constructed using log suites from more than 1452 available wells. In the study area the Marcellus Shale shows a decrease in thickness from over 180 feet (54.9 m) in the northeast to less than 10 feet $(3 \mathrm{~m})$ in southwest West Virginia (Figure 1-10). Much of this decrease in thickness from 100 to 60 feet (30.4 to 18.3m) is concentrated along a northwest to southeast trend from Doddridge to Pocahontas counties in West Virginia (Figure 2-10, labeled B). This northwest to southeast trend persists in the overlying Middle Devonian units. An anomalous thick in the Marcellus Shale (Figure 2-10, label A) trends southwest to northeast from Roane to Tyler counties, West Virginia and is believed to be associated with the west-bounding limb of the Rome Trough structure, and suggests that the structure was active during deposition.

To better understand the distribution of potentially organic-rich intervals in the Marcellus Shale, an isopach map was constructed with gamma-ray values greater than 230 API (Figure 2-11). Based on examination of available spectral gamma-ray logs and core data, gamma-ray values greater than 230 API are indicative of high uranium (U) concentration associated with high TOC and potential gas-rich intervals. The majority of pre-existing log suites do not contain spectral gamma-ray data, so the thickness of elevated gamma-ray curve ( $>230$ API) is used as a proxy for organic-rich intervals in the Marcellus Shale (Figure 2-11). Based on the thickest "hot" gamma-ray zones, the potential gas-rich intervals are associated with intermediate thicknesses of the Marcellus

Shale in a zone from central and north-central West Virginia to southwest Pennsylvania (Figure 2-11). 


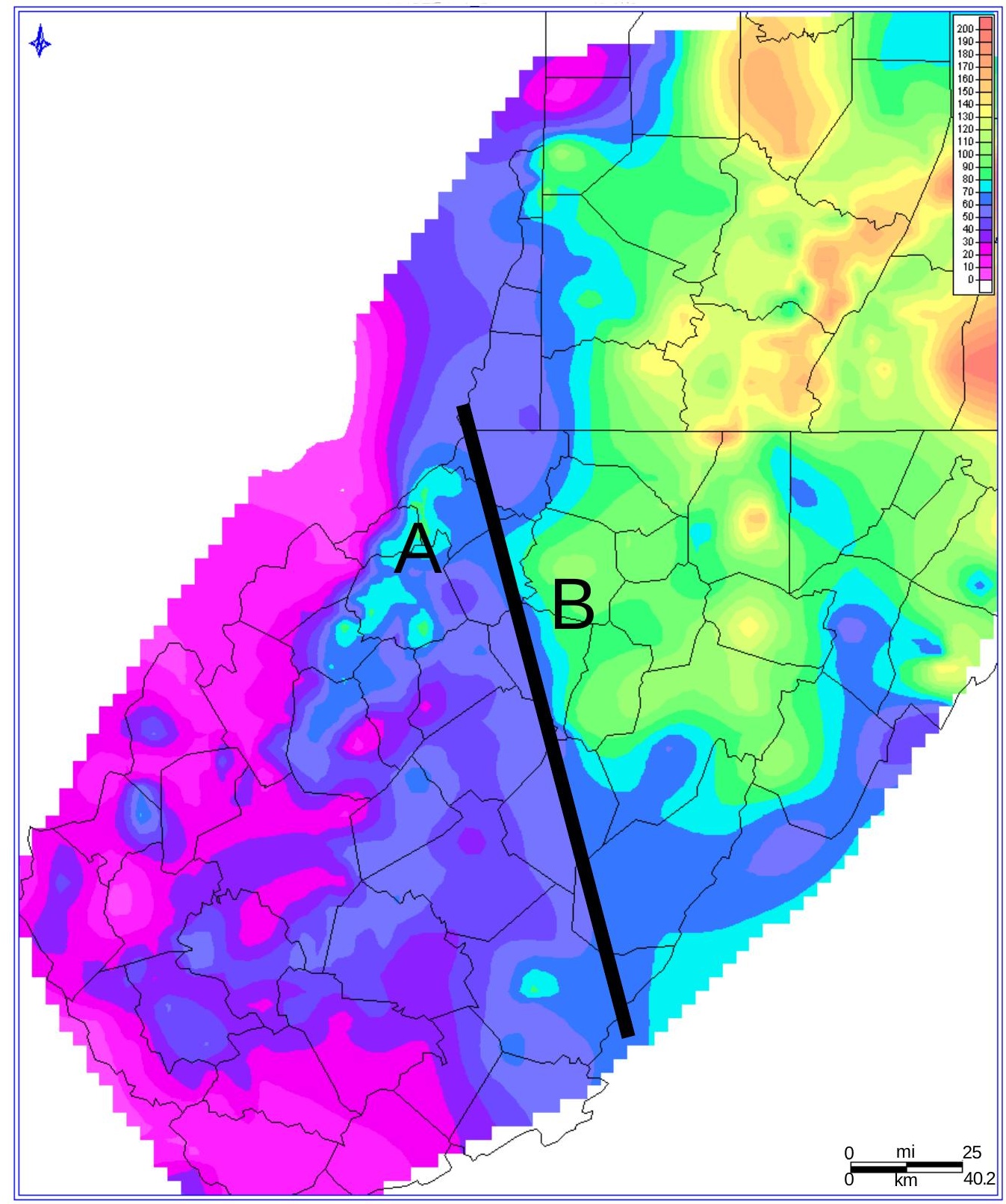

Figure 2-10. Isopach of the Marcellus Shale across the study area showing a decrease in thickness from over 180 feet $(54.9 \mathrm{~m})$ in the northeast to less than 10 feet $(3 \mathrm{~m})$ in southwest West Virginia. Rapid decrease in thickness is concentrated along a northwest to southeast trend from Doddridge to Pocahontas counties in West Virginia (B). This feature persists and influences the deposition of the overlying units (Figure 2-13 \& 2-15) An anomalous thick in the trends southwest to northeast from Roane to Tyler counties, West Virginia (A), and is associated with the west-bounding limb of the Rome Trough structure. Trend A suggests that the Rome trough was active during Marcellus deposition but does not appear to influence the overlying units. 


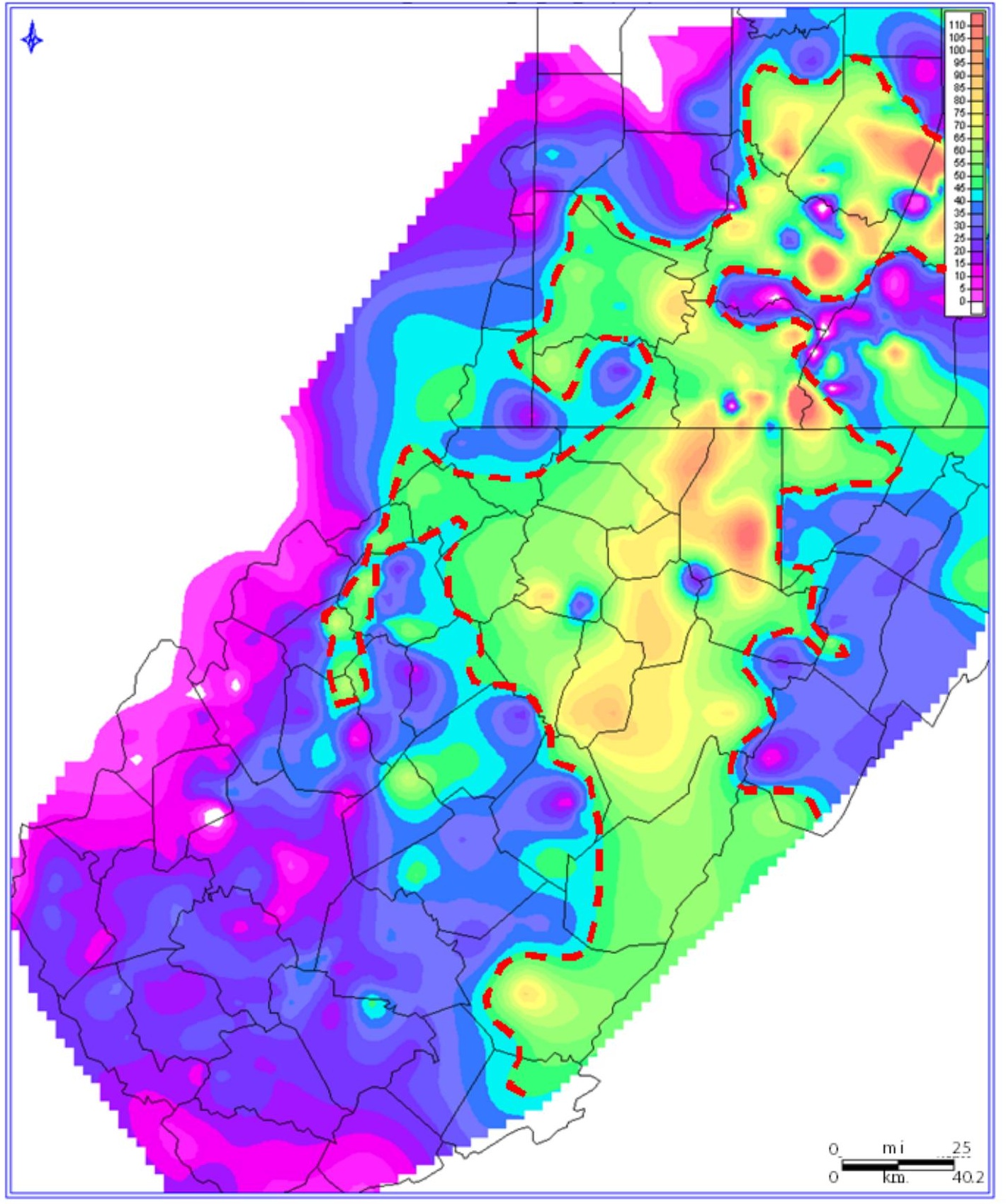

Figure 2-11. Isopach map of intervals of the Marcellus Shale with gamma-ray values greater than 230 API. The thickness of elevated gamma-ray curve ( $>230$ API) is used as a proxy for thick organic-rich intervals in the Marcellus Shale. The thickest potential gas-rich intervals are associated with intermediate thicknesses of the Marcellus Shale in a zone from central and north-central West Virginia to southwest Pennsylvania (red dashed line). 
An isopach map of the Purcell Limestone Member of the Marcellus Shale shows a northeast to southwest thickness trend and the limestone unit generally does not occur in the west or central regions of the study area. (Figure 2-12). This map is representative of limestone units within the Marcellus Shale. The one exception is the west to east trend in the northern region of the study area (C). The Purcell is particularly interesting because it is encompassed by the Marcellus Shale. The Purcell is interpreted as deposited in a relatively oxic environment, while the Marcellus Shale is believed to have been deposited in an anoxic environment. According to the widespread stratified water-column model, sea level would have had to drop sharply for the Purcell to be deposited, while remaining deep in the west and north. The relationships between these units might be better explained by relatively localized anoxic environments influenced by factors such as sediment supply, paleo-topography and water chemistry. The concentration of thicker organic-rich intervals in the Marcellus Shale in the zone from central and north-central West Virginia to southwest Pennsylvania suggests that simple water-column stratification model is inadequate (Figure 2-11).

An isopach of the Mahantango Shale shows that the unit can be as thick as 800 feet $(243.9 \mathrm{~m})$ in the northeast of the study area and is decreasing to the south and to the west (Figure 2-13). The Mahantango outcrops to the northwest in central Pennsylvania and eastern West Virginia. In northwest Pennsylvania, the Mahantango is more depositionally complex than is observed in the subsurface and in the outcrop of eastern West Virginia. In central Pennsylvania, the Mahantango contains a variety of beds including limestone, conglomerates, sands and shale units that have a wide range of sedimentary structures (Duke, Prave and others, 1991). Moving south along the outcrop 
belt of eastern West Virginia and into the subsurface of southwest Pennsylvania and central West Virginia, the Mahantango lacks the variety of lithologies and sedimentary structures, and is primarily calcareous shale with occasional limestone beds. The thick organic-rich Marcellus Shale appears to wrap around the area were the overlying Mahantango is thickest. The northwest to southwest trend observed in the Marcellus Shale appears to affect the southwest extent of the Mahantango Shale (Figure 2-13, Trend D).

Across the study area, the Tully Limestone decreases in thickness to the south and east (Figure 2-14). The Tully is thickest to the north coinciding with the thinning of the underlying Mahantango Shale (Figure 2-13) and is absent where the Mahantango is thickest (Figure 2-14, D). The Mahantango does have a calcareous component in outcrop that could be correlative to the Tully Limestone. The clastic sediment content and rapid deposition of the Mahantango could have prevented development of the Tully Limestone. The southern extent of the Tully Limestone is marked by a northwest to southeast trend (B) in the same geographic area as recognized in the underlying Marcellus and Mahantango (Figures 2-10, 2-11, 2-12, 2-13, 2-14).

The thickest values for the Harrell Shale isopach are located in north-central West Virginia (Figure 2-15). The northwest to southeast trend observed in the underlying units appear to affect Harrell deposition, but not as severely as the underlying units (B). The Harrell Shale appears to be acting as a flooding sequence, because after the deposition of this unit carbonates do not appear in the stratigraphic section until the lower Mississippian. An isopach of the thickness of Harrell Shale with gamma ray values greater than 230 API was constructed (Figure 2-16). The thick potentially gas-rich 
interval runs in an arc through central West Virginia into the northern panhandle and extreme southwest Pennsylvania and is offset from the thick in the underlying Mahantango Shale (Figure 2-13). 


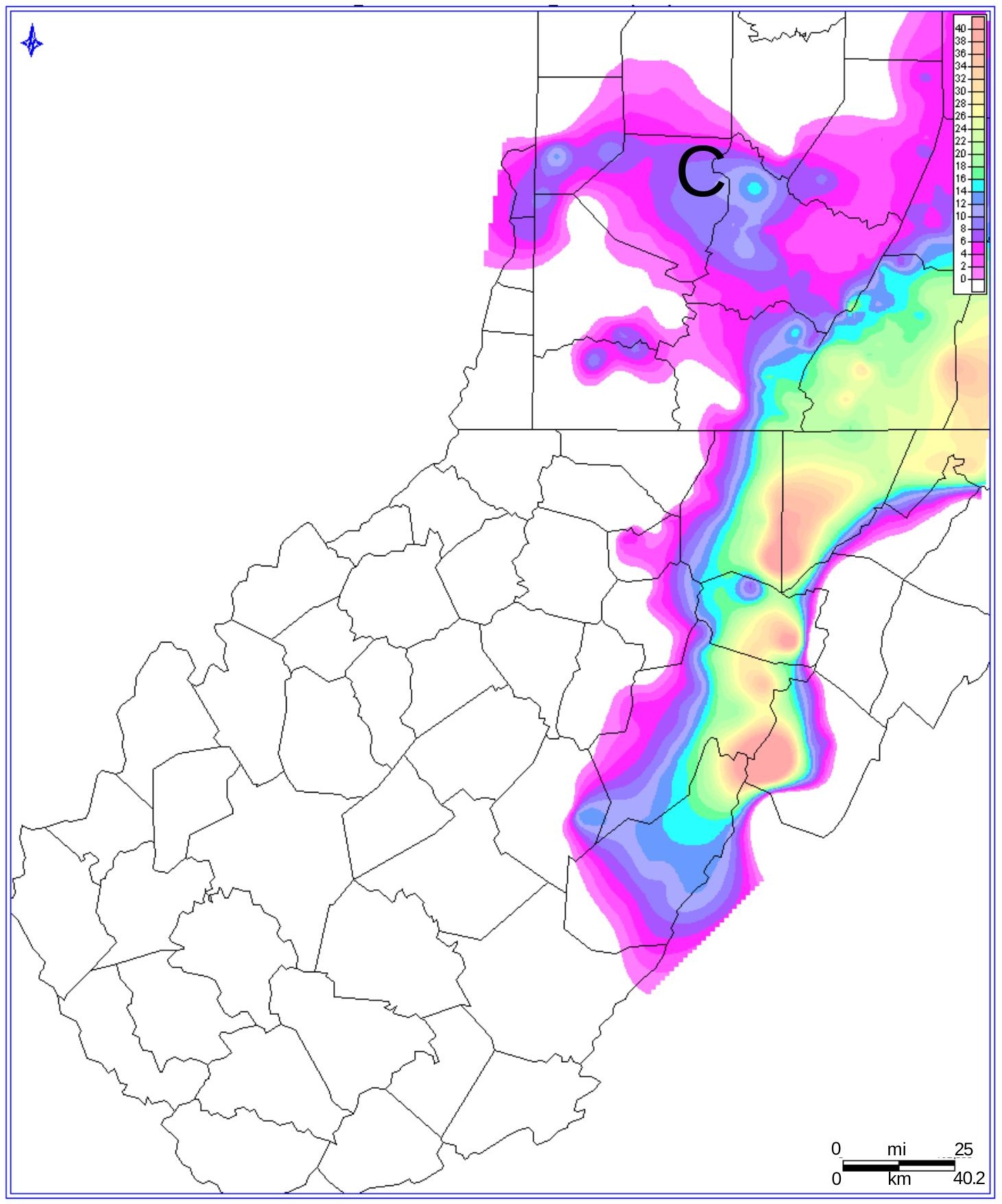

Figure 2-12. Isopach of the Purcell Limestone Member within the Marcellus Shale showing a northeast to southwest trend and the limestone unit generally does not occur in the west or central regions of the study area. The one exception is the thin west to east trend in the northern region of the study area (C). The relationship between the Purcell and the enclosing Marcellus Shale might be better explained by relatively localized anoxic environments influenced by factors such as sediment supply, paleo-topography and water chemistry. 


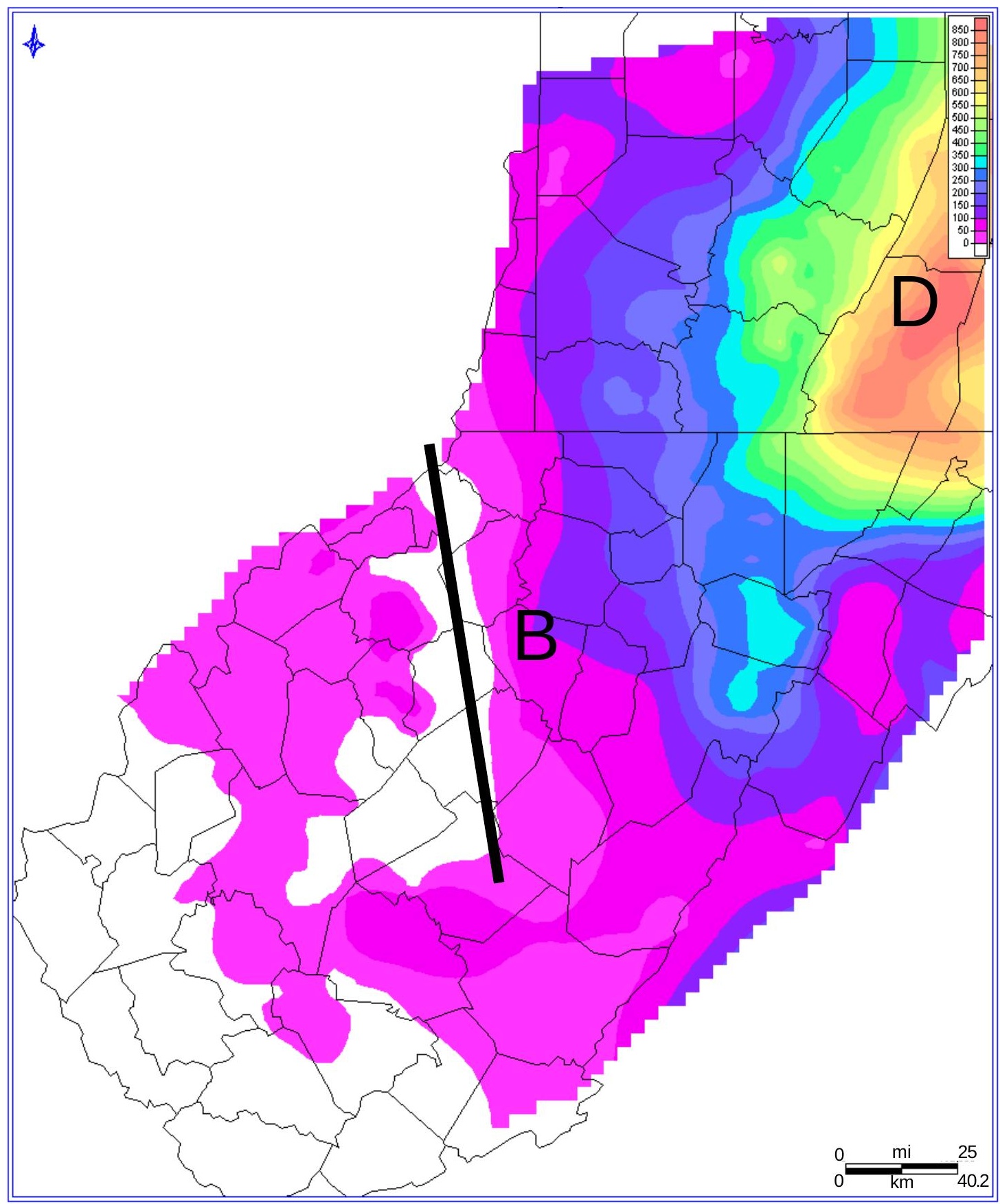

Figure 2-13. Isopach of the Mahantango Shale showing that the unit can be as thick as 800 feet $(243.9 \mathrm{~m})$ in the northeast (D) of the study area and decreases to the south and to the west. The thick organic-rich Marcellus Shale (Figure 2-11) appears to wrap around the area were the overlying Mahantango is thickest. The northwest to southwest trend observed in the Marcellus Shale (Figure 2-11) appears to affect the southwest extent of the Mahantango Shale (B). 


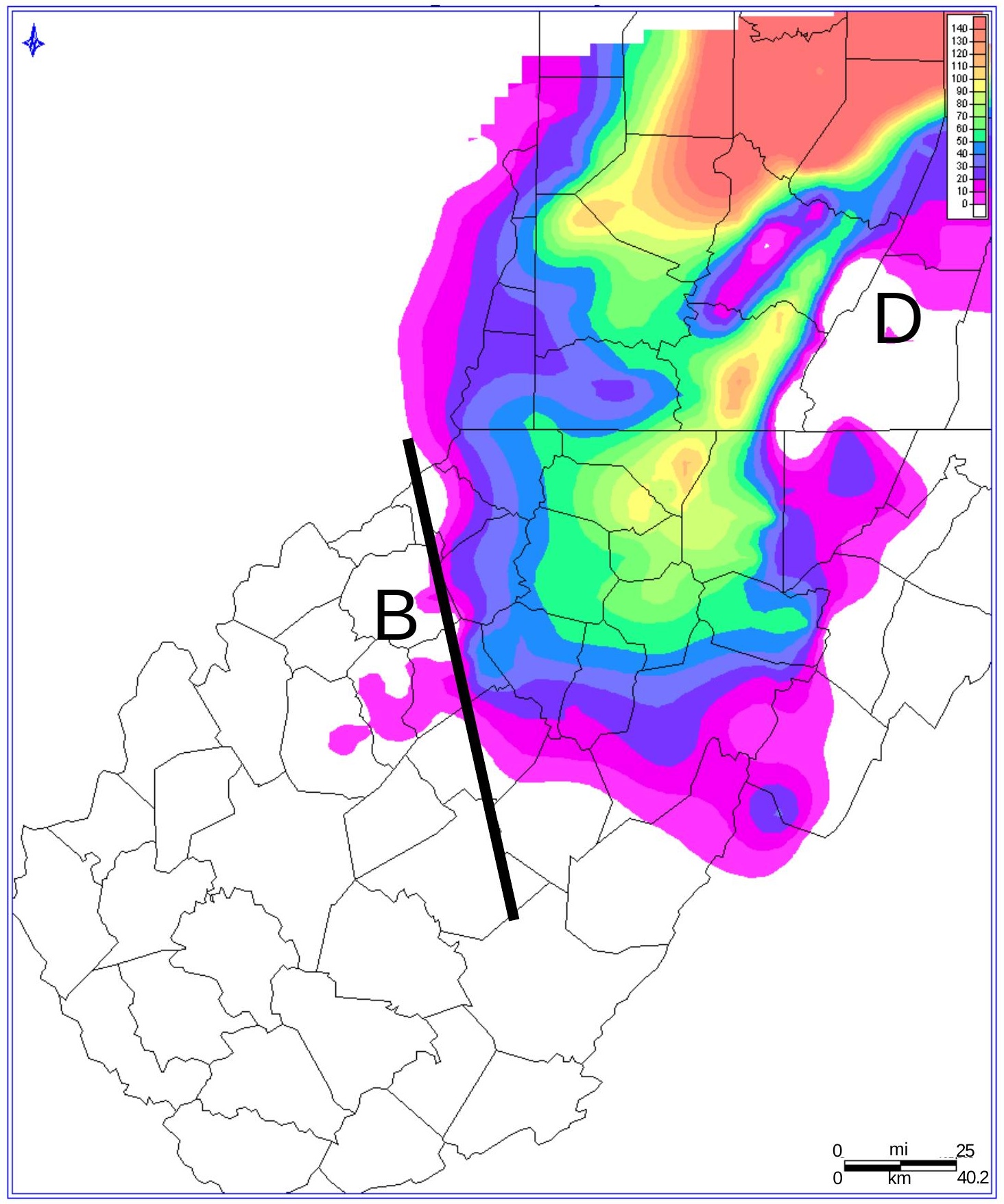

Figure 2-14. Isopach of the Tully Limestone showing decreases in thickness to the south and east. The Tully is thickest to the north coinciding with the thinning of the underlying Mahantango Shale (Figure 2-13) and the Tully is absent where the Mahantango is thickest (D). The southern extent of the Tully Limestone is marked by a northwest to southeast trend in the same geographic area as recognized in the underlying Marcellus and Mahantango (Figures 2-10, 2-11, 2-12, 2-13). 


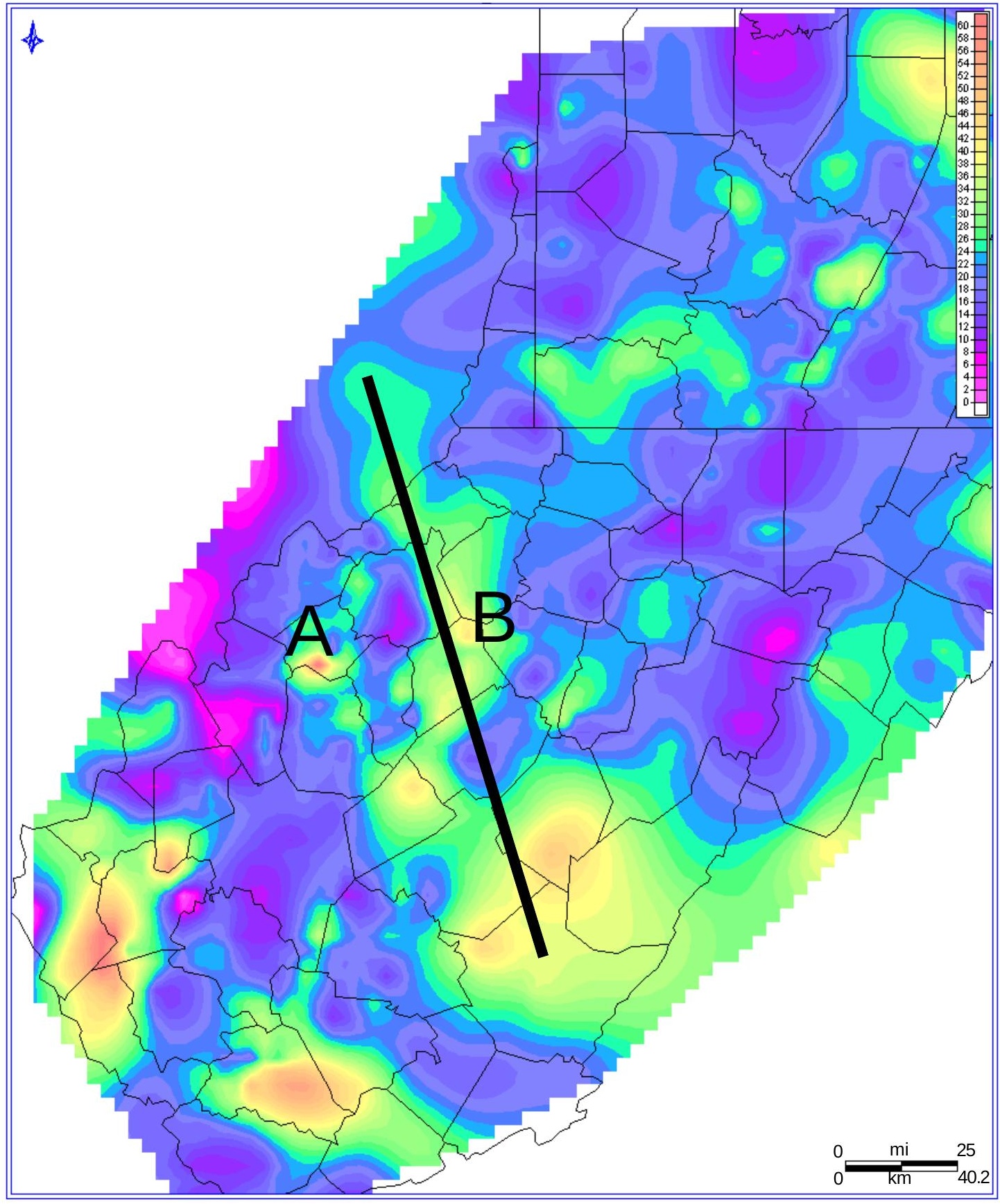

Figure 2-15. Isopach of the Harrell Shale illustrating a thick in north-central West Virginia. There is a rapid change in thickness in the Harrell (B) that is recognized in the underlying Tully, Mahantango, and Marcellus (Figures 2-10, 2-11, 2-12, 2-13, 2-14). 


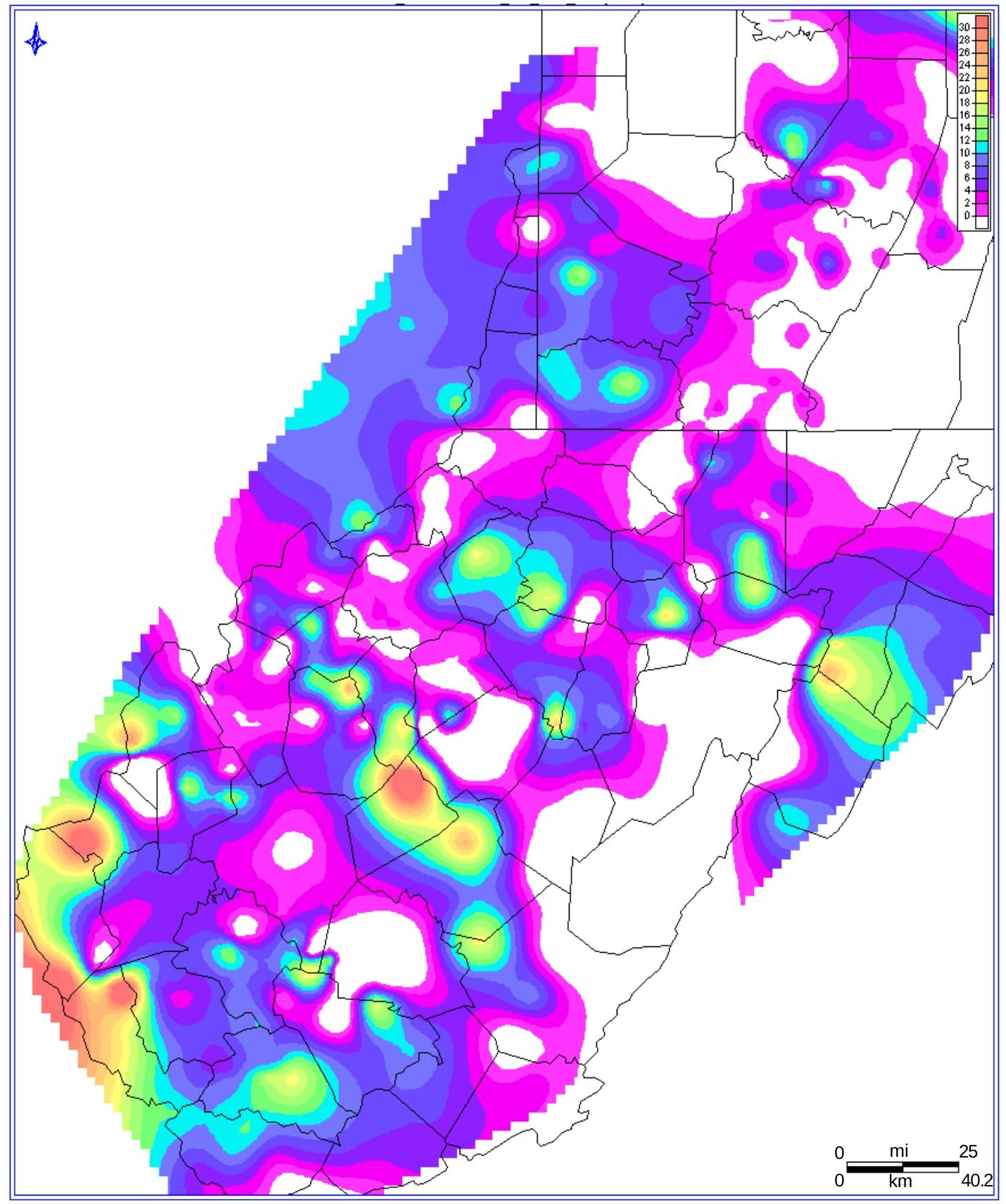

Figure 2-16. Isopach of the thickness of Harrell Shale with gamma ray values greater than 230 API was constructed showing the thick potentially gas-rich intervals running in an arc through central West Virginia into the northern panhandle and extreme southwest Pennsylvania and is offset from the thick in the underlying Mahantango Shale (Figure 213). 


\subsection{CONCLUSIONS}

In the Appalachian basin, the Middle Devonian organic-rich shale interval, including the Marcellus Shale can be defined and mapped using electric log characteristics tied to core data. The Marcellus Shale is defined in the subsurface by a gamma-ray exceeding 200 API, and a bulk density of less than 2.55 g/cc. The Marcellus Shale has relatively high quartz and significant pyrite contents. The pyrite and gas contents in the organic rich shale intervals can exert a strong influence on lithologic analysis of the Marcellus and other Middle Devonian shale units. A methodology is proposed using the correlation of higher organic content with higher Uranium content as recognized with the spectral gamma-ray data. Better definition of interval of higher gas potential (free and bound) in the Marcellus, Mahantango, and Harrell shale units is possible by coupling higher uranium content with lower bulk density. Using the uranium content as measured by the spectral gamma-ray log, modified Archie equation and Simandoux shale correction are proposed that may provide more accurate values for water and gas saturations in the Middle Devonian organic-rich shale units of the Appalachian basin.

Using explicitly defined log criteria the distribution of Middle Devonian units can be mapped in the subsurface across West Virginia and southwest Pennsylvania. The distribution of thickness and organic-richness of these units, including the Marcellus Shale, shows persistent trends that appear to be related to reactivation of the Rome Trough and to a northwest-southeast trend in central West Virginia. The thickness of organic potentially gas-rich zones in the Marcellus and Harrell shale units can be identified by mapping gamma ray values exceeding 230 API units. Spatial changes in 
thickness and organic-richness in the Marcellus Harrell shale units and the distribution of Middle Devonian limestone units (Purcell and Tully) may be better explained by fluctuations in localized anoxic environments, rather than widespread synchronous stratified anoxic bottom waters. These techniques of identifying lithology and relatively thick intervals of potential organic-rich Middle Devonian shale may assist in better identifying areas of higher exploration potential and to target zones for fracture stimulation or to land a horizontal leg. 


\subsection{REFERENCES CITED}

Anderson, R. J., Avery, K.L., and others, 1984, American Association of Petroleum Geologists Correlation Chart; Series 1984.

Bohacs, K., MacQuaker, J., Lazar, O. R., Jonk, R., Hemmesch, N., Cassel, E. J., Detailed Anatomy of Parasequences in Mudstone-Dominated, Allegedly Anoxic Settings: Examples from the Cretaceous Mowry Shale and Associated Formations, Western U.S., AAPG Annual Convention and Exhibition, Denver, Colorado, June 7-10, 2009.

Brett, C.E., and Ver Straeten, C.A., 1994, Stratigraphy and facies relationships of the Eifelian Onondaga Limestone (Middle Devonian) in western and west central New York State; Field trip guidebook; New York State Geological Association; 66th annual meeting: Guidebook - New York State Geological Association, Meeting, v. 66, p. 221270.

Demaison, G.J., and Moore, G.T., 1980, Anoxic environments and oil source bed genesis: AAPG Bulletin, v. 64, p. 1179-1209.

Dennison, J. M., J. K. Filer, and T. J. Rossbach, 1996, Devonian strata of southeastern West Virginia and adjacent Virginia, in Dennison, J. M., ed., Geologic field guide to Devonian hydrocarbon stratigraphy of southeastern West Virginia and adjacent Virginia, United States (USA), Appalachian Geological Society, Charleston, WV, United States (USA).

Duke, W.L., Prave, A.R., Al-Hajri, S., Cuffey, C.A., Ericksen, M.C., Fisler, D.K., Guebert, M.D., Matthews, J.C., Narehood, S.E., Ritter, J.B., and Vogel, K.R., 1991, Storm-and tide-influenced prograding shoreline sequences in the Middle Devonian Mahantango Formation, Pennsylvania; Clastic tidal sedimentology: Memoir - Canadian Society of Petroleum Geologists, v. 16, p. 349-369.

Cubitt, J. M., P. H. Heckel, A. G. DelSignore, and M. Wooldridge, 1978, The Tully Limestone of central New York; stratigraphy and facies variation, Guidebook - New York State Geological Association, Meeting, no. 50, p. 273-281.

Ettensohn, F.R., 1998, Compressional tectonic controls on epicontinental black-shale deposition; Devonian-Mississippian examples from North America, in Schieber, J., Zimmerle, W. and Sethi, P.S., eds., Shales and mudstones; I, Basin studies, sedimentology, and paleontology: Federal Republic of Germany (DEU), E. Schweizerbart'sche Verlagsbuchhandlung Naegele u. Obermiller, Stuttgart, Federal Republic of Germany (DEU), . 
Ettensohn, F.R., and Barron, L.S., 1982, A tectonic-climatic approach to the deposition of the Devonian-Mississippian black-shale sequence of North America; Proceedings of the 1982 Eastern oil shale symposium: Proceedings - Eastern Oil Shale Symposium, v. 1982, p. 5-37.

Gold, R, 2008, Gas Producers Rush to Pennsylvania: Promising Results There Spur Investment; The Wall Street Journal. page A2.

Hasson, K.O., and Dennison, J.M., 1988, Devonian shale lithostratigraphy, Central Appalachians, U.S.A; Devonian of the world; proceedings of the Second international symposium on the Devonian System; Volume II, Sedimentation: Memoir - Canadian Society of Petroleum Geologists, v. 14, p. 157-177.

Heckel, P. H., 1969, Devonian Tully Limestone in Pennsylvania and comparison to type Tully Limestone in New York, 33 pp.

King, H. M., 2008, Marcellus Shale Gas: New Research Results Surprise Geologist! www.Geology.com

Linsley, D.M., 1991, Coarsening-up cycles and stratigraphy of the upper part of the Marcellus and the Skaneateles Formation in central New York; Dynamic stratigraphy and depositional environments of the Hamilton Group (Middle Devonian) in New York State, Part II: Bulletin New York State Museum (1976), v. 469, p. 75-92.

Macquaker, J., McIlroy, D., Davies, S. J., Keller, M. A., Not Anoxia! How Do You Preserve Organic Matter Then? AAPG Annual Convention and Exhibition, Denver, Colorado, June 7-10, 2009.

Nyahay,R., Leone, J., Smith, L.B., Martin, J.P. and Jarvie, D.J., Update on Regional Assessment of Gas Potential in the Devonian Marcellus and Ordovician Utica Shales of New York, 2007 AAPG Eastern Section Meeting, September 16-18, Lexington, Kentucky, http://www.searchanddiscovery.net/documents/2007/07101nyahay/index.htm

Ward, J, Log Analysis of Legacy Marcellus Borehole Logs, AAPG Eastern Section Meeting, Pittsburgh, Pennsylvania, 2008

Woodrow, D.L., Dennison, J.M., Ettensohn, F.R., Sevon, W.T., and Kirchgasser, W.T., 1988, Middle and Upper Devonian stratigraphy and paleontology of the central and southern Appalachians and eastern Midcontinent, U.S.A; Devonian of the world; proceedings of the Second international symposium on the Devonian System; Volume I, Regional syntheses: Memoir - Canadian Society of Petroleum Geologists, v. 14, p. 277-301. 
3.0 The Depositional Dynamics of the Middle Devonian Marcellus Interval Using a Petrophysical and Stratigraphic Analysis of the Sub-surface in West Virginia and Southwestern Pennsylvania

\author{
Boyce, Matthew L \\ Department of Geology and Geography \\ West Virginia University \\ 98 Beechurst Avenue, 330 Brooks Hall \\ Morgantown, WV 26505 \\ E-mail: $\underline{\text { mboyce5@mix.wvu.edu }}$ \\ Carr, Timothy $\mathbf{R}$ \\ Marshall Miller Professor of Geology \\ West Virginia University \\ 98 Beechurst Avenue, 330 Brooks \\ Morgantown, WV 26505 \\ E-mail: tim.carr@mail.wvu.edu \\ Singh, Vivek \\ West Virginia University \\ Department of Physics \\ PO Box 6315 \\ Morgantown, WV 26505 \\ E-mail: Vivek.Singh@mail.wvu.edu
}

\title{
3.1 ACKNOWLEDGEMENTS
}

We would like to first thank Consol Energy and EQT for providing a large amount of raster well data as well as multiple digital files and core samples. We would also like to extend thanks to the National Energy and Technology Lab (NETL) of the Department of Energy (DOE) for support of the project and access to facilities for this study. Finally, we would like to thank Professor Mohindar Seehra of the physics department at WVU who supervised the work of Dr. Vivek Singh on performing the XRD and TOC analysis. 


\subsection{ABSTRACT}

The Middle Devonian interval of the central Appalachian basin is a complex stratigraphic sequence of carbonate, siliciclastic and organic-rich mudstone units with economically important shale gas intervals (e.g., Marcellus Shale). To better understand controls on deposition, sub-surface stratigraphic criteria for individual units were rigorously defined with petrophysical parameters tied to core samples for a large number of wells $(1,607)$. The mapping of the units in the Middle Devonian interval identified persistent trends that influenced the depositional patterns throughout the Middle Devonian. Regional trends and localized paleotopography are controlled by the structure and the first pulses of the Acadian Orogeny. Regional and localized paleotopography is recognized by rapid changes in thickness, lithology, and organic content. Changes in topography influenced thickness and also enhanced production, accumulation and preservation of organic material in topographic lows for all the stratigraphic units. Regionally, a persistent slope-break environment enhanced organic matter production and preservation, possibly from seasonal upwellings. The estimation of organic richness for the Marcellus and other Middle Devonian units was accomplished using well log analysis techniques on standard well log curves (i.e. gamma ray, bulk density). The identification of this relationship is tied to depositional patterns by identifying trends such as areas along changes in paleo-slope and localized structures where organic material was generated in sufficient quantities to facilitate preservation. The best areas for gas shale from the perspective of organic content were identified not by the gross unit thickness of the shale but by the relation to the underlying structure at the time of deposition. 


\subsection{INTRODUCTION}

Recently in the United States, the Middle Devonian of the Central Appalachian basin has become a major focus of natural gas exploration, specifically the black, organic-rich shale units such as the Marcellus Shale. Until the application of improved completion tactics (e.g., fracture stimulation and horizontal drilling), Appalachian black shale units have had a long history of marginal gas production (King, 2008). Because of the increased potential for production from gas shale, recent estimates of recoverable gas have been rising. By some estimates, the Marcellus alone can contain 1,307 trillion cubic feet of recoverable gas (37,511 billion $\mathrm{m}^{3}$ ) (Gold, 2008).

Surface studies of the Middle Devonian interval in the Appalachian basin have focused on outcrops in New York and north central Pennsylvania (Ettensohn, 1998; Brett and Ver Straeten, 1994; Linsley, 1991). Published subsurface studies have used only a limited set of geophysical log characteristics with relatively loosely defined petrophysical criteria (e.g., unscaled gamma-ray only approach of Lash and Engelder, 2009). In West Virginia and southwest Pennsylvania, recent work has attempted to better define the stratigraphy and depositional characteristics in the sub-surface by using multiple geophysical logs tied to core in order to rigorously define petrophysical criteria for each stratigraphic interval (Boyce and Carr, 2009). In this paper, we use previously defined petrophysical criteria tied to core samples within a digital data-set of over 1,607 wells

distributed across approximately 23,500 $\mathrm{mi}^{2}\left(60,839 \mathrm{~km}^{2}\right)$ in the Central Appalachian basin to examine the Middle Devonian regional stratigraphy and depositional history in the sub-surface (Figure 3-1). The results better define the distribution of Middle Devonian stratigraphic units across the study area and reveal possible controls on the 
accumulation of organic-rich shale units. Based on this understanding, a more accurate assessment of the hydrocarbon potential of the Marcellus Shale and related Middle Devonian organic-rich shale units in the Appalachian basin can be estimated.

During the Middle Devonian, the paleo-geographic features surrounding the study area were the Acadian Mountains, Cincinnati Arch and Rheic Ocean (Figure 3-2). The positioning of these paleo-geographic features is significant because they created a shallow marine basin potentially restricting circulation. The Middle Devonian is the first pulse of the Devonian-Mississippian worldwide anoxic event in the Central Appalachian basin (Ettensohn, 1998). Previous studies suggested that the black shale units in the Appalachian basin represent a deepening foreland basin that tie to Acadian tectonic pulses and the occasional limestone units correlate to shallowing-upward basin sequences (Ettensohn, 1998). Recently, others have suggested that during the Devonian in the Appalachian basin, the bottom waters were not synchronously anoxic and could be comparatively shallow within wave base of strong storms (Schieber, 1994, 1998). Deposition and accumulation of mud rocks has been shown to be a dynamic and complex process producing localized anoxic environments that allowed for high amounts of organic matter to be preserved (e.g., Maquaker and others, 2009, Bohacs and others, 2009). Boyce and Carr (2009) emphasized the idea of localized anoxic environments for the Marcellus Shale to explain rapid changes in thickness and organic richness over comparatively small areas.

Previous work on the Middle Devonian interval in the central Appalachian basin has focused primarily on the depositional characteristics in outcrop. Comprehensive studies on the subsurface relationships and petrophysics of the Middle Devonian interval 
are lacking in southwestern Pennsylvania and West Virginia (Ettensohn, 1998). The Middle Devonian stratigraphic succession in the study area is as follows in ascending order: the Onondaga Limestone (Eifelian), Marcellus Shale (Eifelian), Purcell Limestone (Eifelian), Mahantango Shale (Givetian), Tully Limestone (Givetian), and Harrell Shale (Fransnian-Givetian) (Anderson et.al, 1984, Hasson and Dennison, 1988; Duke and Prave, 1991)(Figure 3-3). Defined petrophysical criteria were used to recognize these stratigraphic intervals of the Middle Devonian and map the lithostratigraphic relationships in the subsurface to better understand the depositional environments. Log and core analysis were implemented to better define lithology and the oxic and anoxic relationships of the interval and their relationship to organic richness. An additional goal was to create a regional geologic model to describe the depositional history of the entire interval in the study area and then utilize this to evaluate the economic potential of organic-rich Middle Devonian shale units in the central Appalachian basin. 


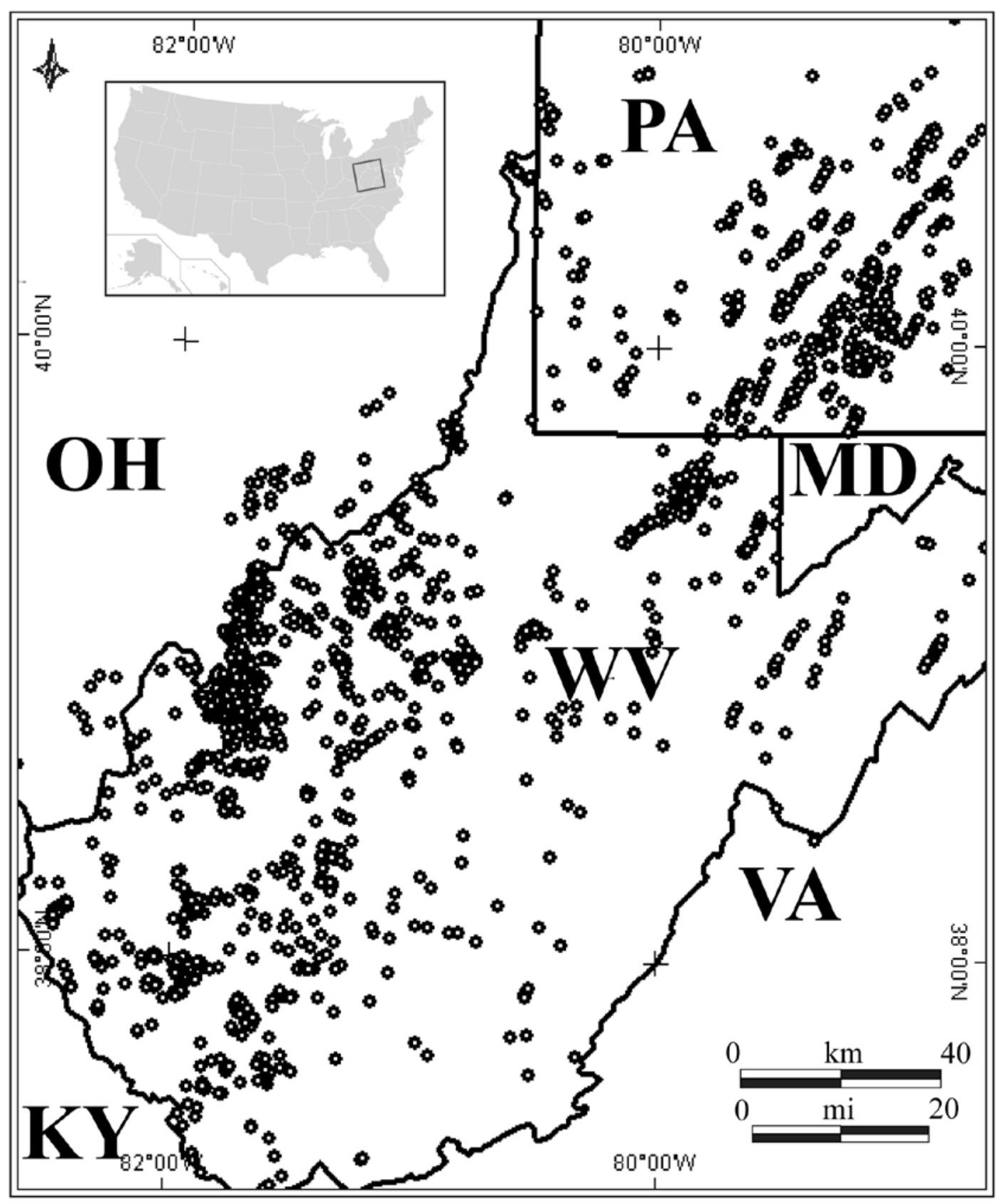

Figure 3-1. The study area encompasses the state of West Virginia (WV) and southwest Pennsylvania (PA). It is located in the Appalachian geological province in the central Appalachian basin and covers an area of approximately 23,500 $\mathrm{mi}^{2}\left(60,839 \mathrm{~km}^{2}\right)$. A total of 1,607 wells were correlated and are illustrated on the map (black circles). Selected wells in Ohio were examined to verify specific depositional trends. 


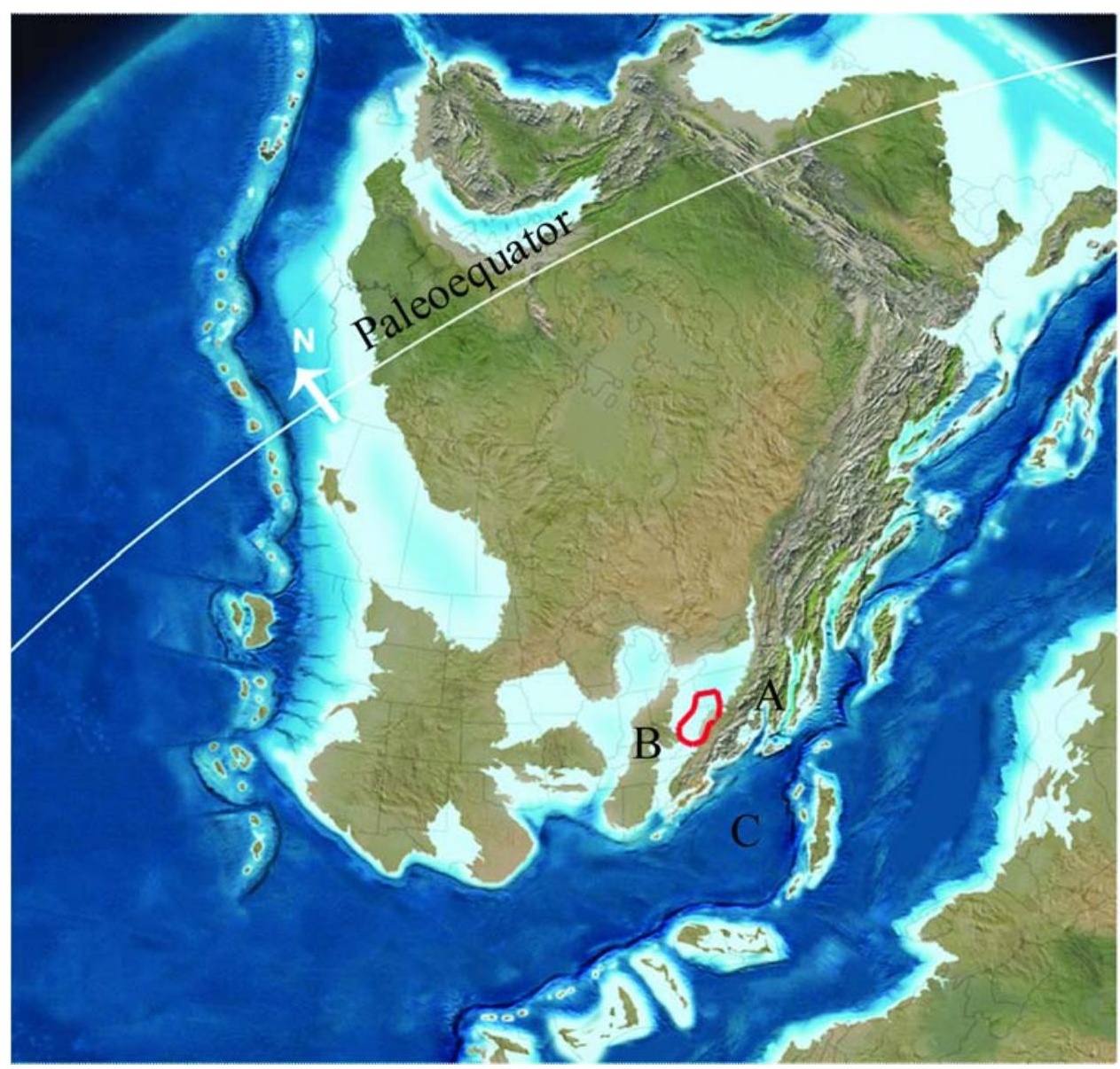

Figure 3-2. The study area is outlined in red on the paleogeographic interpretation of the Middle Devonian (385 Ma). The paleogeographic features that surround the study area are the Acadian Mountains (A) to the east, the Cincinnati Arch (B) to the west and Rheic Ocean (C) to the south. Modified from Blakey (http://jan.ucc.nau.edu/ rcb7/RCB.html). 


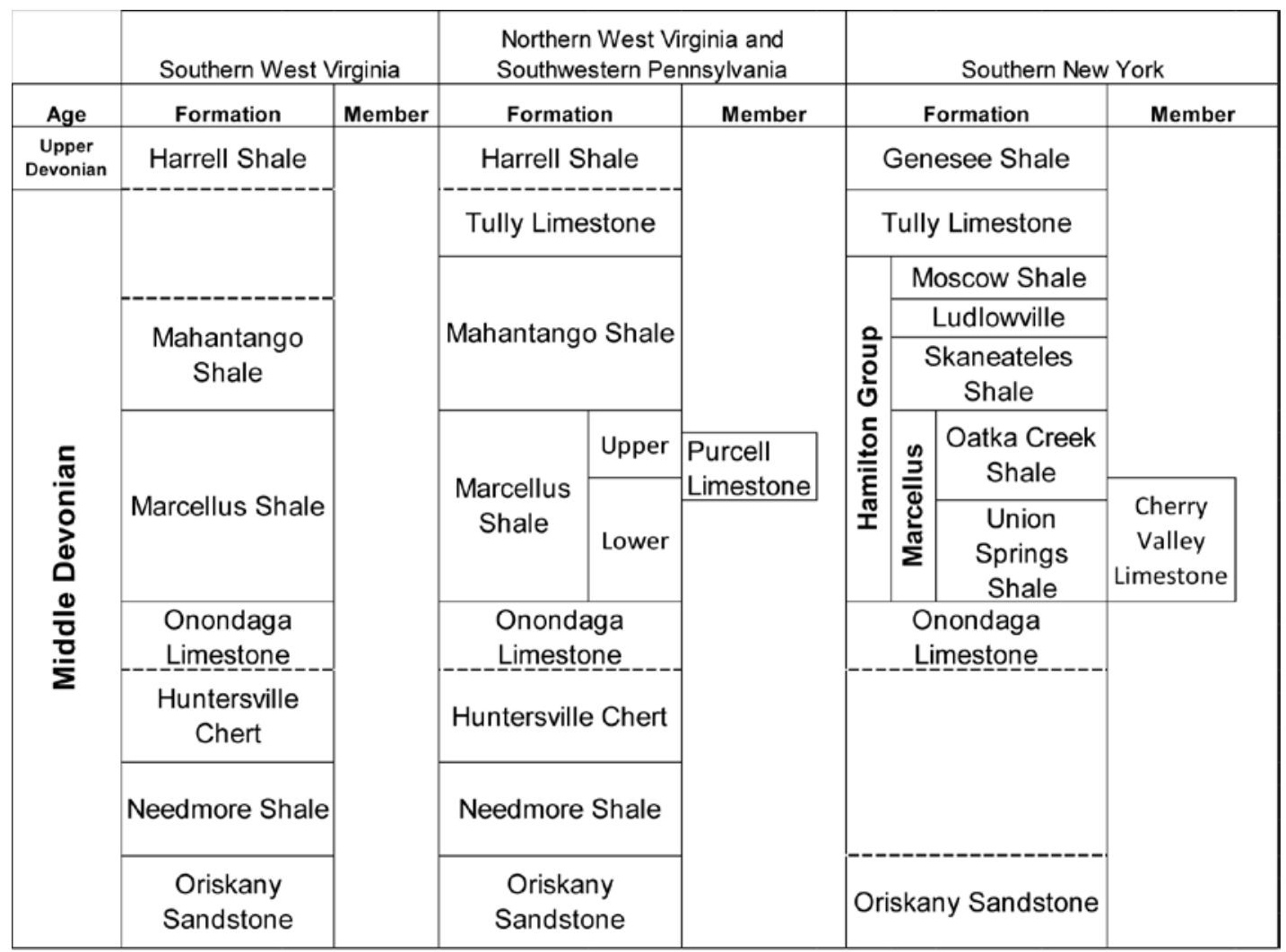

Figure 3-3. Stratigraphic column for the study area compared to the time equivalent units in southern New York. While many of the units in the study area have the same nomenclature as the strata in New York, it is important to recognize there are different formations and stratigraphic relationships in relation to the geography. The units that are the subject of this study are in the two columns labeled southern West Virginia and northern West Virginia and southwestern Pennsylvania. Compiled from Anderson et. al.(1984), Hasson and Dennison (1988), and Swezey (2002). 


\subsection{METHODOLOGY}

Data were acquired from a variety of sources and consist of core samples, well logs, and core analyses. A total of 35 core plugs for the Marcellus Shale and related Middle Devonian units were acquired and analyzed for mineralogy (X-ray diffraction) and total organic carbon (pyrolysis) (Table 3-1). In total, 1607 well logs were acquired and used for the study area. These wells were imported into IHS Petra® and then correlated using the cross-section and correlation modules. The well log curves available for correlation included resistivity, conductivity, spectral gamma ray suite, neutron porosity, bulk density, photo electric (PE), gamma ray, caliper, and spontaneous potential curves. The formation tops identified were then used to create isopach maps using the gridding function in the IHS Petra ${ }^{\circledR}$ map module. Grid sizes varied depending on data density and range from one square mile $\left(2.6 \mathrm{~km}^{2}\right)$ to three square miles $\left(7.8 \mathrm{~km}^{2}\right)$. To evaluate well log characteristics over the region, 458 well logs were digitized. The cores, rock analysis, isopach maps, and petrophysical characteristics were integrated and used to better understand the depositional history of the Middle Devonian Marcellus Shale interval in West Virginia and southwestern Pennsylvania. Several key parameters for the Marcellus Shale and related Middle Devonian deposits were determined and mapped across the study area. These parameters include: stratigraphic unit thickness, lithology, and estimates of total organic carbon (TOC) and free gas fraction. There are other important reservoir parameters such as adsorbed gas fraction and permeability (matrix and induced or natural fractures), which are beyond the scope of this paper. 


\subsection{Definition of Subsurface Stratigraphic Units}

Previously, sub-surface definitions used to define the Middle Devonian stratigraphic units including the Marcellus Shale have been loosely defined primarily using the gamma ray curve (e.g., Lash and Engelder, 2009). While the gamma ray log is widely available, it should not be used singularly to constrain the lithostratigraphic boundaries of stratigraphic units. We have found that in the study area, using the gamma ray, bulk density, and PE tool more tightly constrain the criteria by tying the stratigraphic characteristics to the units in question. Another issue to address is the stratigraphic nomenclature for the New York and northern Pennsylvanian section are often carried down to the study area, which creates stratigraphic confusion. For example, the Hamilton Group exists in New York and includes the Moscow, Ludlowville, Skaneateles, and Marcellus Shale. This contrasts with the section in the study area where there is no formal Hamilton Group and the Mahantango is deposited, rather than the Moscow, Ludlowville, and Skaneateles Formations. This is important because if the assumed lithologic characteristics do not correlate from the outcrop in New York to the sub-surface in the study area, then the regional depositional model significantly changes. Therefore to create consistency we suggest using the formal names for the study area which are highlighted in Figure 3-3.

In the subsurface, the Onondaga Limestone is a fine-grained limestone that rests unconformably on the Needmore Shale, Huntersville Chert, or Oriskany Sandstone (Figure 3-3). Because it is a limestone, the gamma ray response for the Onondaga is approximately 30-110 API but more importantly, the PE value will be approximately 5 (i.e. 5.14 barns/electron is limestone)(Figure 3-4, Table 3-1). The different lithologies 
below the Onondaga allow for the PE tool to be used to pick the base of the Onondaga. Occasionally, the base of the Onondaga is marked with a hot gamma ray unit. It exists in the northeast of the study area and appears to correlate to the Needmore Shale in outcrop in western Maryland. This unit will be discussed as the Needmore Shale in this study and can be defined as having a gamma ray value at the base of the Onondaga that is greater than 150 API (Figure 3-4, Table 3-1).

In outcrop and core, the Marcellus Shale is a dark, black to gray organic rich fissile shale with large amounts of pyrite. In the subsurface we define it as having a gamma ray value greater than 200 API and a bulk density value of less than $2.55 \mathrm{~g} / \mathrm{cc}$ (Figure 3-4, Table 3-1). The significantly lower density values in the Marcellus are due to higher TOC and gas content which contrast sharply with the underlying and overlying strata. The only formal member of the Marcellus is the Purcell Limestone, which is a fine grained limestone in core and outcrop. When present, the Purcell informally separates the Marcellus into an upper and lower unit. Because it is a limestone encased in black shale, the Purcell can be readily identified with a gamma ray value less than 200 API, a PE value of approximately 5 barns/electron, and a density value closer to $2.71 \mathrm{~g} / \mathrm{cc}$ (Figure 34, Table 3-1).

Overlying the Marcellus is the Mahantango Formation. Where it outcrops in eastern West Virginia, the Mahantango is gray shale with occasional thin limestone beds. Moving north in the outcrop belt from eastern West Virginia to central Pennsylvania, the Mahantango increases in depositional complexity and thickness. It is a complex stratigraphic unit that can have a variety of facies and lithologies including laminated marine shale beds, black shale beds, siltstone units, very fine to coarse sandstone units, 
conglomerates, and limestone units (typically fine-grained limestone but can have occasional coral reefs or biostromes in outcrop).Even though the Mahantango is a complex unit, it can be readily identified due to the contrasting strata above and below. The basal boundary sharply contrasts the mineralogic components of the Marcellus, which on average has more TOC and higher amounts of pyrite. The upper boundary of the Mahantango is clearly seen by the changing lithology from a siliciclastic to a limestone. Therefore the Mahantango can be defined as having a gamma ray value less than 200 API and a bulk density greater than $2.55 \mathrm{~g} / \mathrm{cc}$ (Figure 3-5, Table 3-1).

The Tully is a fine grained limestone that overlies the Mahantango and can be clearly identified by the contrast in gamma ray and the PE tool. The gamma ray value will be clean (approximately 30-110 API) and the PE value will be approximately 5barns/electron, which contrasts nicely to the underlying and overlying siliciclastics (Figure 3-5, Table 3-1).

The final unit in the sequence is the Harrell Shale. Like the Marcellus it is a dark, black organic rich shale in outcrop and the sub-surface. The rock characteristics (i.e. high TOC and Pyrite) also influence how the Harrell is defined by having a gamma ray value greater than 200 API and a bulk density of less than 2.55 g/cc (Figure 3-5, Table 3-1). The petrophysical criteria used to constrain the stratigraphic units in the sub-surface are summarized in Table 3-3.

\subsection{Core Analysis}

The percentages of various crystalline minerals in the core samples were determined using powder $\mathrm{x}$-ray diffraction (XRD) done at room temperature (Rigaku 
diffractometer, $\mathrm{Cu}-\mathrm{K}_{\alpha}$ radiation of wavelength $=0.154185 \mathrm{~nm}$ ). The quantitative analysis of the XRD patterns for determining the percentage of various minerals were undertaken using the ICDD data-base, Jade 9 software and Rietveld analysis. While there is a fair amount of variance, results of lithologic analysis show that the Marcellus is composed of a large amount of quartz and a relatively low concentration of clay, primarily illite(Figure 3-6). Complete results are present in Table 3-2.

The results from the whole rock analysis also highlight the high amount and wide range of TOC present in the Marcellus (5-20\%)(Table 3-3). Also the pyrite content can be relatively large, ranging from 2 to $8 \%$ (Table 3-3). Because of the large amount of pyrite and TOC present, the whole rock mineralogy was compared to the well log mineralogical analysis using a RHOmaa-Umaa plot (Figure 3-7). The well logs used to create this plot are the bulk density tool, which is used for RHOmaa, and the bulk density multiplied by the photo electric (PE) curve to calculate Umaa. The XRD results plot well on the mineralogical triangle, whereas the log data plots up and to the right, away from the XRD results (Figure 3-7). The well log data plots above the XRD results because the TOC or gas in the rock causes the rock density (i.e. RHOmaa) to be lighter. The Umaa value plots to the right because of the pyrite present in the rock. Even though there is a small amount of pyrite, the larger number of electrons associated with the iron in pyrite will severely affect the PE tool. This causes the Umaa shift to the right. This relationship must be taken into consideration with other petrophysical analyses and depositional relationships.

The percent of total organic carbon (TOC) in each sample was determined using thermogravimetry (TG). In TG (Mettler Model TG50), a sample hanging in a sensitive 
balance is heated in air at a constant heating rate of $10^{\circ} \mathrm{C} /$ minute up to $650^{\circ} \mathrm{C}$ and held at $650^{\circ} \mathrm{C}$ for another 20 minutes. It was found that for most samples, change in the weight of a sample due to burning of the organic carbon occurred between the temperatures of $400^{\circ} \mathrm{C}$ and $550^{\circ} \mathrm{C}$. The percent of TOC was then determined from this percentage change in the weight of the samples. The changes in weight due to the presence of moisture of about 1 to $2 \%$ were complete by about $150^{\circ} \mathrm{C}$. Finally, the percent of different minerals determined from XRD-Rietveld analysis were then renormalized so the percentage of minerals plus TOC and moisture add up to $100 \%$.

\subsection{Spectral Gamma Ray Log Analysis}

Well-logs have been used for a number of decades to identify and quantify organic-rich rocks and have been extended with pulsed-neutron spectral logs and geochemical logging (e.g. Schlumberger ${ }^{\mathrm{TM}}$ elemental capture spectroscopy). A common petrophysical property used to evaluate organic-rich shale units is the high gamma-ray value which is attributed to uranium associated with the organic matter (Beers, 1945; Swanson, 1966; Passey and others, 1990). A relationship between total gamma-ray intensity and organic richness was proposed for Devonian shale units in the Appalachian basin (Schmoker, 1981). The gamma-ray spectral logging tool measures the abundances of the three most common naturally occurring radioactive elements: thorium (Th), uranium (U), and potassium (K). Because of the observed relationship between uranium and organic matter, the gamma-ray spectral log has been suggested as a method to identify and quantify organic richness (Fertl and Rieke, 1980). However, gamma-ray can significantly over- or under-estimate organic matter in intervals unless calibrated within a local area (Schmoker, 1981, Passey and others, 1990). As kerogen is less dense 
than the surrounding rock matrix, the density log responds to the concentration of organic matter (Passey and others 1990). However the density log is very sensitive to borehole conditions and must be used in combination with the caliper log to determine borehole washouts which affect this pad tool. The photoelectric index (PE) is a supplementary measurement of density logging tools and records the absorption of low-energy gamma rays. The logged value is a direct function of the aggregate atomic number of the elements in the formation and is a sensitive indicator of mineralogy, especially of iron bearing minerals such as pyrite. We have found that in the study area, the gamma ray and spectral gamma ray (when available and calibrated locally with bulk density (RHOB) and photoelectric (PE) logging tools) can be used to more tightly constrain the criteria by tying the lithologic characteristics to the Middle Devonian units in question (Table 3-1).

A correlation of higher gamma-ray intensity and, in particular, the concentration of uranium (U) to increased amounts of TOC in the Marcellus and related Middle Devonian units has been observed in previous studies (Schmoker, 1981; Fertl and Rieke, 1980; Boyce and Carr, 2009). In this study, this relationship appears to hold throughout the study area and provides a proxy to quantify areas of increased TOC accumulation. Using a consistent inverted scale for the uranium $(0-80 \mathrm{ppm})$ and bulk density (3.0 to $0.0 \mathrm{~g} / \mathrm{cc}$ ), zones in individual wells with significant gas potential are highlighted by a cross-over (Boyce and Carr, 2009; Figure 3-8). In summary, higher uranium values provide a good measure of higher TOC and appear to be empirically related to higher potential gas content. Using the uranium content, as measured by the spectral gamma-ray tool, can improve understanding of the depositional controls on the stratigraphic and 
spatial distribution of these higher TOC intervals during the Middle Devonian of the Appalachian basin and can assist in understanding gas production trends.

Although the spectral gamma ray tool is an extremely useful tool, it is not run as common practice in wells targeting the Middle Devonian shale units in the Appalachian basin. Using the fifteen available spectral gamma-ray logs scattered across the study area, a relationship for measured uranium (ppm) and the standard full-spectrum gamma ray (API) was developed. The relationship between the two curves is polynomial and the uranium values can be calculated using the standard gamma ray within a ten percent error (Figure 3-9). The estimated uranium logs were calculated for all the wells in the study area.

The spectral gamma ray logs were used in other aspects of petrophysical analysis, specifically the ratio of thorium and uranium (Adams and Weaver, 1958). The ratio of thorium and uranium from the spectral gamma ray suite, has been linked with depositional environment and can be used to identify oxidizing and reducing conditions. This is particularly useful when investigating the Mahantango and Marcellus units. In the Mahantango, there are occasional black shale beds and more coarse siliciclastics. The thorium-uranium ratio illustrates that the oxidizing conditions of the Mahantango varied widely in relation to the black shale and the coarser siliciclastic units (Figure 3-10). This suggests that the influence of sedimentation and geochemical conditions could have controlled whether the system was anoxic or oxic during deposition and that bottom waters may not have been synchronously anoxic. 


\begin{tabular}{|c|c|c|c|}
\hline \multicolumn{5}{|c|}{ Defining Characteristics } \\
\hline Stratigraphic Unit & Gamma Ray & PE Value & Bulk Density \\
\hline Needmore Shale & Aprox. > 150 API & N/A & Aprox. 2.71 \\
\hline Onondaga Limestone & Clean (30 - 110 API) & Aprox. 5 & 2.71 \\
\hline Marcellus Shale & $>200$ API & N/A & $<2.55$ \\
\hline Purcell Limestone & $<200$ API & Aprox. 5 & 2.71 \\
\hline Mahantango Shale & $<200$ API & N/A & $>2.55$ \\
\hline Tully Limestone & Clean (30 - 110 API) & Aprox. 5 & 2.71 \\
\hline Harrell Shale & $>200$ API & N/A & $<2.55$ \\
\hline
\end{tabular}

Table 3-3. Summary of the defining characteristics for the subsurface stratigraphic units in the study area. 


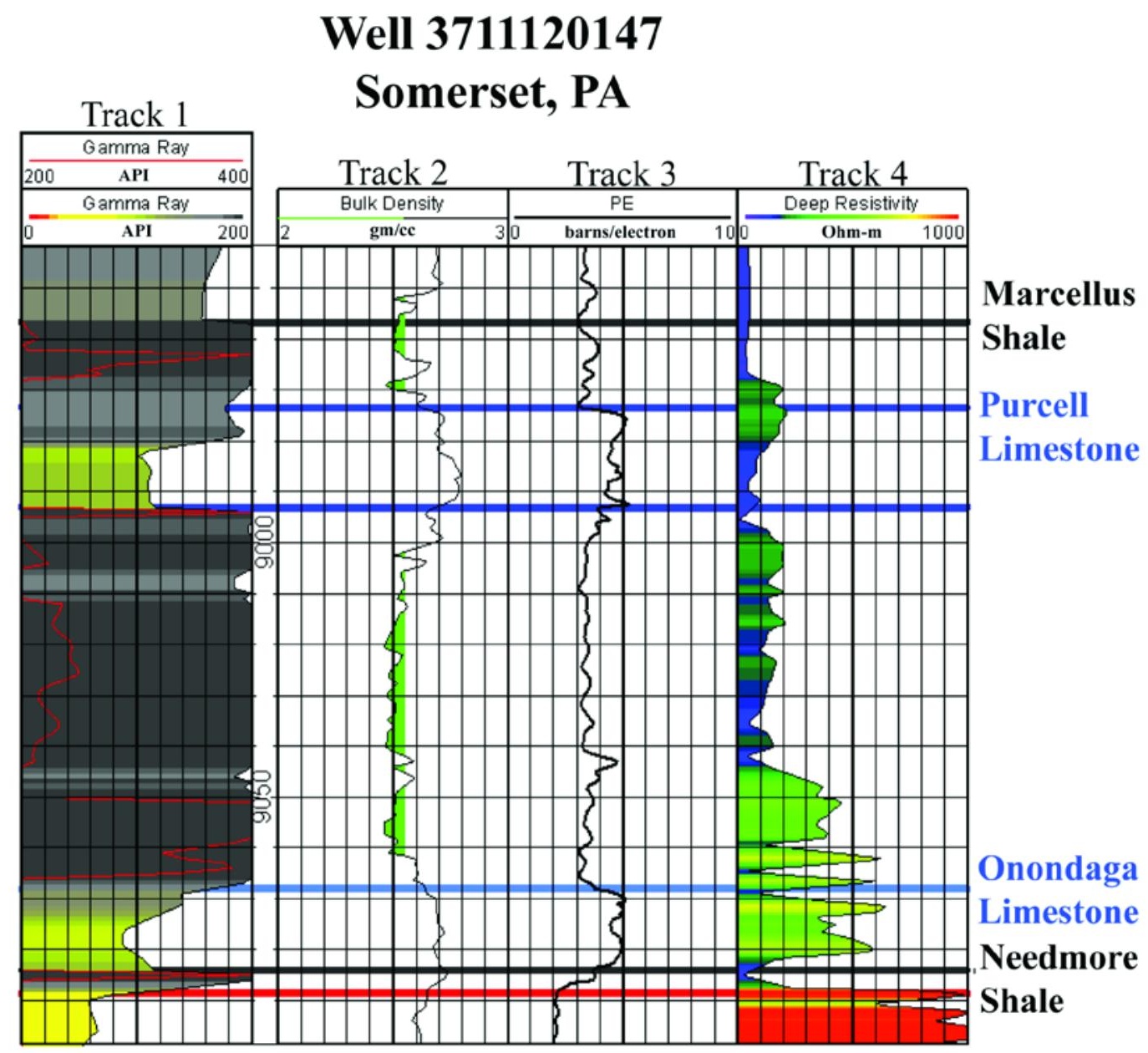

Figure 3-4. Type log for the Marcellus, Purcell, Onondaga, and Needmore units in southwest Pennsylvania and West Virginia. The gamma ray curve is plotted on Track 1 and ranges from 0 - 200 API. When the gamma ray exceeds 200 API it wraps around and is outlined in red. The bulk density is plotted in Track 2 and is shaded green for bulk density values less than $2.55 \mathrm{~g} / \mathrm{cc}$. The photo electric (PE) curve is plotted on Track 3 and ranges from 0-10 barns/electron. The resistivity curve is plotted in Track 4 and is scaled from 0 to $1000 \mathrm{Ohm}-\mathrm{m}$. The warmer colors for the resistivity curve represent higher values and the colder colors represent the lower values. 


\section{Well 4704105144 \\ Lewis County, WV}

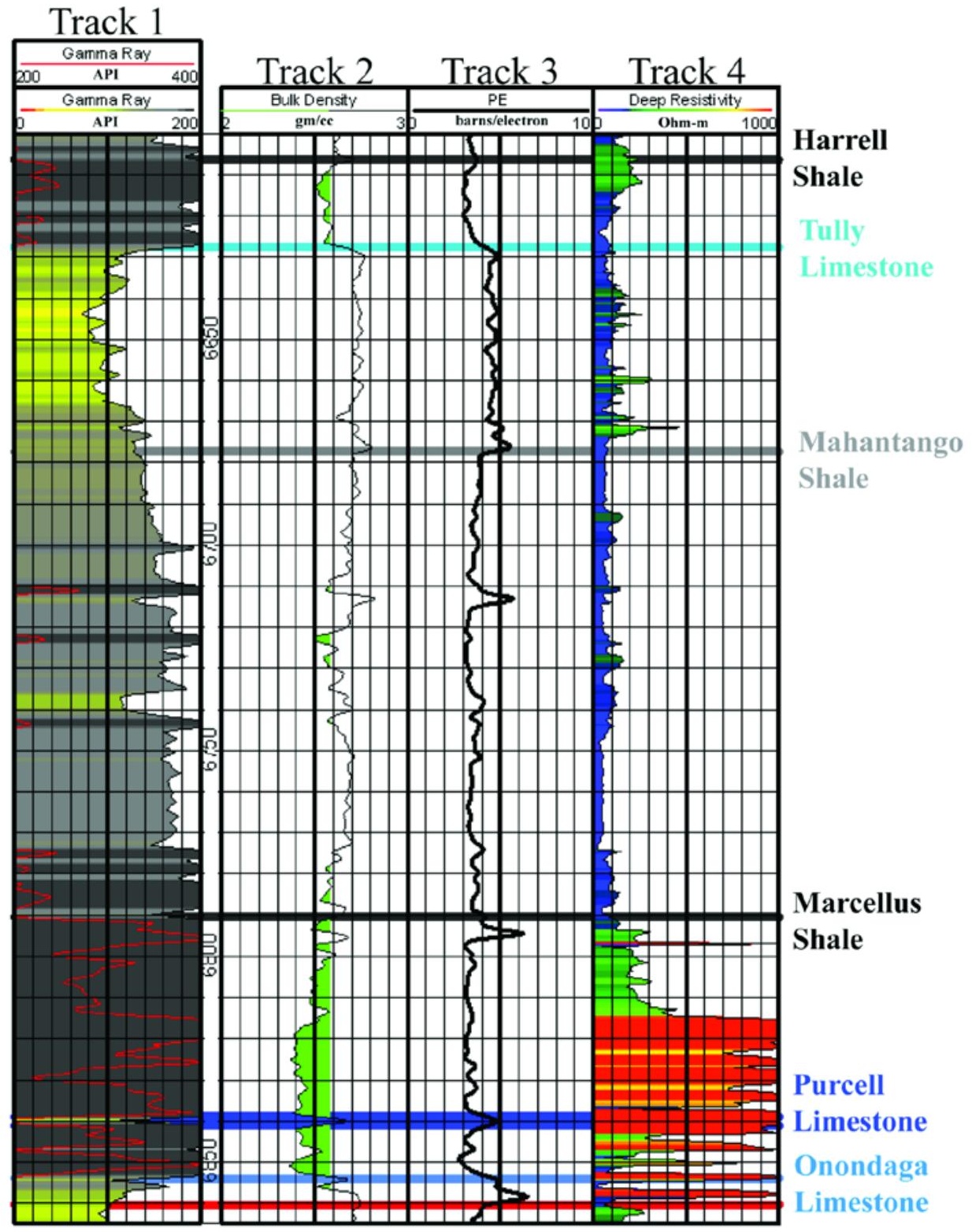

Figure 3-5. Type log for the entire interval for the study area in southwest Pennsylvania and West Virginia. The gamma ray curve is plotted in Track 1 and ranges from $0-200$ API. When the gamma ray exceeds 200 API, it wraps around and is outlined in red. The bulk density is plotted in Track 2 and is shaded green for bulk density values less than $2.55 \mathrm{~g} / \mathrm{cc}$. The photo electric (PE) curve is plotted on Track 3 and ranges from 0-10 barns/electron. The resistivity curve is plotted in Track 4 and is scaled from 0 to 1000 Ohm-m. The warmer colors for the resistivity curve represent higher values and the colder colors represent the lower values. 


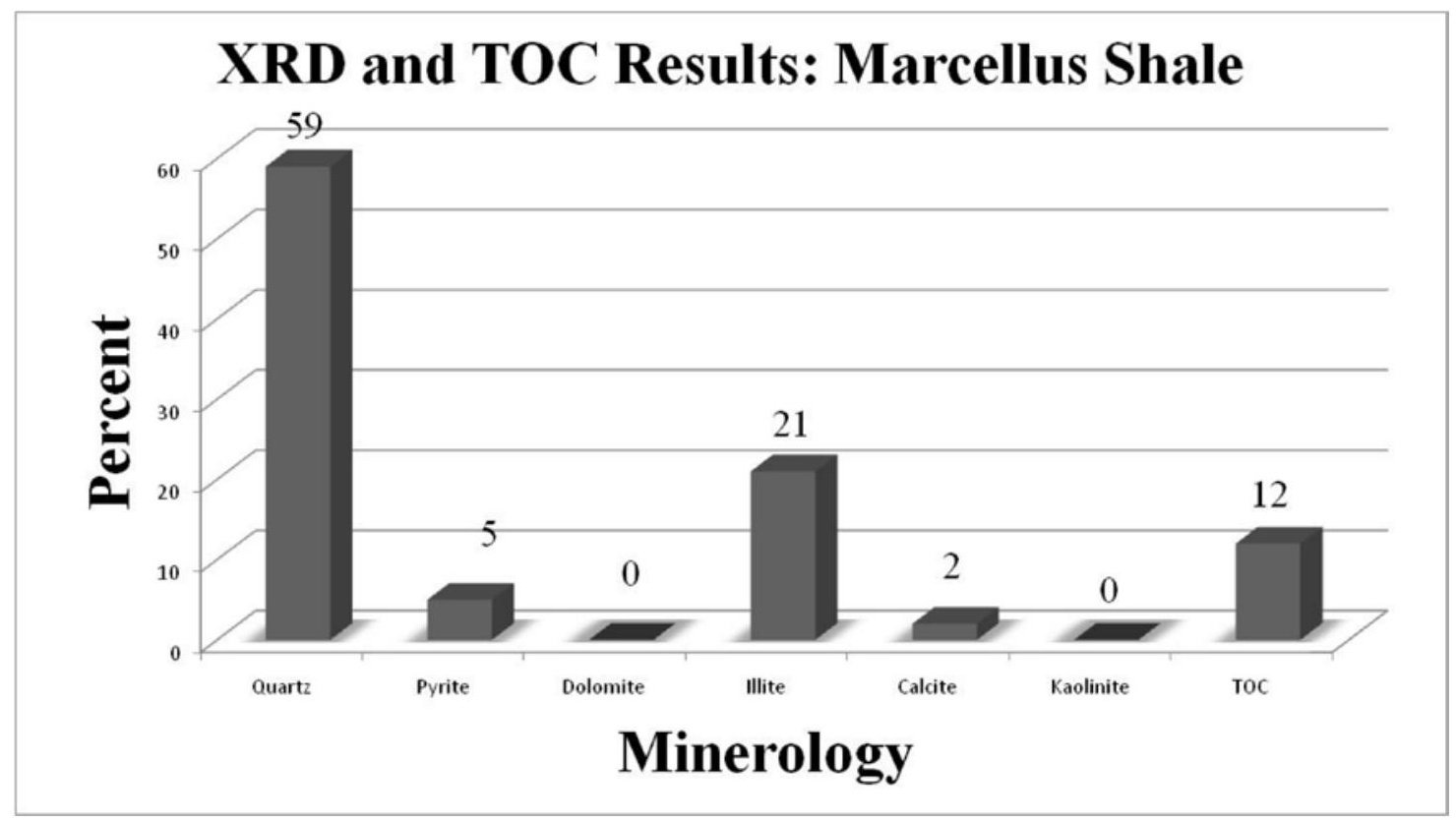

Figure 3-6. Example of typical X-ray diffraction (XRD) results for a single core sample of the Marcellus Shale in the study area. This sample has a high amount of quartz (59\%) and low amount of clay (21\%), which is characteristic of many of the core samples (Table 1). Also, there is a significant amount of pyrite and total organic carbon (TOC). The observed amount of pyrite ranges from $2-8 \%$ and the TOC ranges from $5-20 \%$. 


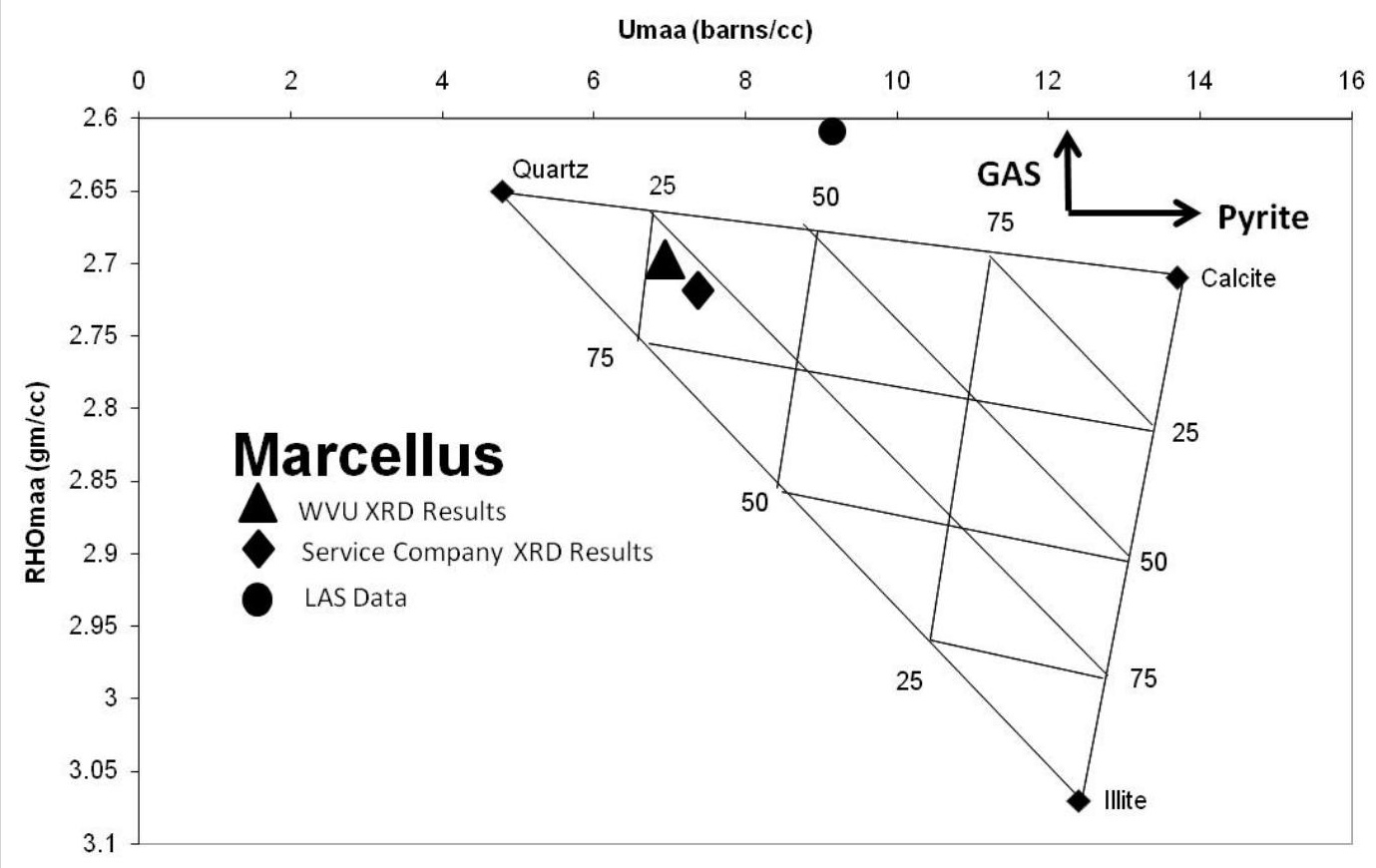

Figure 3-7. Example of a RHOmaa-Umaa plot compared with X-ray diffraction (XRD) results for a single core sample of the Marcellus Shale. XRD results for the same sample analyzed at both West Virginia University (triangle) and by a service company (diamond) are shown. The circle is the result of the RHOmaa-Umaa cross plot for the same interval represented by the core sample illustrating the effects of the pyrite in the rock (pulling the data to the right due to the higher number electrons associated with the iron in pyrite) and the gas or TOC pulling the data above the lithologic triangle (low RHOmaa value due to the low density of gas or TOC). The effect on these two components must be taken into consideration when identifying the lithology of the Marcellus as well as using the well logs to identify gas rich zones. 


\begin{tabular}{|c|c|c|c|c|c|c|c|c|c|}
\hline Well ID & $\begin{array}{c}\text { Depth } \\
\mathrm{ft}\end{array}$ & $\begin{array}{c}\text { Formation } \\
\text { Name }\end{array}$ & $\begin{array}{c}\text { Quartz } \\
\%\end{array}$ & $\begin{array}{c}\text { Pyrite } \\
\%\end{array}$ & \begin{tabular}{|c|} 
Dolomite \\
$\%$
\end{tabular} & $\begin{array}{c}\text { Illite } \\
\%\end{array}$ & $\begin{array}{c}\text { Calcite } \\
\%\end{array}$ & $\begin{array}{c}\text { Kaolinite } \\
\%\end{array}$ & $\begin{array}{c}\text { TOC } \% \\
\text { Tmax } 650 \\
\end{array}$ \\
\hline 3712927246 & 7017 & Harrell & 46 & 4 & 0 & 38 & 0 & 3 & 8 \\
\hline 3705924134 & 7277 & Harrell & 58 & 3 & 2 & 23 & 0 & 5 & 10 \\
\hline 4702105516 & 6143 & Tully & 1 & 0 & 0 & 0 & 97 & 0 & 3 \\
\hline 4702105516 & 6144 & Tully & 2 & 0 & 0 & 0 & 96 & 0 & 4 \\
\hline 4704105144 & 6750 & Mahantango & 44 & 4 & 0 & 36 & 6 & 4 & 6 \\
\hline 4704105144 & 6787 & Mahantango & 50 & 4 & 0 & 34 & 0 & 3 & 10 \\
\hline 3712927145 & 7314 & Mahantango & 36 & 5 & 0 & 42 & 0 & 6 & 9 \\
\hline 3700528666 & 7538 & Mahantango & 28 & 6 & 20 & 18 & 11 & 0 & 16 \\
\hline 4702105516 & 6182 & Marcellus & 60 & 4 & 0 & 11 & 4 & 0 & 20 \\
\hline 4702105516 & 6189 & Marcellus & 35 & 2 & 0 & 29 & 18 & 5 & 10 \\
\hline 4704105144 & 6812 & Marcellus & 38 & 4 & 0 & 35 & 13 & 2 & 7 \\
\hline 4704105144 & 6826 & Marcellus & 59 & 5 & 0 & 21 & 2 & 0 & 12 \\
\hline 3712927246 & 7392 & Marcellus & 54 & 4 & 0 & 28 & 0 & 3 & 11 \\
\hline 3712927246 & 7403 & Marcellus & 50 & 3 & 0 & 40 & 0 & 2 & 5 \\
\hline 3712927145 & 7411 & Marcellus & 44 & 8 & 0 & 31 & 6 & 0 & 11 \\
\hline 3712927145 & 7425 & Marcellus & 48 & 4 & 0 & 10 & 24 & 0 & 12 \\
\hline 3712927246 & 7487 & Marcellus & 51 & 5 & 4 & 20 & 5 & 0 & 16 \\
\hline 3712927246 & 7503 & Marcellus & 38 & 6 & 0 & 36 & 12 & 0 & 8 \\
\hline 3705924134 & 7513 & Marcellus & 35 & 2 & 5 & 31 & 12 & 5 & 9 \\
\hline 3712927246 & 7522 & Marcellus & 56 & 3 & 3 & 16 & 13 & 0 & 10 \\
\hline 3705924134 & 7553 & Marcellus & 42 & 4 & 3 & 41 & 0 & 3 & 7 \\
\hline 3700528666 & 7583 & Marcellus & 44 & 4 & 5 & 28 & 5 & 2 & 12 \\
\hline 3705924134 & 7594 & Marcellus & 38 & 4 & 3 & 41 & 0 & 3 & 8 \\
\hline 3705924134 & 7607 & Marcellus & 46 & 4 & 4 & 34 & 0 & 0 & 13 \\
\hline 3700528666 & 7619 & Marcellus & 58 & 2 & 5 & 9 & 15 & 0 & 11 \\
\hline 3705924134 & 7622 & Marcellus & 51 & 6 & 3 & 25 & 0 & 0 & 16 \\
\hline 4700102850 & 7626 & Marcellus & 38 & 6 & 3 & 40 & 0 & 2 & 12 \\
\hline 4700102850 & 7639 & Marcellus & 53 & 6 & 4 & 24 & 3 & 0 & 10 \\
\hline 4700102850 & 7657 & Marcellus & 47 & 6 & 4 & 27 & 3 & 0 & 11 \\
\hline 4700102850 & 7670 & Marcellus & 45 & 5 & 2 & 25 & 5 & 0 & 16 \\
\hline 4700102850 & 7704 & Marcellus & 54 & 3 & 4 & 17 & 9 & 0 & 11 \\
\hline 3712927145 & 7426 & $\begin{array}{c}\text { Marcellus- } \\
\text { Onondaga } \\
\text { Contact } \\
\end{array}$ & 44 & 0 & 0 & 0 & 51 & 0 & 4 \\
\hline 4700102850 & 7705 & $\begin{array}{c}\text { Marcellus- } \\
\text { Onondaga } \\
\text { Contact } \\
\end{array}$ & 36 & 2 & 2 & 7 & 44 & 0 & 8 \\
\hline
\end{tabular}

Table 3-2. Table listing the 36 samples of Middle Devonian units analyzed for mineralogy using X-ray diffraction (XRD) and pyrolysis for total organic carbon (TOC).

\begin{tabular}{|c|c|c|c|c|c|c|c|}
\hline Marcellus & Quartz \% & Pyrite \% & Dolomite \% & Illite \% & Calcite \% & Kaolinite \% & TOC \% \\
\hline Mean & 47 & 4 & 2 & 27 & 6 & 1 & 11 \\
\hline Max & 60 & 8 & 5 & 41 & 24 & 5 & 20 \\
\hline Min & 35 & 2 & 0 & 9 & 0 & 0 & 5 \\
\hline
\end{tabular}

Table 3-3. Table summarizing the mean, maximum and minimum values in the Marcellus Shale for 23 samples analyzed for mineralogy using X-ray diffraction (XRD) and pyrolysis for total organic carbon (TOC). 


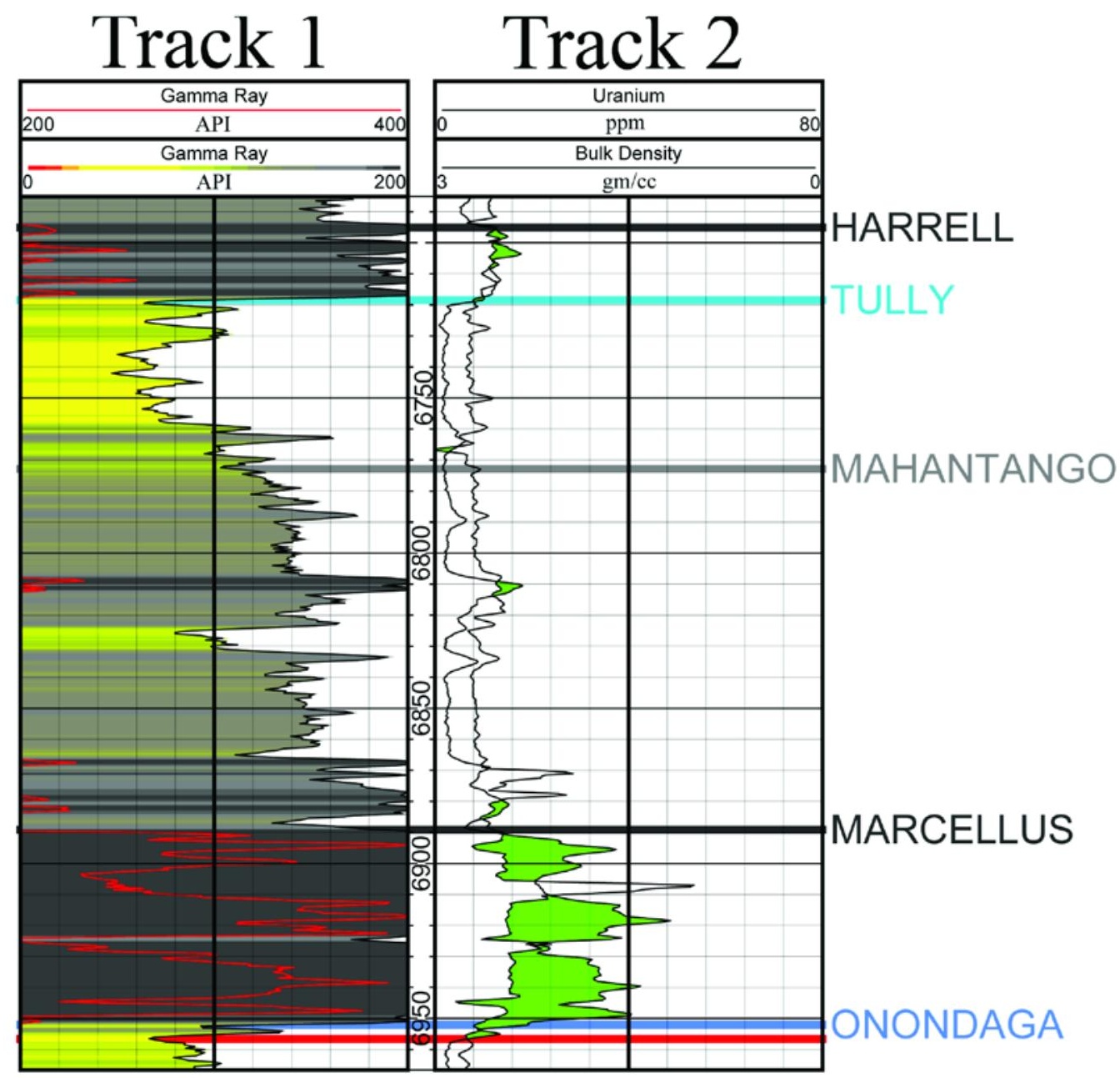

Figure 3-8. Uranium (U) concentration (ppm) from the spectral gamma ray log and density porosity is plotted on a consistent scale (Track 2) to highlight (cross-over) potential gas rich intervals. Zones where the U-content plots above the bulk density value are highlighted and interpreted as high potential gas rich intervals. In addition to the identification of gas-rich intervals in the Marcellus Shale, thin gas-rich intervals are indicated in the Mahantango and Harrell shale units. 


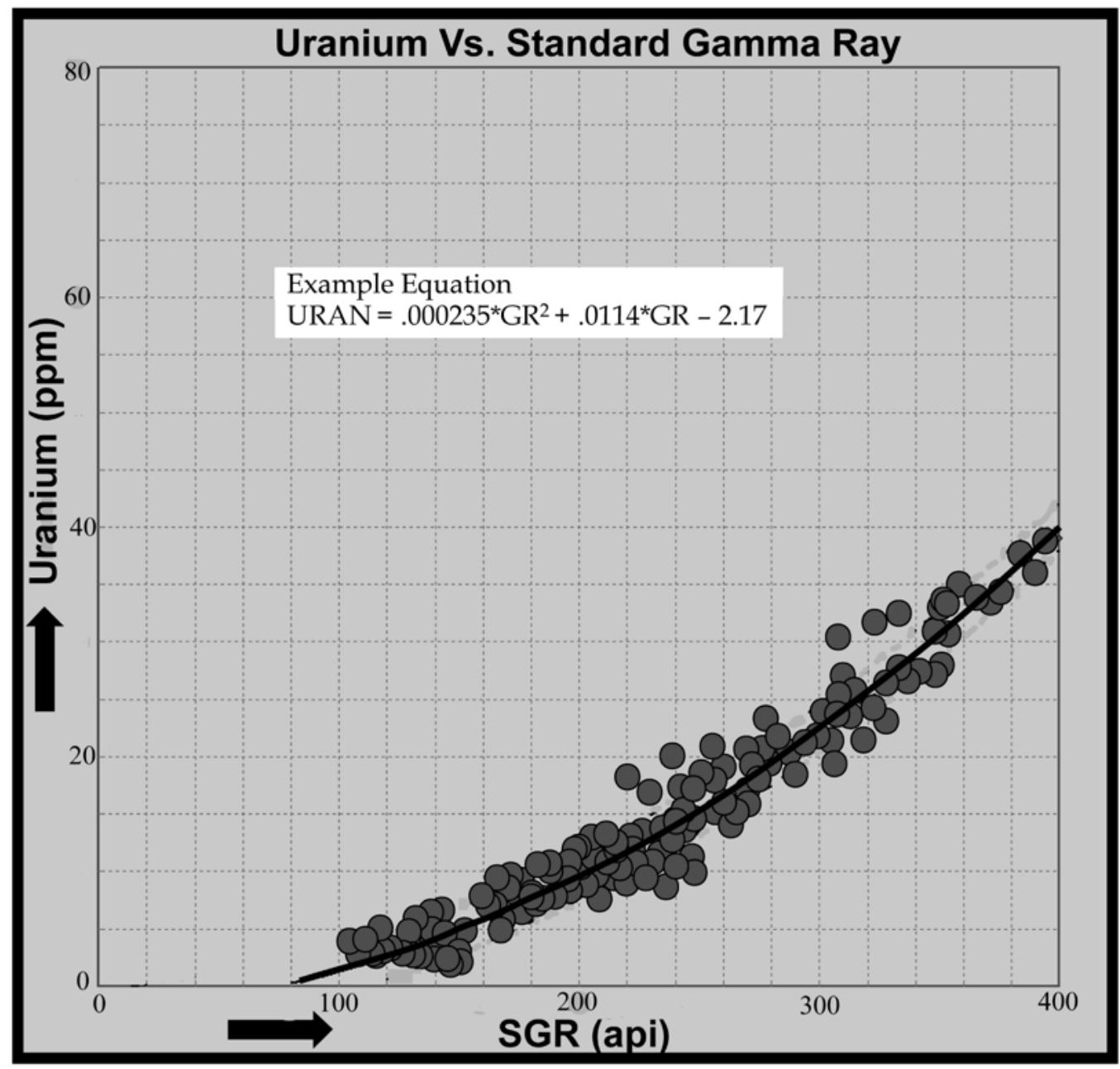

Figure 3-9. Plot of the uranium (U) concentration (ppm) derived from the spectral gamma ray log against the standard gamma ray (SGR in API units). An increase in U concentration can be predicted by an increase in the SGR using a polynomial equation. $U$ concentration can be calculated and extrapolated spatially from the limited spectral logs using the abundant SGR logs. 


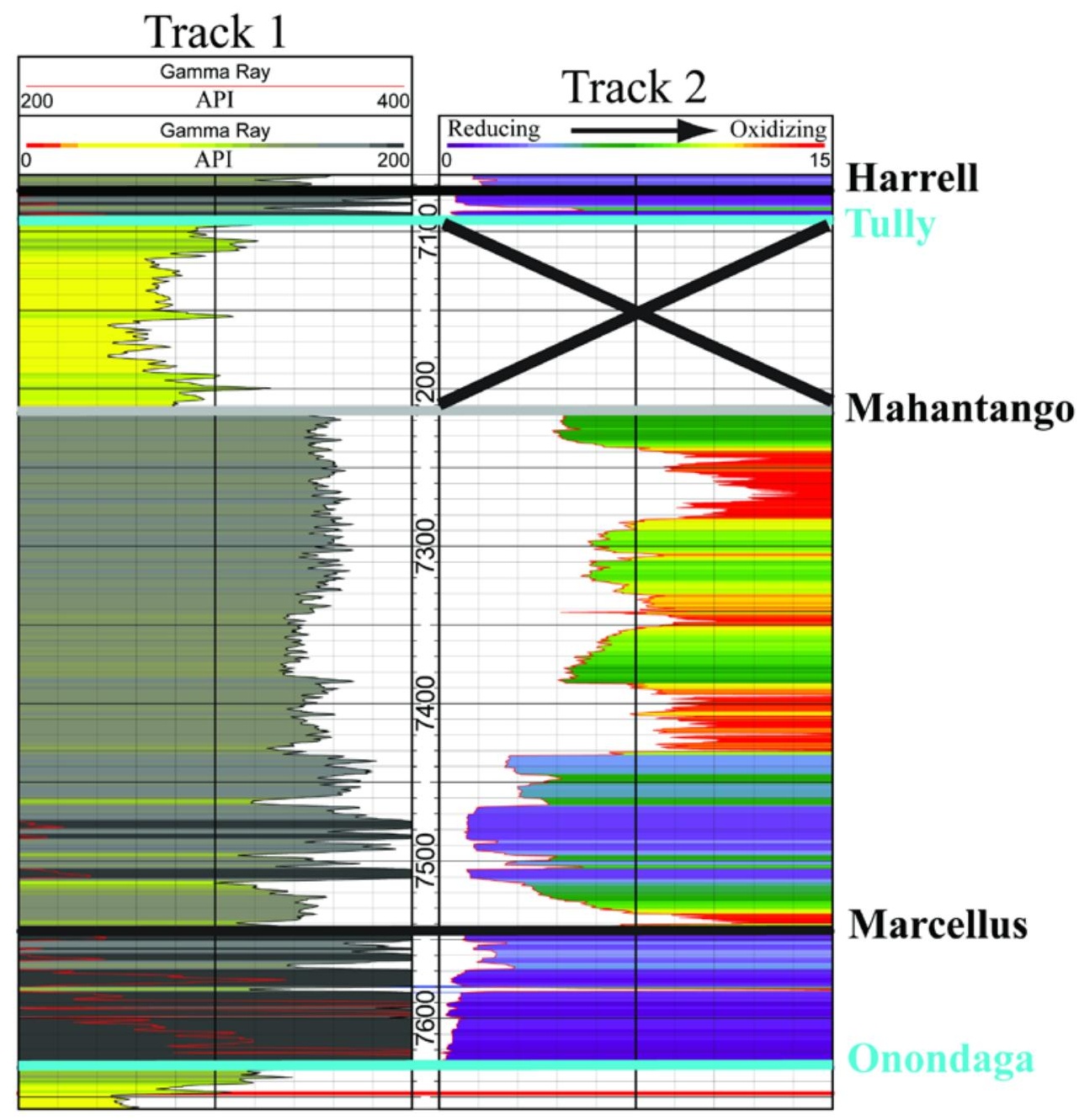

Figure 3-10. Log plot of thorium-uranium ratio illustrating interpreted changes in oxidizing and reducing conditions during the time of deposition. The curve (Track 2) represents oxidizing conditions to the right (represented by warmer colors) and reducing conditions to the left. Note the reducing conditions in the Marcellus Shale and the cyclic reducing/oxidizing conditions (oxic/anoxic) in the Mahantango Shale. Cyclicity suggests rapid changes in geochemical conditions and that the bottom waters and sediments may not have been synchronously anoxic. 


\subsection{MIDDLE DEVONIAN DEPOSITIONAL PATTERNS}

During the Middle Devonian, the central Appalachian basin was a shallow foreland basin located at the margin of the North American craton. In general, the basin geometry would have been a gentle ramp decreasing to the southwest and would have had little circulation because of the position of the landmasses at the time.

\subsection{Onondaga Limestone}

The Onondaga Limestone is a fine-grained limestone that has a wide distribution across the study area (Figure 3-11). Previous studies of the Onondaga have focused on its description and deposition close to its type section in New York. In New York, it is commonly described as a calcarenitic, cherty or argillaceous limestone with numerous deepening upwards successions (Brett and Ver Straeten, 1994). In the study area, the Onondaga decreases in depositional complexity and previous studies have suggested that regionally it is a gradational member of the Needmore Shale to the east (Hasson and Dennison, 1988). In outcrop, the Needmore was divided into three informal members in ascending order: lower Beaverdam shale, middle calcareous shale, and upper calcareous shale and limestone. In eastern West Virginia, the upper calcareous shale and limestone is formally recognized as the Selinsgrove Limestone (Hasson and Dennison, 1988). This suggests that below the Marcellus is an angular unconformity with the Onondaga (Selinsgrove Limestone), Huntersville Chert, or older strata (Hasson and Dennison, 1988). It has been suggested that the lower contact of the Onondaga is unconformable with the Huntersville or older strata (Boyce and Carr, 2009). In this study, the lower contact of the Onondaga was identified to produce an isopach map (Figure 3-11), but identification of the stratigraphic unit underlying the Onondaga was not completed. 
The Onondaga Limestone was deposited across the entire study area with two distinct areas of thicker accumulation separated by a trough were the Onondaga thins to less than one foot $(30 \mathrm{~cm})$ and may be completely absent (Figure 11). The areas of rapidly thickening Onondaga Limestone correspond to areas that relate to regional paleofeatures that persisted throughout the Middle Devonian. In the west (Trend A, Figure 11), the thick Onondaga accumulated on a structural inversion during the Acadian orogeny along the southern West Virginia segment of the west limb of the Rome trough (Gao and others, 2000; Wilson, 2000). This positive feature in southern West Virginia which has been labeled the Warfield structure is defined with gravity anomalies, the $38^{\text {th }}$ parallel, Burning Mann lineaments, and an East-Margin fault as mapped with seismic and subsurface data (Gao and Schumaker, 1996). The Onondaga Limestone increases to over 30 feet $(9 \mathrm{~m})$ on the west limb of the Rome trough, which is interpreted as a positive paleo-topographic feature that enhanced, carbonate production and accumulation.

In the eastern part of the study area, the Onondaga Limestone rapidly thickens across a north-northwest trend (Figure 11, Trend B). This area of rapid change in stratigraphic thickness persisted and affected the deposition of all Middle Devonian intervals. This feature is interpreted as defining the edge of a paleo-topographical positive feature to the east and northeast where the Onondaga Limestone accumulation is similar in thickness, as observed on the west limb of the Rome trough (30ft, 10m) (Figure 11, Trend B). The similar thickness of observed Onondaga may be an indication of the amount of accommodation space available on these positive shelf-like features.

In the region to the northeast of thicker Onondaga deposits, a thin black shale unit exists in the subsurface at the base of the Onondaga (Figure 3-11, 3-12, 3-13). This 
calcareous black shale unit appears to be equivalent to what is described in the outcrop of the same section in western Maryland as the middle calcareous or upper calcareous shale member of the Needmore Shale (Anderson and others, 1984; Swezey, 2002). Further surface stratigraphic investigation would need to verify that this shale is not a member of the Onondaga and a separate formation, but for the purposes of this investigation the unit will be recognized as the Needmore Shale. The Needmore, as mapped, thickens to the east and suggests that early in Onondaga deposition, fine-grained siliciclastic sediment was input into the system from an eastern source.

Also across the positive feature in the northeast, rapid changes in thickness (delta $>10 \mathrm{~m}$ ) of the Onondaga Limestone were observed in relatively small, localized areas (10$20 \mathrm{~km}$ ) (Figure 3-11, 3-13). These areas are interpreted as localized paleotopographic highs and lows affecting accumulation of the Onondaga Limestone and the result of local structures that were active during the Middle Devonian. These structures could be tied to small basins formed by salt removal and movement of evaporates in the underlying Upper Silurian Salina Formation or as a result of deformation related to early periods of the Acadian Orogeny. Similar scale salt removal basins and structures have been recognized in the Finger Lakes region of New York (Chute, 1972) and in the Appalachians (e.g. Harrison et al. 2004). 


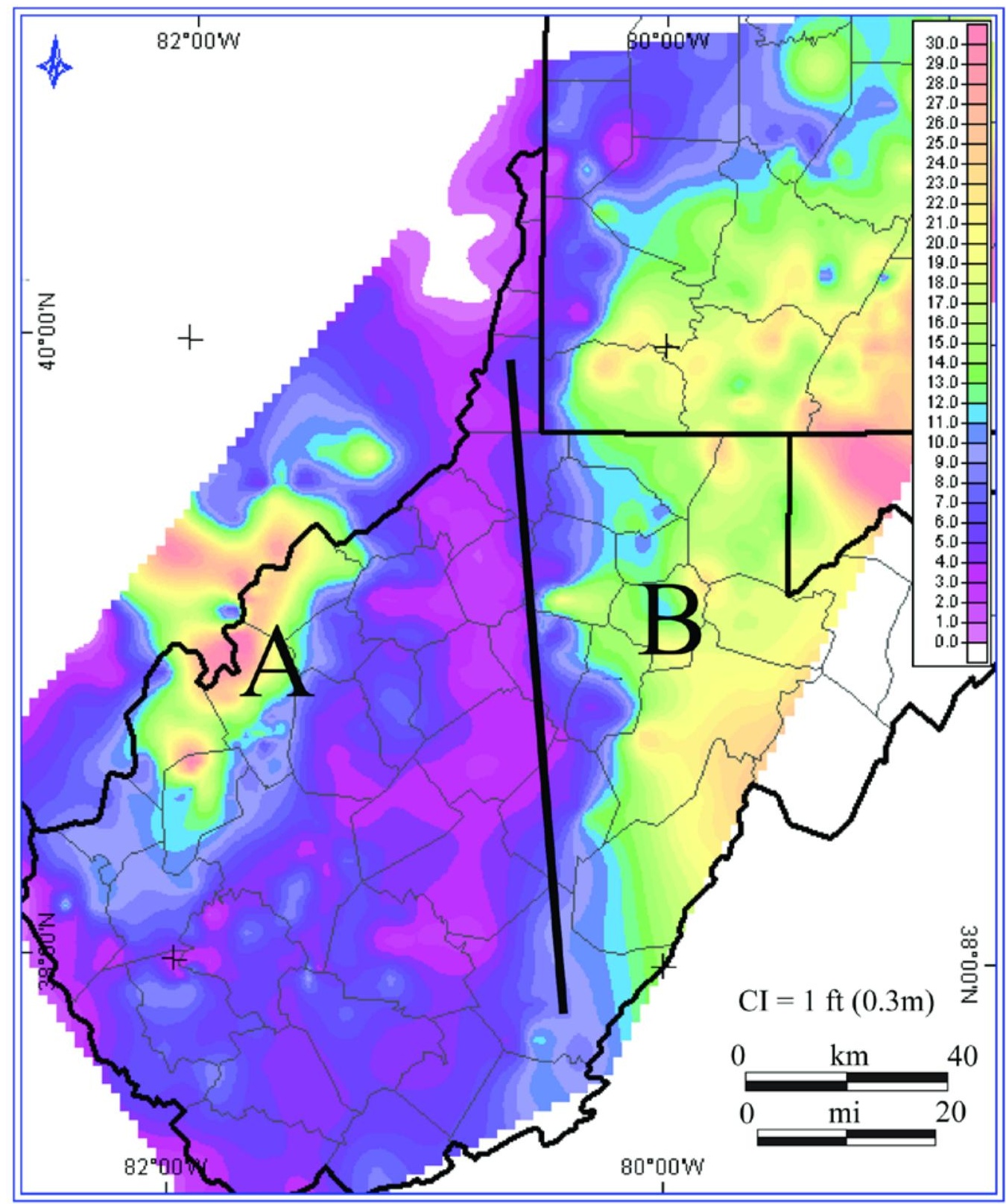

Figure 3-11. Isopach of the Onondaga Limestone showing an overall decrease in thickness from the northeast (30 feet, $9 \mathrm{~m}$ ) to southwest ( $<1 \mathrm{foot}, 0.5 \mathrm{~m})$. Contour interval (CI) is $1 \mathrm{ft}(0.3 \mathrm{~m})$. The rapid decrease in thickness is concentrated along a northwest to southeast trend (B). This feature is interpreted as the edge of a shelf-like topographic high to the northeast which enhanced limestone accumulation. The slope break feature along (B) persists and affects the deposition of overlying Middle Devonian units. The anomalous thick to the southwest (A) is associated with the Warfield structure which resulted from structural inversion of the west bounding limb of the Rome trough suggesting that the feature was active during Onondaga deposition. 


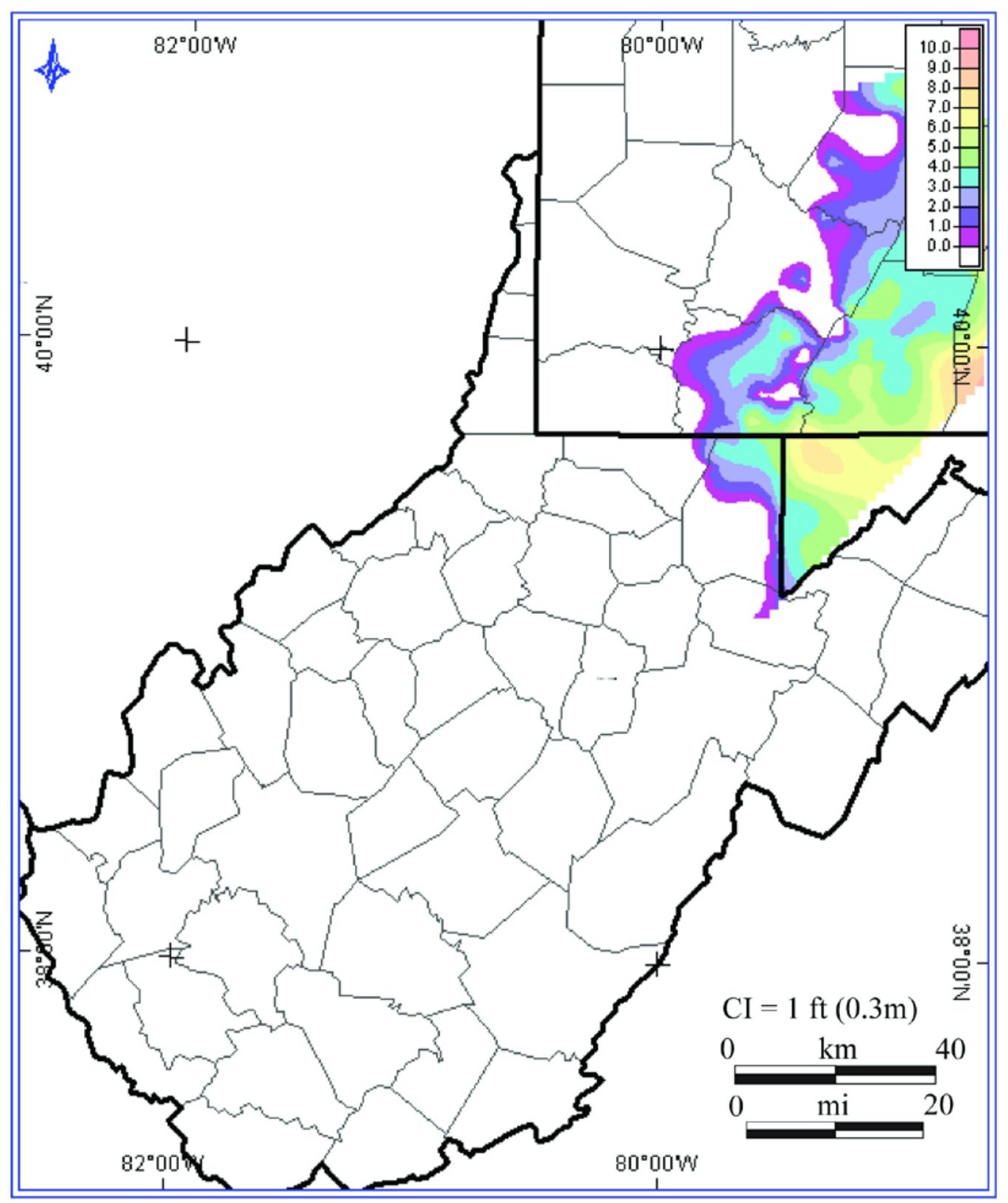

Figure 3-12. Isopach map of the black shale observed at the base of the Onondaga Limestone and is interpreted as part of the Needmore Shale that outcrops in western Maryland. Contour interval (CI) is $1 \mathrm{ft}(0.3 \mathrm{~m})$. The Needmore Shale thickens to the east suggesting that early in Onondaga deposition there was a siliciclastic source to the east. 


\section{Mahantango Deposition}

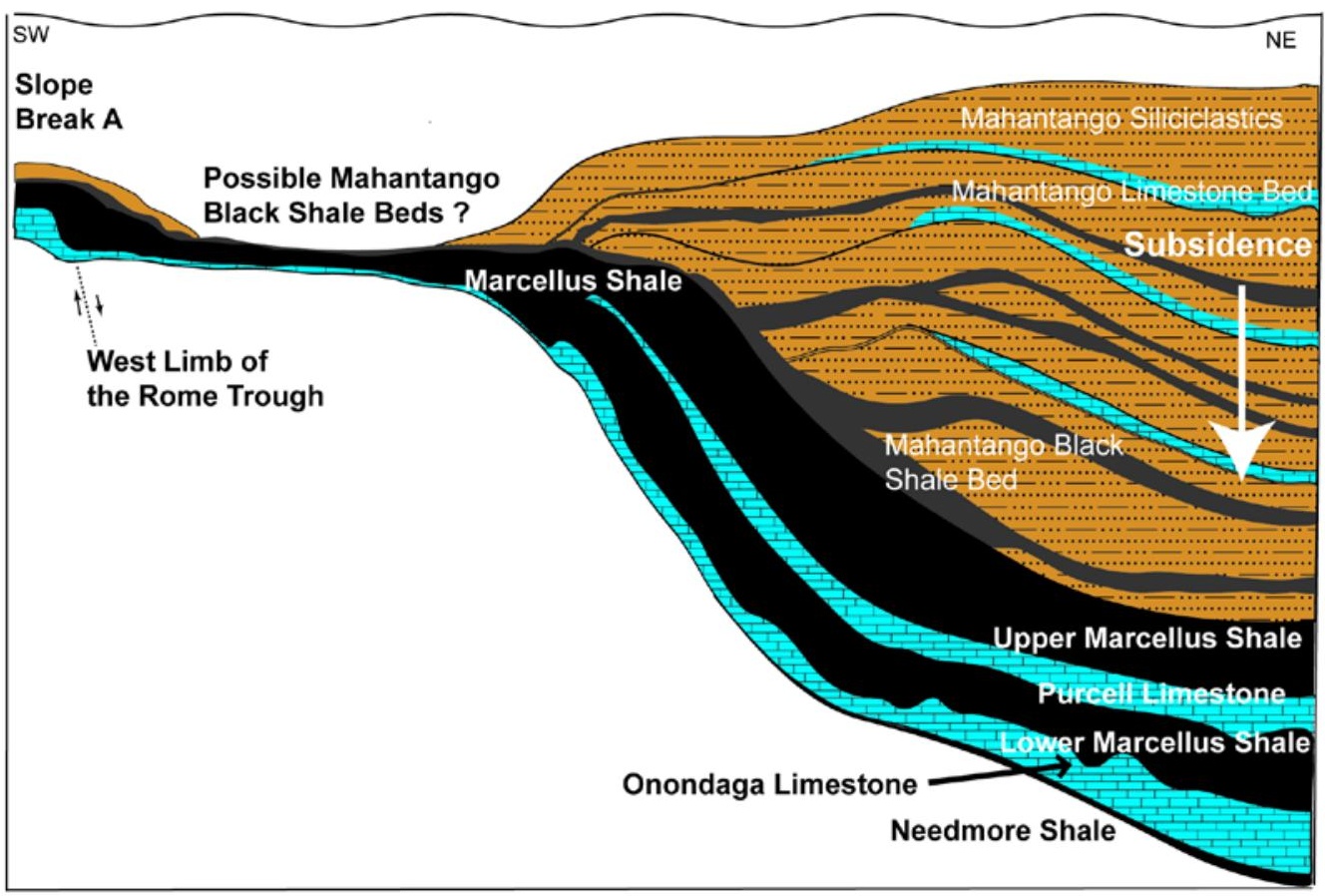

\section{Marcellus and Purcell Deposition}

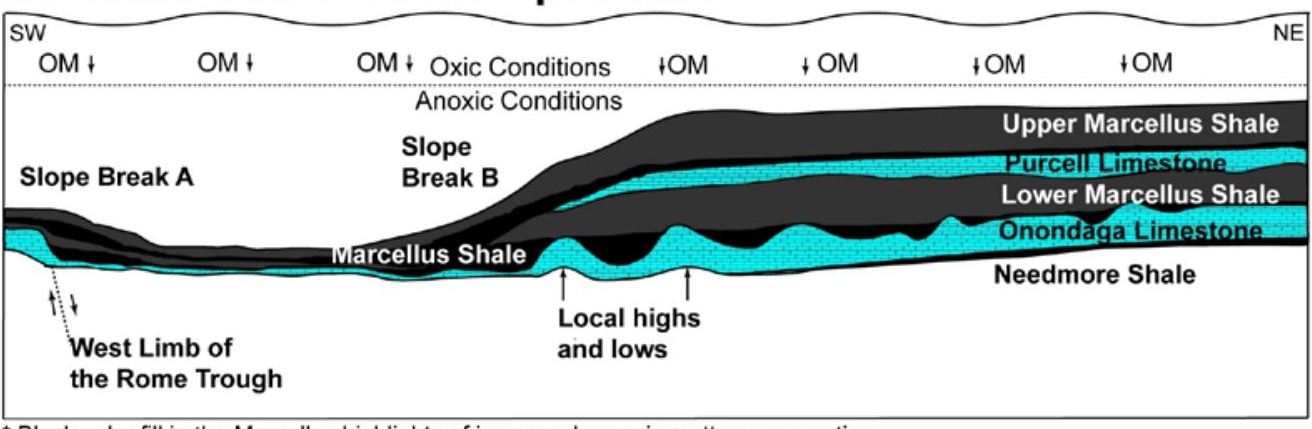

* Black color fill in the Marcellus highlights of increased organic matter preservation

\section{Onondaga Deposition}

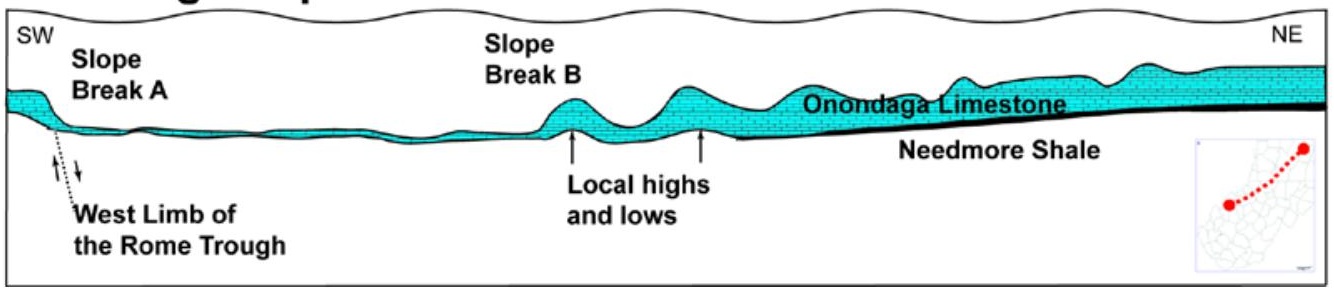

Figure 3-13. Conceptual cross-sectional depositional model for the lower four Middle Devonian units in the central Appalachian basin. Model cross-section runs from southwest Pennsylvania to western West Virginia and highlights the intepreted slope breaks at A and B that influence the deposition during the Middle Devonian. Shale units in the cross-section model for Marcellus and Purcell deposition are shaded with black in the areas that are interpreted to have increased accumulation of organic matter. 


\subsection{Marcellus Shale}

Immediately overlying the Onondaga Limestone is the black organic-rich Marcellus Shale. The depositional change from fine-grained limestone to black shale can be observed in core and is represented on logs as a gradational contact. While there is a distinct change from limestone to black shale as the dominant facies, occasional discontinuous limestone beds exist throughout the Marcellus. The sporadic limestone beds suggest that the bottom waters and sediments of Devonian shale units were not synchronously anoxic (Schrieber, 1994, 1998).

In general, the Marcellus Shale shows an overall decrease in thickness from the northeast (170 feet, $51.8 \mathrm{~m}$ ) to southwest ( $<5$ feet, $1.5 \mathrm{~m}$ ) across the study area. The regional features present in the underlying Onondaga also influenced the deposition of the Marcellus (Trends A and B, Figure 3-14). An area along the downthrown edge of Warfield structure (A) shows an increase in thickness in the Marcellus Shale that could have created a regional slope break environment enhancing organic production and potential accumulation (Figure 3-13, 3-14, 3-15). In a similar fashion, a sharp change in Marcellus Shale thickness correlates to the same northwest to southeast paleotopographic feature interpreted in the underlying Onondaga Limestone (B). Both regional trends could have created slope break environments enhancing organic production and potential accumulation (Figure 3-13, 3-14, 3-15). Using the polynomial relationship for measured uranium (ppm) and the standard full-spectrum gamma ray (API), a net uranium map was created for the Marcellus at $15 \mathrm{ppm}$ to highlight potential areas with higher TOC (Figure 3-15). This map highlights a distinct north-south trend of higher uranium 
concentration and infers higher TOC content that is offset from the thick isopach trends in the Marcellus net shale isopach (Figures 3-14 and 3-15, Trend B).

In addition to thin discontinuous limestone beds, the Purcell Limestone Member, where present, informally separates the Marcellus into an upper and lower unit. The Purcell is widespread to the east of the slope break, as defined at trend $\mathrm{B}$, and the inferred higher TOC content in the Marcellus Shale (Figures 3-13, 3-15, and 3-16). 


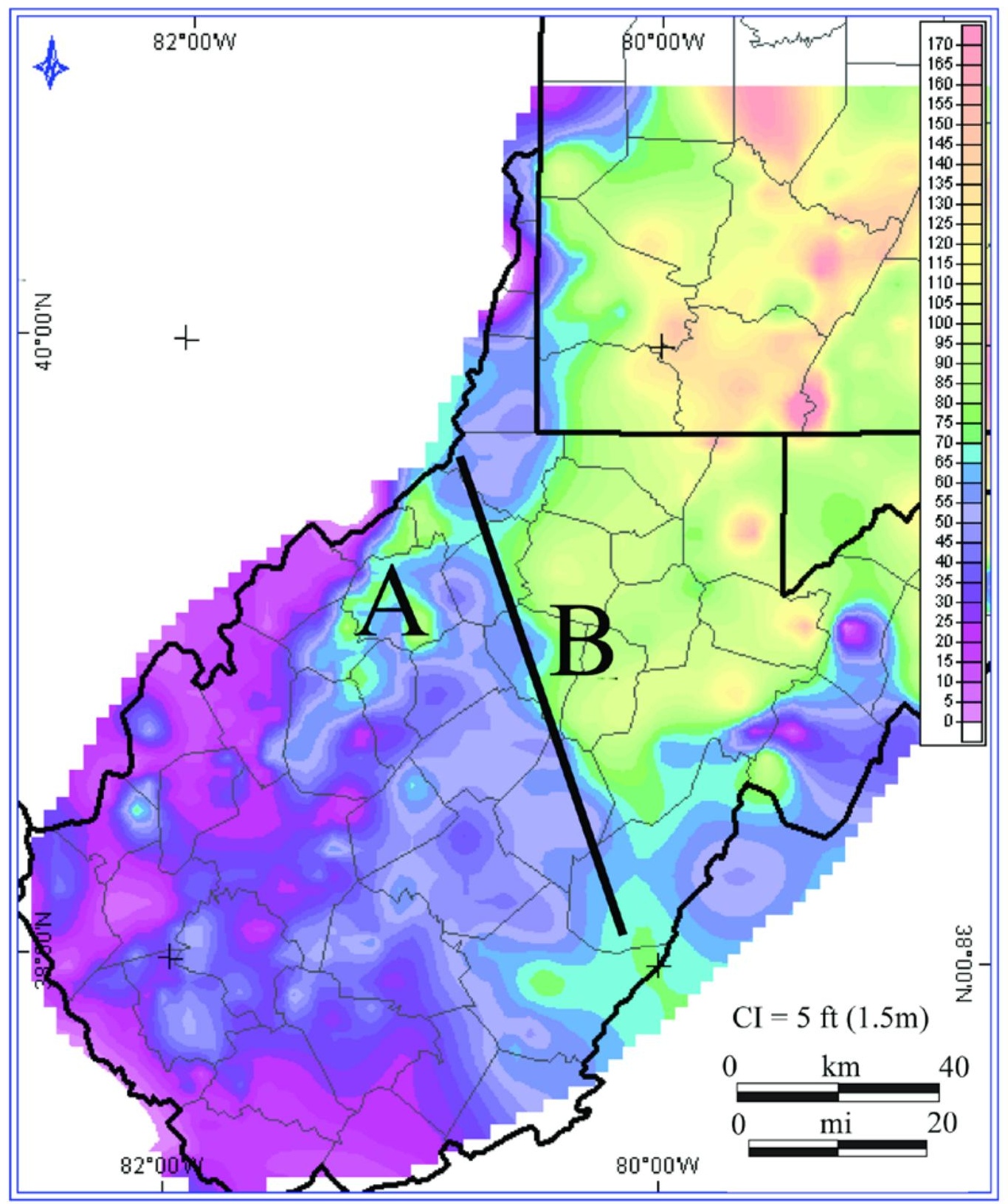

Figure 3-14. Net shale isopach of the Marcellus Shale showing an overall decrease in thickness from the northeast (170 feet, $51.8 \mathrm{~m}$ ) to southwest ( $<5$ feet, $1.5 \mathrm{~m}$ ). Contour interval (CI) is $5 \mathrm{ft}(1.5 \mathrm{~m})$. Rapid decrease in thickness is concentrated along the northwest to southeast trend (B), which was first observed in the underlying Onondaga Limestone. This feature is interpreted as a slope break that enhanced production and accumulation of organic-rich mud during Marcellus deposition. An anomalous thick to the southwest (A) is associated with the west bounding limb of the Rome Trough structure. Trend A suggests that the inverted structure of the Rome trough remained a positive topographic feature during Marcellus deposition. 


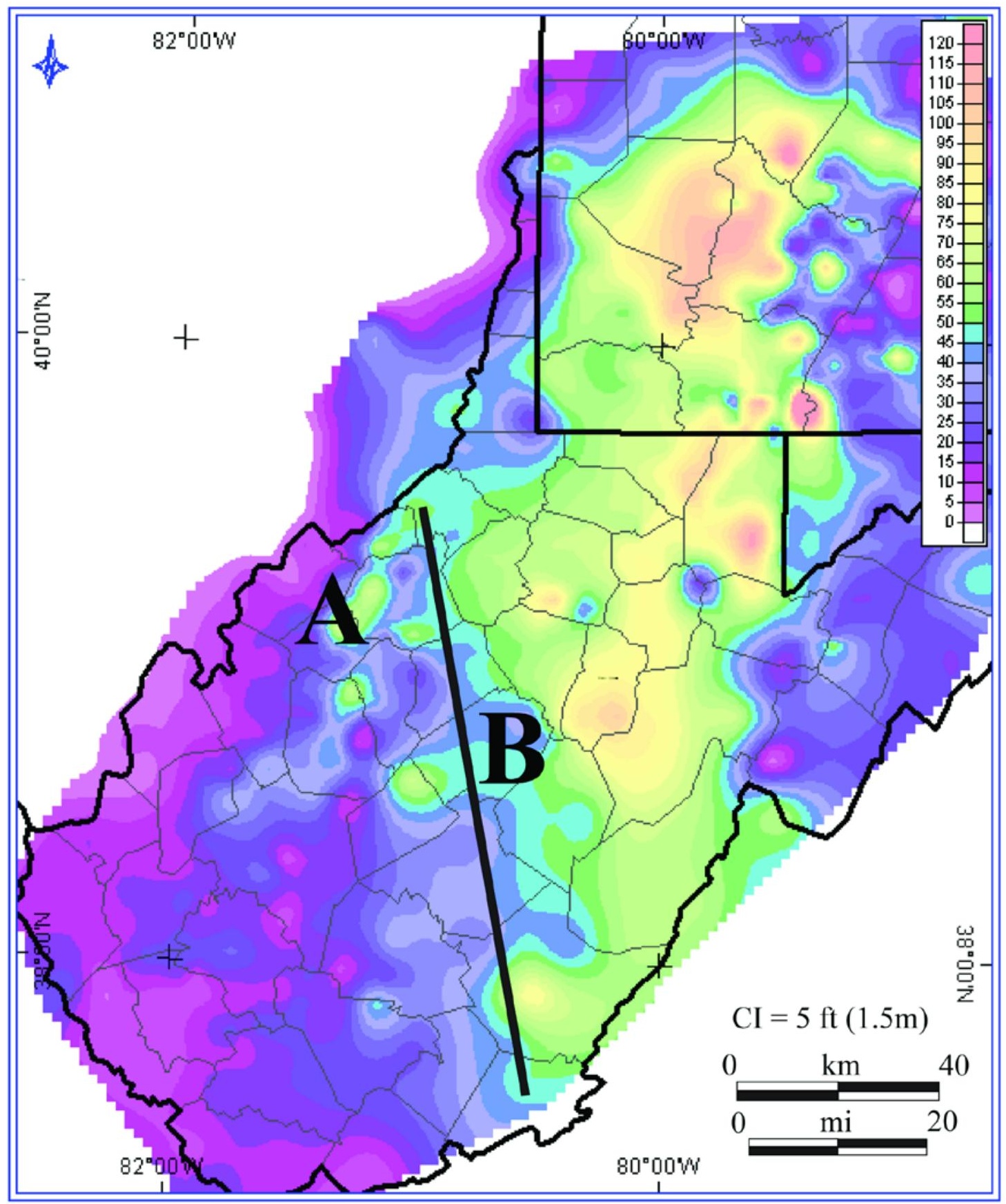

Figure 3-15. Interpreted organic richness illustrated by a net uranium map of the Marcellus at $15 \mathrm{ppm}$. Contour interval is $5 \mathrm{ft}(1.5 \mathrm{~m})$. The trends in rapid change in thickness (A \& B) highlight areas favorable for enhanced organic production and accumulation. These trends are interpreted to be related to shelf breaks formed as a result of the uplifted limb of the Rome trough and to shelf-like area in eastern West Virginia and western Pennsylvania that affected deposition of all Middle Devonian units. 


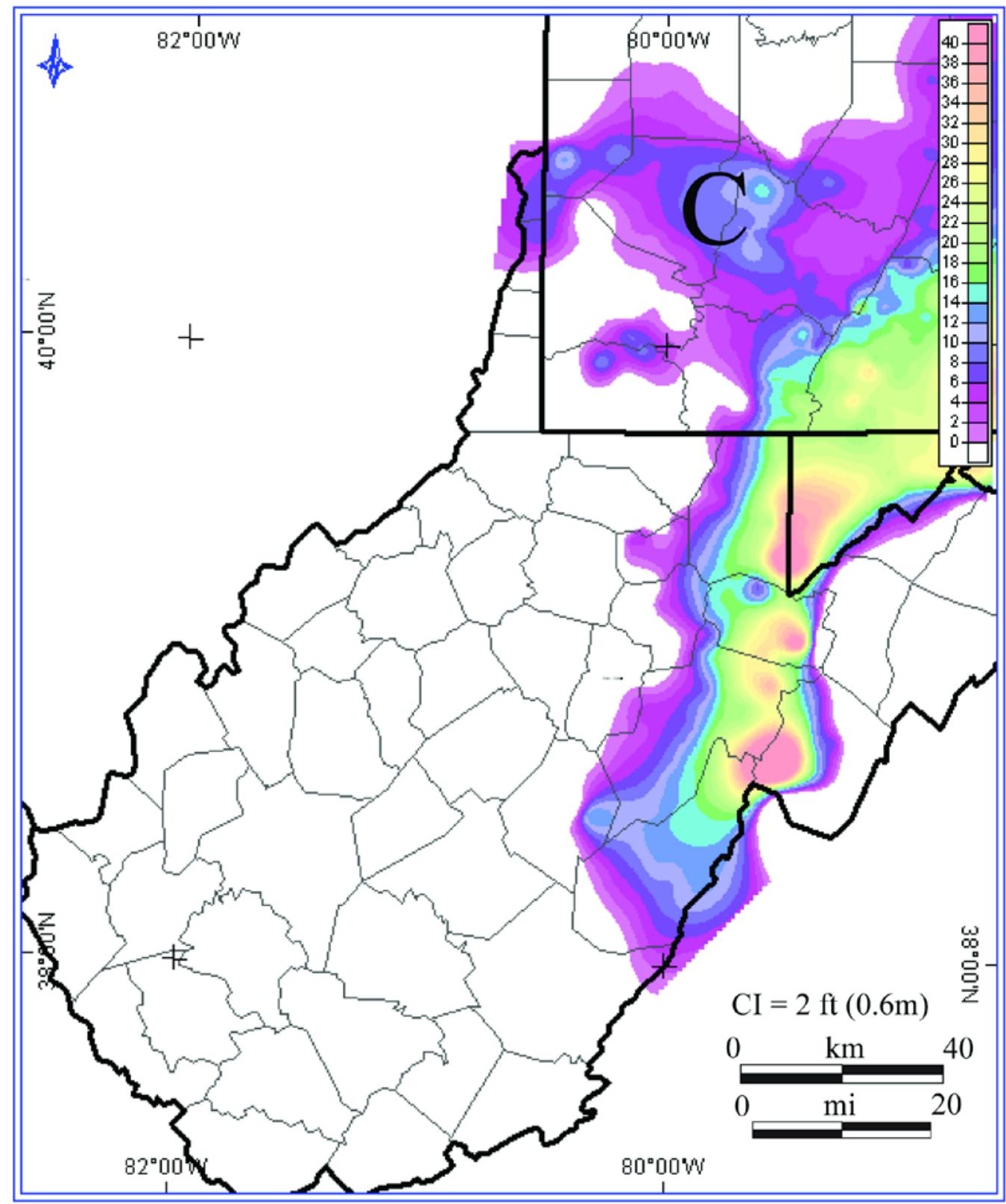

Figure 3-16. Isopach of the Purcell Limestone Member of the Marcellus Shale showing a northeast to southwest trend. Contour interval is $2 \mathrm{ft}(0.6 \mathrm{~m})$. The Purcell thickens to over 40 feet $(12.2 \mathrm{~m})$ but was not identified in the west or central regions of the study area, with the exception of an east-west oriented trend (C). The Purcell is interpreted to have been deposited in areas that were topographically higher during Marcellus deposition where clastic sediment supply and organic production were inhibited allowing for limestone deposition. 


\subsection{Mahantango Shale}

Immediately above the Marcellus is the more siliciclastic-rich Mahantango Shale. In relation to basin deposition and tectonics, the Mahantango represents the first pulse in the study area of coarser sediment associated with the Catskill delta and Acadian Orogeny (Faill, 1985; Duke and Prave, 1996). The Mahantango is a complex unit with multiple lithologies including intervals of carbonate, coarse siliciclastic and organic-rich shale. It has been described as a prograding clastic wedge with fluvial and storm dominated deposits (Prave and Duke, 1996). As mapped across the study area, the Mahantango Shale shows a rapid decrease in thickness from the interpreted sediment source thinning northeast to southwest (Figure 3-17). The Mahantango terminates to the southwest along the feature first defined in the Onondaga Limestone. The Mahantango was not present in numerous wells across central West Virginia (Figure 3-13, 3-17).

Occasional organic-rich black shale beds were observed in the Mahantango to the northeast and southwest and are interpreted to represent periods when the coarser sediment supply decreased and permitted accumulation of undiluted organic-rich shale (Figures 3-13, 3-17). Black shale beds in the Mahantango decrease in frequency to the northeast as the delta complex prograded further to the southwest. Occurring with some frequency in the Mahantango are limestone units and beds that are only present to the northeast on the shelf-like feature defined by the Onondaga. The carbonate units are interpreted as the tops of the prograding clinoforms and are absent to the southwest in the deeper basin (Figure 3-13). There is a small area of Mahantango Shale to the southwest of trend B (Figure 3-13 and 3-17). The presence of this outlier of relatively thin 
Mahantango Shale in western West Virginia suggests the possibility of another sediment source to the west or north rather than the northeast (possibly the Cincinnati arch?). 


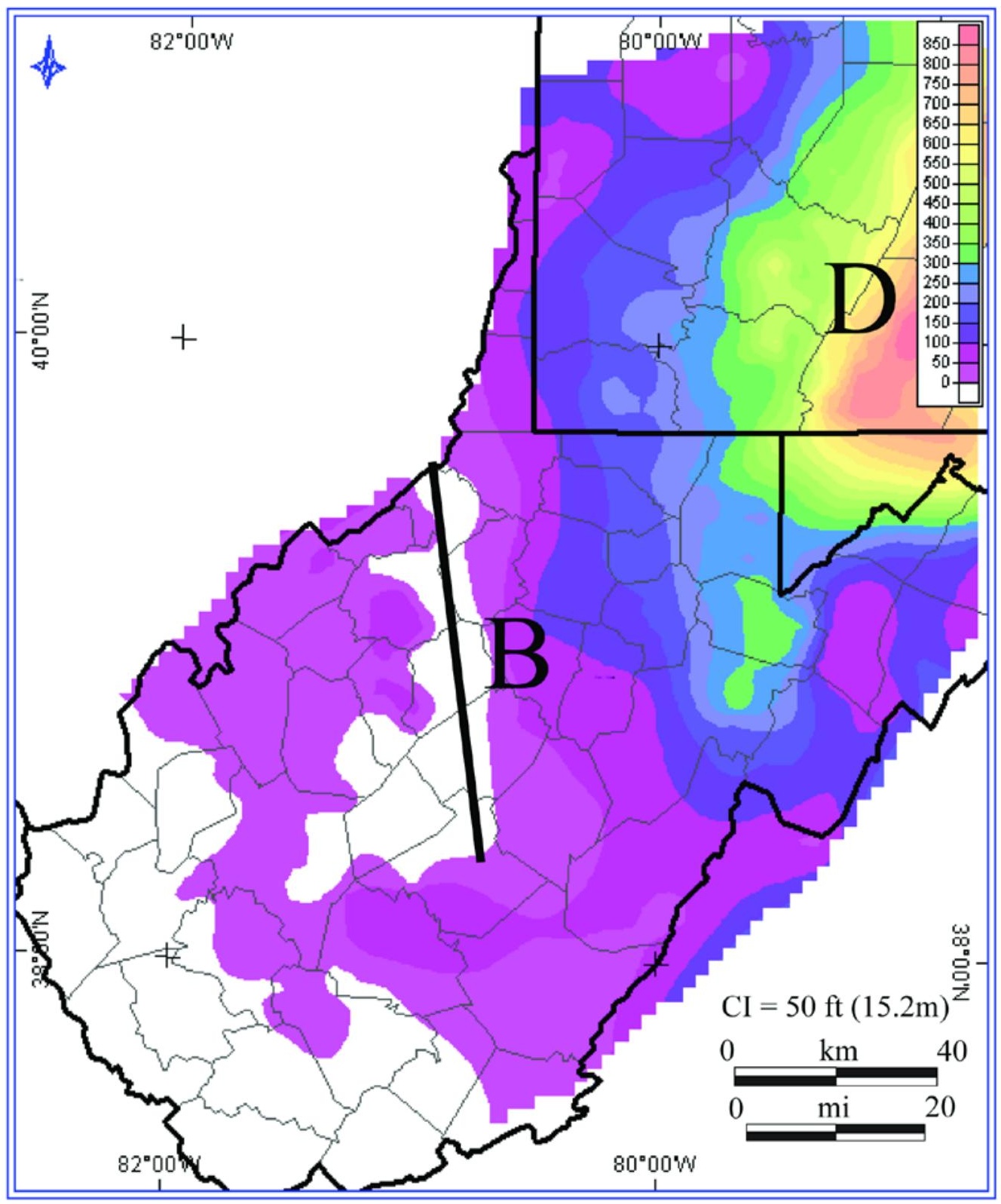

Figure 3-17. Isopach of the Mahantango Shale showing a thick (800 feet, $243.9 \mathrm{~m}$ ) in the northeast (D) of the study area and decreasing rapidly to the south and west. Contour interval (CI) is $50 \mathrm{ft}(15.2 \mathrm{~m})$. The Mahantango was not recognized in the central region of the map labeled trend $\mathrm{B}$. This is the same trend that affects the underlying Marcellus Shale and Onondaga Limestone. 


\subsection{Tully Limestone}

The contact of the Mahantango Shale and Tully Limestone as observed in logs is gradational. The Tully Limestone deposition of over 140 feet $(42.7 \mathrm{~m})$ is concentrated in the northeast where the underlying Mahantango Shale created a topographic high (Figure 3-18 and 3-19). Limestone accumulation decreases significantly to the south and we attribute this to deepening waters past the shelf break (Figure 18 and 19). However, the Tully thins and is absent to the east around the thickest accumulations of the underlying Mahantango sediment (Figure 3-17D, 3-18 D). It appears that a slow decline in sediment supply, possibly attributable to the gradual end of the initial Acadian orogenic pulse, gradually allowed the Tully Limestone to be the dominant facies in the study area. The mapped isopach trends highlight the gradational contact between the Mahantango and Tully as well as the spatial controls on thickness in relation to the presence of siliciclastics.

\subsection{Harrell Shale}

Immediately above the Tully Limestone, the final unit in the Middle Devonian sequence is the Harrell Shale. The Harrell is an organic-rich shale widespread in the subsurface (Figure 3-20). The Harrell shows significant variation in thickness at regional and local scales that appears to be related to the inherited structures observed in the underlying Middle Devonian units. Regionally, there is a distinct increase in thickness and organic matter preservation at the interpreted paleotopographic breaks in slope (Figure 3-19, 3-20). Other areas of thicker accumulation of Harrell Shale may be related to continued salt tectonics or to depositionally thinner regions in the underlying Tully Limestone. 


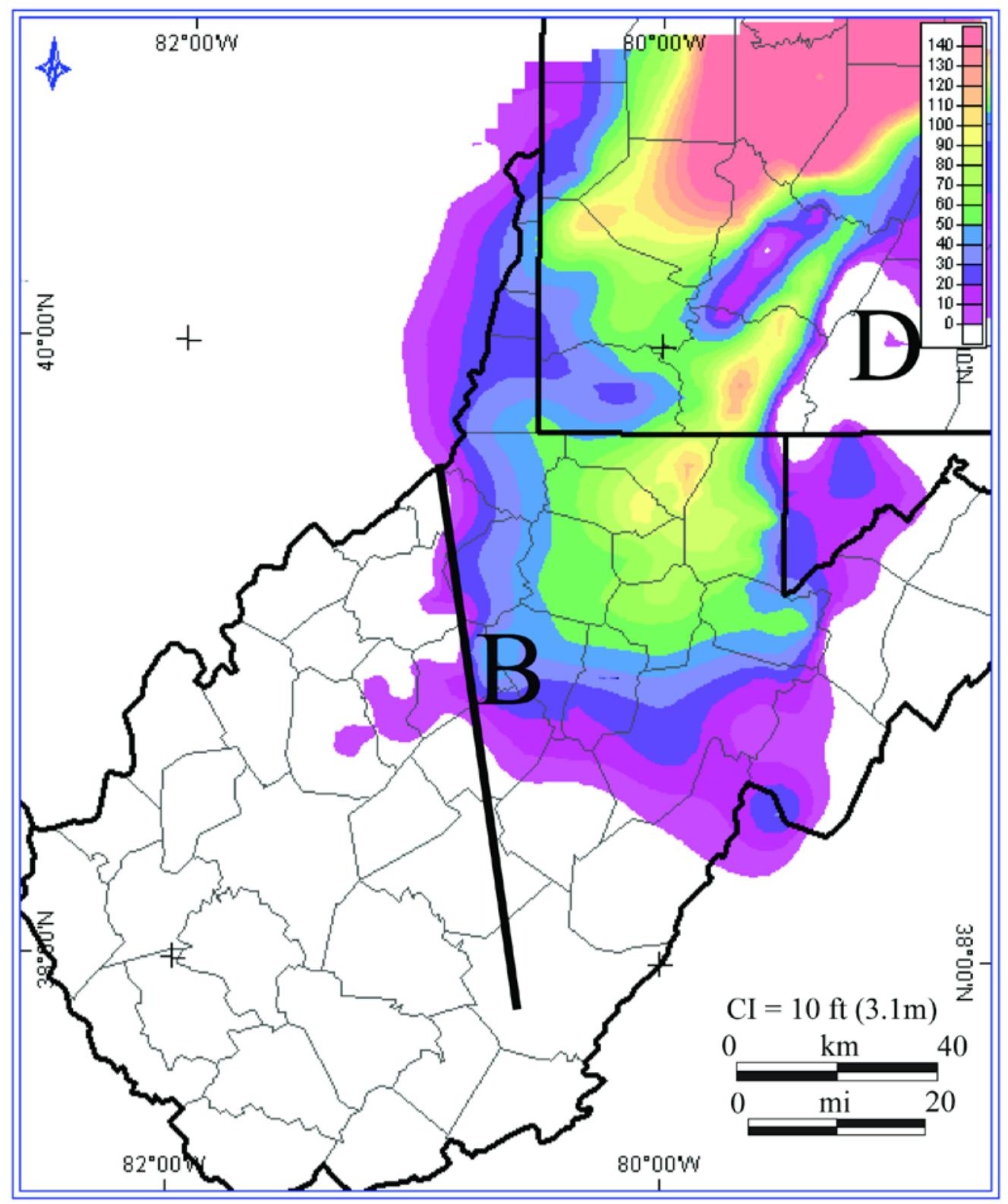

Figure 3-18. Isopach of the Tully Limestone shows a decrease in thickness to the south and east. Contour interval (CI) is $10 \mathrm{ft}(3.1 \mathrm{~m})$. The Tully is thick to the north and absent to the east (D) corresponding to the thickest Mahantango (Figure 18, D). The southern extent of the Tully Limestone is marked by a northwest to southeast trend (B). This is the same trend affecting the underlying strata and is interpreted as a slope break environment. 


\section{Harrell Deposition}

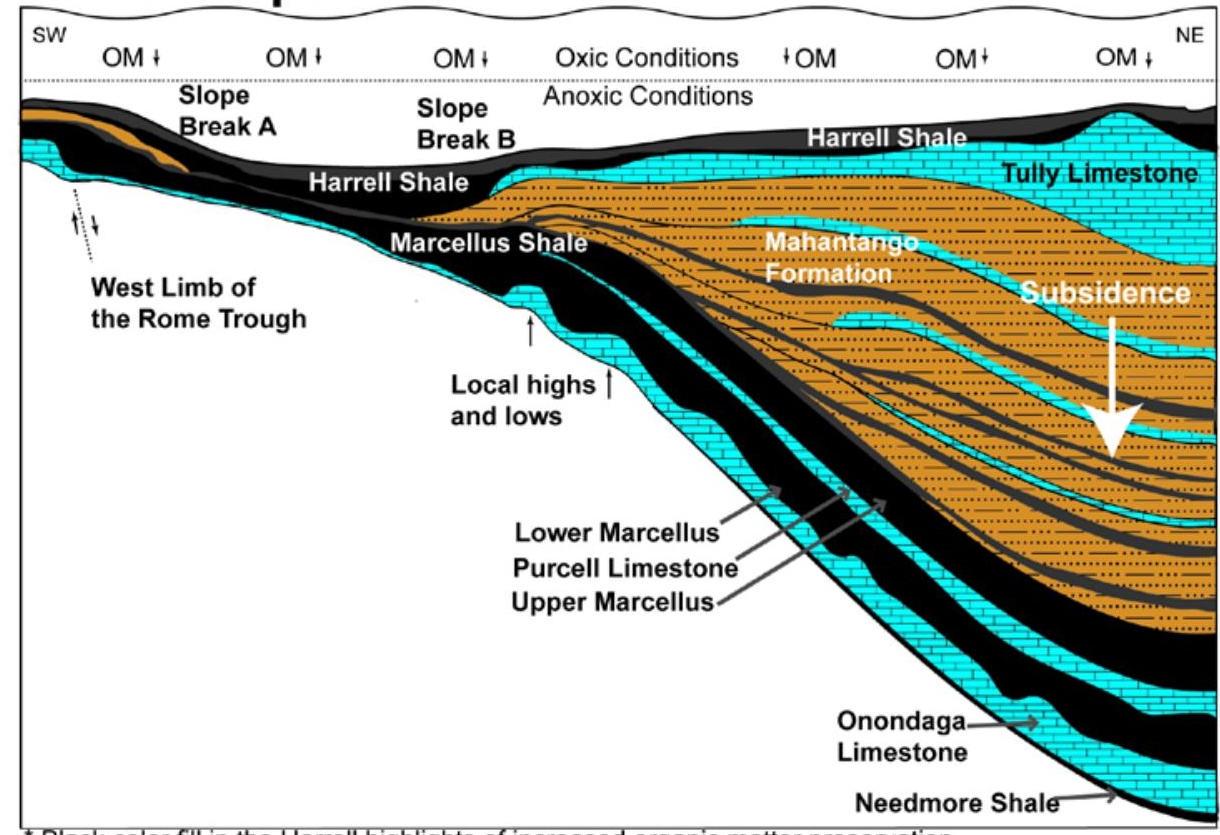

* Black color fill in the Harrell highlights of increased organic matter preservation

\section{Tully Deposition}

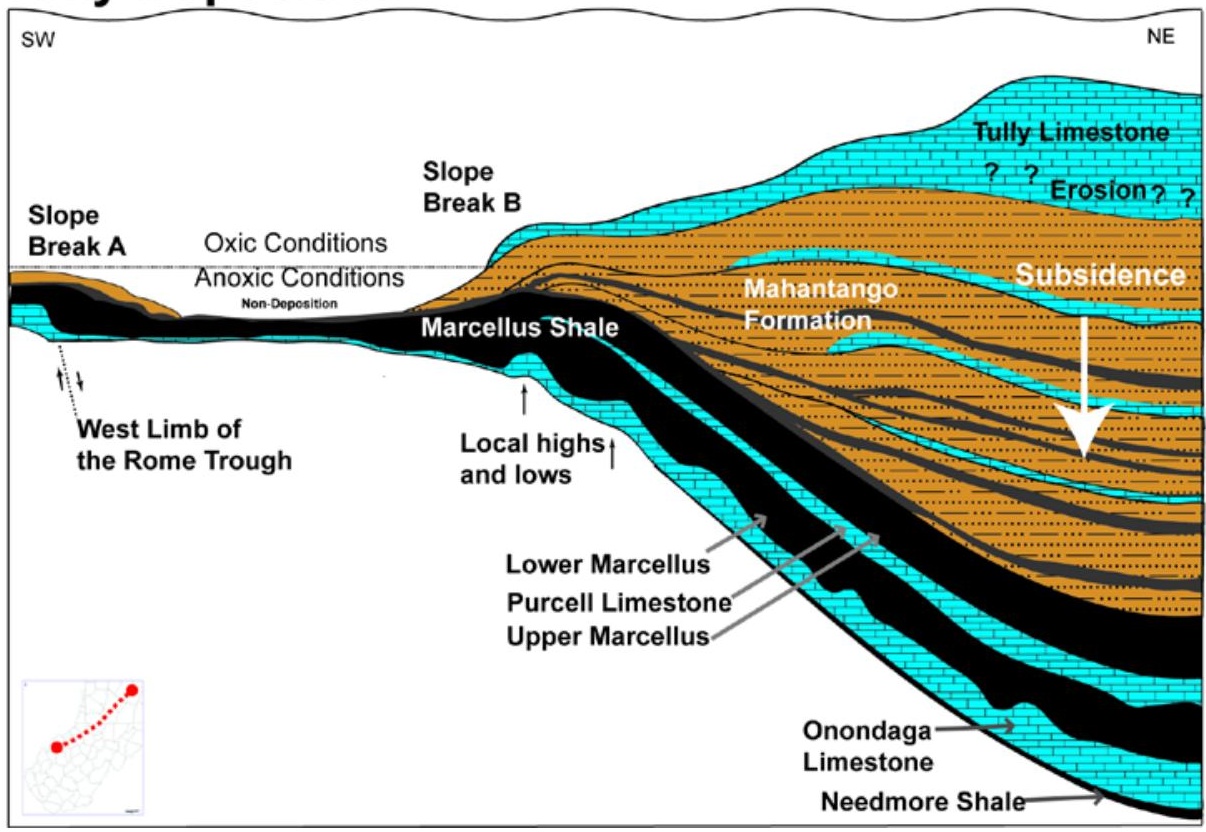

Figure 3-19. Conceptual cross-sectional depositional model for the upper two Middle Devonian units in the central Appalachian basin. Model cross-section runs from southwest Pennsylvania to western West Virginia, and highlights the slope breaks at A and B that influence deposition. The cross-secion for Harrell deposition is shaded with black in the areas that have higher organic matter preservation. 


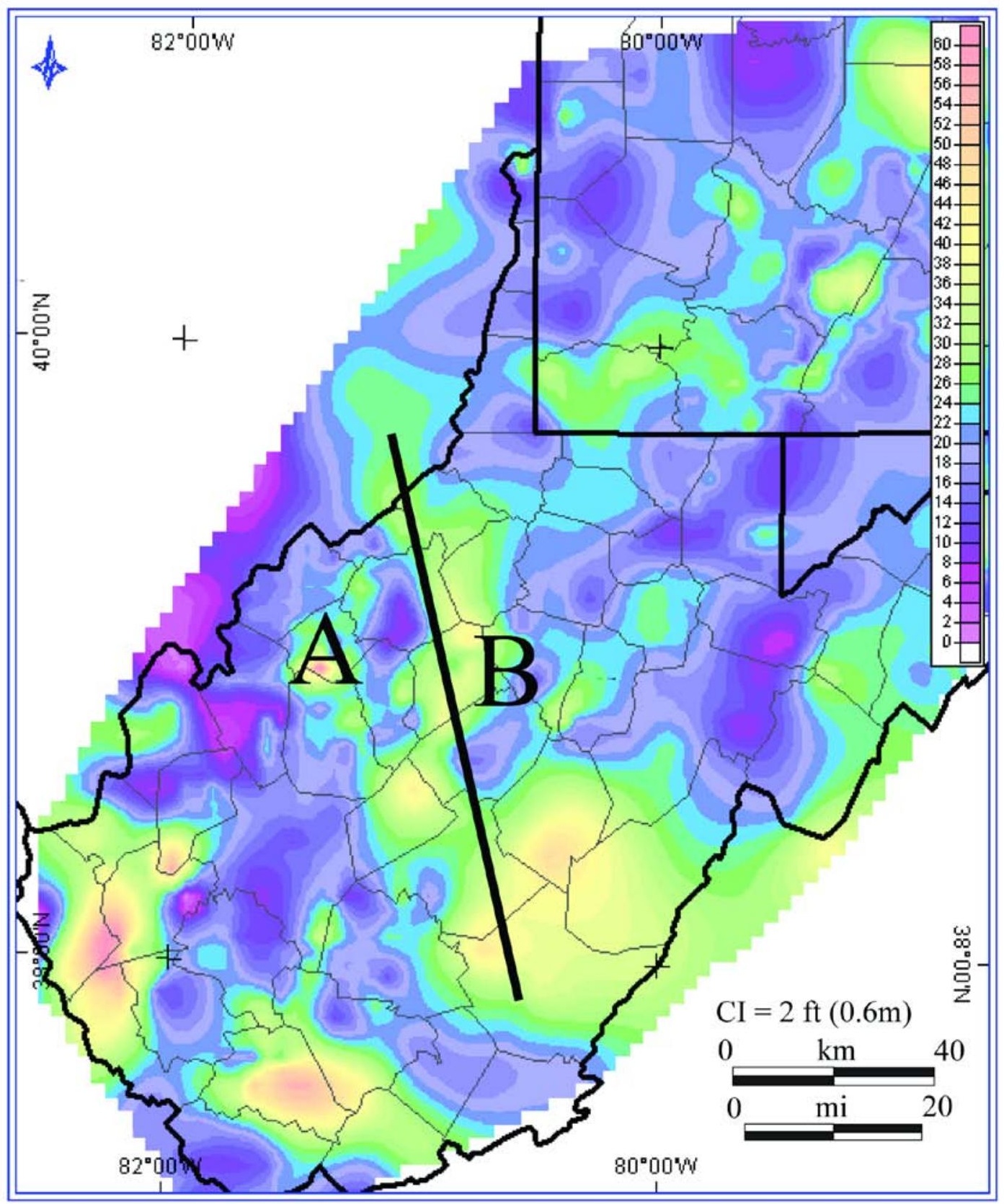

Figure 3-20. Isopach of the Harrell Shale with a contour interval of two feet $(0.6 \mathrm{~m})$. Contour interval (CI) is $2 \mathrm{ft}(0.6 \mathrm{~m})$. Deposits of the Harrell are widespread and the thicker areas ( $>40$ feet, $12.2 \mathrm{~m}$ ) are sporadic in spatial distribution with the exception that trends observed in the underlying units persist (A and B). 


\subsection{DISCUSSION AND CONCLUSIONS}

The organic-rich shale intervals of the Middle Devonian of the Appalachian basin were deposited in a foreland basin as part of an epicontinental succession across North America and have long been recognized as important source rocks and seals for hydrocarbons in the basin (Roen and Walker, 1996). Today, these units and, in particular, the Marcellus Shale are recognized as a high potential unconventional gas reservoir. The Middle Devonian of the Appalachian basin is part of a succession that was deposited during a general rise in sea level, changes in atmospheric $\mathrm{CO}_{2}$, and major changes in the biota (de Witt and others, 1993; Brenner, 1991).

A typical interpretation of organic-rich shale units, such as the Marcellus Shale, is that the shale is a distal deposit which accumulated as a condensed succession in deep water of a stratified anoxic basin that was deposited directly from suspension under quiet bottom water conditions and that the laminae of mudstones represent continuous deposition (Macquaker and Bohacs, 2007). A restricted circulation model such as the Black Sea, where the oxygen content of the water column is not renewed by circulation allowing organic-rich sediment to accumulate independent of the organic productivity, has dominated the literature for mudstones in general and for the Devonian of the Appalachian basin (e.g., Goldhaber, 1978, Tourtelot, 1979, Potter and others, 1982; Ettensohn, 1985.) Under the restricted basin model, both the environment of deposition and the sediments are anoxic. However, it has been shown that mudstones (average grain-size less that $62.5 \mu \mathrm{m}$ ) can accumulate as grain aggregates (floccules) under conditions characterized by significant currents (Schieber and others, 2007). Also, settling rates too rapid for oxidation of organic particles can be caused by the 
incorporation of organic material into floccules even if the organic particles are susceptible to oxidation. It is probably better to view the thick intervals of organic-rich shale as too little circulation in the water mass to supply oxygen at a rate fast enough to exceed the oxygen demand of the available organic matter. If enough organic material is produced, considerable oxygen could be available and organic material still would accumulate in bottom sediments. Formation of widespread accumulations of organic-rich mudstone, such as the Marcellus Shale, does not require pre-existing conditions such as a restricted basin, density stratification, or hydrogen sulfide rich waters. Abundant organic matter depletes oxygen and creates the conditions under which organic-rich shale can accumulate and one should view the accumulation of organic matter as causation of conditions of anoxia rather than an effect (Didyk and others, 1978; Tourtelet, 1979). Previous work has suggested that during the Devonian in the Appalachian basin, anoxic conditions were intermittent and the water column was mixed by storms and seasonal events (Schieber and others, 1998). In addition to settling rate, surface productivity and lack of dilution by other constituents were probably important factors in accumulation of organic-rich sediments such as the organic-rich shale intervals in the Middle Devonian of the central Appalachian basin (Didyk and others, 1978).

The Middle Devonian units in the sub-surface in the central Appalachian basin have been defined by correlating characteristics from widely available logs and tying them to core data (Boyce and Carr, 2009, this study). The definition, correlation and mapping of units across the study area were used to develop a regional depositional model for this important geologic interval. The identification of localized areas that have higher accumulations of TOC was made possible by the correlation of higher uranium content to 
higher measured TOC content from core. This relationship was extrapolated and compared to the regional and localized features observed from the interval isopachs.

Based on subsurface mapping, we have observed depositional trends that persist throughout the entire Middle Devonian including the following:

1) In the central Appalachian basin, the boundaries of the Middle Devonian units (Needmore Shale, Onondaga Limestone, Marcellus Shale, Purcell Limestone, Mahantango Shale, Tully Limestone, and Harrell Shale) are defined by a rigorous set of petrophysical criteria tied to core data and mapped across the basin.

2) In the eastern part of the study area, an apparent positive paleotopographic feature is recognized with the deposition of the Onondaga Limestone. This feature influences depositional patterns of stratigraphic units throughout the Middle Devonian and is evident in the thick accumulation of the Onondaga Limestone which rapidly thins to the west along a northwest oriented trend defining the boundary between a shelf-like feature and a basinal area defined by very thin Onondaga Limestone in central West Virginia (Trend B). The later deposition of the Purcell Limestone Member and the Tully Limestone are confined to the shelflike feature defined by the Onondaga Limestone.

3) A positive feature in western West Virginia related to the Warfield structure is on the western limb of the Rome trough (Trend A). Again, the feature influences depositional patterns throughout the Middle Devonian and is first evident in the thick accumulation of the Onondaga Limestone which rapidly thins to the east along a northwest oriented trend defining the edge of the feature and a basinal area defined by very thin Onondaga Limestone in central West Virginia. 
4) Across the area of thicker Onondaga Limestone, the Marcellus Shale displays localized changes in thickness and concentration of organic-rich shale. These areas are interpreted as correlative to relative changes in Onondaga thickness and appear to be related to localized structures resulting from salt tectonics or reactivation of pre-existing structures during the initial pulses of the Acadian Orogeny.

5) Regionally, using the relationship of predicted uranium content from the fullspectrum gamma ray log, two distinct depositional trends of the organic-rich Marcellus Shale were recognized. The area labeled trend A appears to be related to the area along the east edge of the Warfield structure. The positive feature is characterized by thicker Onondaga Limestone deposition. Just off the paleotopographic high there is enhanced generation and accumulation of organicrich mudstone that was deposited during the Marcellus Shale and later Harrell Shale depositional time period (Trend A). A similar depositional pattern was recognized along the edge of the main paleotopographic high to the east (Trend B).

6) The Mahantango Shale forms a relatively thick (>800 ft, $250 \mathrm{~m})$ prograding wedge that represents the first pulse of coarser siliciclastic material that will form the Catskill delta in northeast Pennsylvania (Faill, 1985). As mapped, the Mahantango terminates to the southwest along the feature first defined by the Onondaga Limestone. There may be a western source (Cincinnati Arch?) for the thin Mahantango Shale mapped in western West Virginia. 
Key reservoir parameters for unconventional gas shale deposits, such as the Marcellus Shale, include: thermal maturity, thickness, total organic carbon (TOC) content, gas fraction (adsorbed and free in pores and fractures), and permeability. By using the spectral gamma ray suite, specifically, the uranium curve we have derived an estimate for two important factors in the Marcellus and related organic-rich Middle Devonian shale units: total organic carbon and potential gas content. The identification of this relationship is tied to depositional patterns by identifying areas along changes in paleoslope and localized structures where organic material was most probable to be generated in sufficient enough quantities to facilitate preservation. In summary, the areas of highest TOC are identified by their relation to the underlying structure at the time of deposition and not by the gross unit thickness of the shale. 


\subsection{REFERENCES CITED}

Adams, J.A.S. and Weaver, C. E., 1958, Thorium and uranium ratios as indications of sedimentary process: Example of concept of geochemical facies; American Association of Petroleum Geologists Bulletin, v. 42, p. 387-430.

Anderson, R. J. et. al.,1984, American Association of Petroleum Geologists Correlation Chart; Series 1984.

Beers, R. F., 1945, Radioactivity and organic content of some Paleozoic shales: AAPG Bulletin, vol. 29, p. 1-22.

Berner, R.A., 1991, A model for atmospheric CO2 over Phanerozoic time: American Journal of Science, v. 291, p. 339-376.

Bohacs, K., MacQuaker, J., Lazar, O. R., Jonk, R., Hemmesch, N., Cassel, E. J., 2009, Detailed anatomy of parasequences in mudstone-dominated, allegedly anoxic settings: examples from the Cretaceous Mowry Shale and associated formations, western U.S.: AAPG Annual Convention and Exhibition, Denver, Colorado, June 7-10.

Boyce, M. L., Carr, T.R., 2009, Lithostratigraphy and petrophysics of the Devonian Marcellus interval in West Virginia and southwestern Pennsylvania: $29^{\text {th }}$ Annual GCSEPM Foundation Bob F. Perkins Research Conference, Houston, Texas; Unconventional Energy Resources; Making the Unconventional Conventional, p. 254281.

Brett, C. E. and C. A. Ver Straeten, 1994, Stratigraphy and facies relationships of the Eifelian Onondaga Limestone (Middle Devonian) in western and west central New York State: field trip guidebook: New York State Geological Association: 66th annual meeting, Guidebook - New York State Geological Association, Meeting, v. 66, p. 221-270.

Chute, N. E., 1972, Subsurface stratigraphy and structure near the Morton Salt Company's Mine on Seneca Lake, New York: Northeastern Section, 7th Annual Meeting, Abstracts with Programs - Geological Society of America, v. 4, no. 1, p. 9-10.

Demaison, G. J. and G. T. Moore, 1980, Anoxic environments and oil source bed genesis: AAPG Bulletin, v. 64, no. 8, p. 1179-1209.

De Witt, W. J., Roen, J. B., and Wallace, L. G., 1993, Stratigraphy of Devonian black shales and associated rocks in the Appalachian Basin, in Roen, J. B., and Kepferle, R. C., eds., Petroleum geology of the Devonian and Mississippian black shale of eastern North America, Volume 1909: U.S. Geological Survey Bulletin, B1-B57.

Didyk, B.M., Simoneit, B.R.T., Brassel, S. C. and Eglinton, G., 1978, Organic geochemical indicators of palaeoenvironmental conditions of sedimentation; Nature, v. 272, p. 216-222. 
Duke, W.L., Prave, A.R., Al-Hajri, S., Cuffey, C.A., Ericksen, M.C., Fisler, D.K., Guebert, M.D., Matthews, J.C., Narehood, S.E., Ritter, J.B., and Vogel, K.R., 1991, Storm-and tide-influenced prograding shoreline sequences in the Middle Devonian Mahantango Formation, Pennsylvania; Clastic tidal sedimentology: Memoir - Canadian Society of Petroleum Geologists, v. 16, p. 349-369.

Ettensohn, F. R. and L. S. Barron, 1982, A tectonic-climatic approach to the deposition of the Devonian-Mississippian black-shale sequence of North America: Proceedings of the 1982 Eastern oil shale symposium, Proceedings - Eastern Oil Shale Symposium, v. 1982, no. IMMR82-075, p. 5-37.

Ettensohn, F.R., 1985, Controls on development of the Catskill Delta complex basin facies, in D. L. Woodrow and W. D. Sevon, eds., The Catskill Delta, Geological Society of America Special Paper, 201, p. 65-77.

Ettensohn, F. R., 1998, Compressional tectonic controls on epicontinental black-shale deposition; Devonian-Mississippian examples from North America, in Schieber, J., W. Zimmerle, and P. S. Sethi, eds.: Shales and mudstones; I, Basin studies, sedimentology, and paleontology, Federal Republic of Germany (DEU), E. Schweizerbart'sche Verlagsbuchhandlung Naegele u. Obermiller, Stuttgart, Federal Republic of Germany (DEU).

Faill, R.T., 1985, The Acadian orogeny and the Catskill Delta, in Woodrow, D.L., and Sevon, W.D., editors, The Catskill Delta: Geological Society of America Special Paper 201, p. 15-37.

Fertl, W. H., and H. H. Rieke, 1980, Gamma-ray spectral evaluation techniques identify fractured shale reservoirs and source-rock characteristics: Journal of Petroleum Technology, v. 31, p. 2053-2062.

Gao, D. and R. C. Shumaker, 1996, Subsurface geology of the Warfield structures in southwestern West Virginia; implications for tectonic deformation and hydrocarbon exploration in the central Appalachian basin: AAPG Bulletin, v. 80, no. 8, p. 1242-1261.

Gao, D., R. C. Shumaker, and T. H. Wilson, 2000, Along-axis segmentation and growth history of the Rome trough in the central Appalachian basin: AAPG Bulletin, v. 84, no. 1, p. 75-99.

Gold, R, 2008, Gas producers rush to Pennsylvania: promising results there spur investment: The Wall Street Journal. page A2.

Goldhaber, M.B., 1978, Euxinic facies, in R. Fairbridge and J. Bourgeois, eds., The Encyclopedia of Sedimentology, Dowden, Hutchinsom and Ross, Inc., Stroudsburg, Pennsylvania, p. 296-300. 
Harrison, M. J., S. Marshak, and J. H. McBride, 2004, The Lackawanna synclinorium, Pennsylvania; a salt-collapse structure, partially modified by thin-skinned folding: Geological Society of America Bulletin, v. 116, no. 11-12, p. 1499-1514.

Hasson, K. O. and J. M. Dennison, 1988, Devonian shale lithostratigraphy, central Appalachians, U.S.A: Devonian of the world; proceedings of the Second international symposium on the Devonian System; Volume II, Sedimentation, Memoir - Canadian Society of Petroleum Geologists, v. 14, p. 157-177.

Lash, G. G. and Engelder, T., accessed June 7, 2010, The Middle Devonian Marcellus Shale - a record of eustacy and basin dynamics: Search and Discovery Article 30104, http://www.searchanddiscovery.net/documents/2009/090805lash/ndx_lash.pdf.

Linsley, D. M., 1991, Coarsening-up cycles and stratigraphy of the upper part of the Marcellus and the Skaneateles Formation in central New York: Dynamic stratigraphy and depositional environments of the Hamilton Group (Middle Devonian) in New York State, Part II: Bulletin - New York State Museum (1976), v. 469, p. 75-92.

Macquaker, J.H.S., and K. M. Bohacs, 2007, On the accumulation of mud; Science, v. 318, p. 1734-1735.

Macquaker, J., Mcllroy, D., Davies, S. J., Keller, M. A., 2009, Not anoxia! How do you preserve organic matter then?: AAPG Annual Convention and Exhibition, Denver, Colorado, June 7-10, 2009.

Passey, Q, Creaney, S., Kulla, J., Moretti, F., Stroud, J., 1990, A practical model for organic richness from porosity and resistivity logs: AAPG Bulletin, v. 74, no. 12, p. 1777-1794.

Potter, P. E., Maynard, J. B., and Pryor, W. A., 1982, Appalachian gas beraing Devonian shales: Statements and discussions, Oil and Gas Journal, v. 80, p. 290-318.

Roen, J.B., and Walker, B.J., eds., 1996, The atlas of major Appalachian gas plays: West Virginia Geological and Economic Survey Publication V-25, 201 p.

Scheiber, J., 1994, Evidence for high-energy events and shallow-water deposition in the Chattanooga Shale, Devonian, central Tennessee, USA; Sedimentary Geology, v. 93, p. 193-208.

Schieber, J., 1998, Sedimentary features indicating erosion, condensation and hiatuses in the Chattanooga Shale of Central Tennessee - relevance for sedimentary and stratigraphic evolution, in Schieber, J., Zimmerle, W., and Sethi, pP., eds., Shales and mudstones, Volume I; E. Schweizerbart'she Verlagsbuchhandlung (Nagele u. Obermiller), p. 187-215. 
Schieber, J., Southard, J. and Thaisen, K., 2007, Accretion of mudstone beds from migrating floccules ripples; Science, v. 318, p.1760-1763.

Schmoker, J. W., 1981, Determination of organic-matter content of Appalachian Devonian shales from gamma-ray logs: AAPG Bulletin, vol. 65, p. 1285-1298.

Swezey, C. S., 2002, Regional stratigraphy and petroleum systems of the Appalachian basin, North America: Geologic Investigations Series - U.S.Geological Survey, v. I-2768.

Tourtelot, H. A., 1979, Black shale-Its deposition and diagenesis; Clays and Clay Minerals, v. 27, p. 313-321.

Wilson, T. H., 2000, Seismic evaluation of differential tectonic subsidence, compaction, and loading in an interior basin: AAPG Bulletin, v. 84, no. 3, p. 376-398. 


\section{SUMMARY}

The Middle Devonian interval across the central Appalachian basin of West Virginia and southwest Pennsylvania is a complex and economically important depositional sequence. The depositional complexities make economic and geologic evaluation difficult on both a local and regional basis. In this study, core and well log data were used to generate regional maps, identify depositional trends and create methods to identify and evaluate gas-rich zones in shale units of the Middle Devonian interval. The findings in this investigation led to the following conclusions:

1) Lithostratigraphic boundaries were established in the sub-surface for the Middle Devonian using a multiple well log approach with well-defined petrophysical criteria. The defined petrophysical criteria allowed for the development of a consistent lithostratigraphic framework across the study area.

2) The mineralogical and fluid content in the Middle Devonian interval can severely affect standard well logs such as the bulk density tool or photo electric log.

3) A strong correlation exists between intervals of increased organic-richness and increased uranium content as determined from the spectral gamma ray $\log$.

4) A measure of organic richness can be computed from the standard gamma-ray $\log$ calibrated to the uranium log of the spectral gamma ray log suite and used to regionally map interpreted organic richness. 
5) Using a cross-plot, the density porosity log and the uranium log is used to identify gas-rich intervals in the shale units of the Middle Devonian interval.

6) The potassium, uranium and thorium concentrations derived from the spectral gamma ray tool can be used to determine clay type, identify ash beds, and better understand fluctuations in redox conditions through the Middle Devonian shale intervals.

7) The uranium and thorium logs of the spectral gamma ray can be incorporated into modified Archie water saturation equations to improve prediction of gas and water saturations in shale intervals of the Middle Devonian.

8) During the Middle Devonian control on the accumulation and preservation of organic material was a complex process incorporating regional and local paleotopography and distance from clastic sediment source.

9) Localized paleo-structures (i.e. salt tectonics and reactivated features) enhanced organic matter preservation.

10) Regional features were identified that affected the deposition of all of the units in the Middle Devonian. These trends created paleotopographic (shelf-break) environments, creating for conditions favorable for the production and accumulation and preservation of organic matter. These organic-rich trends can be mapped and define a north-south fairway of higher organic richness and potential increased gas reserves in the Marcellus Shale and related Middle Devonian shale units. 


\begin{abstract}
APPENDIX
Two cross-sections are included in this study to help illustrate the correlations of this study and will be included in the jacket of this document. One cross-section is oriented north east to south west (Cross-section 1, A-A`) and the other is oriented west to east (Cross-section 2, B-B').
\end{abstract}




\section{Cross-section 2}
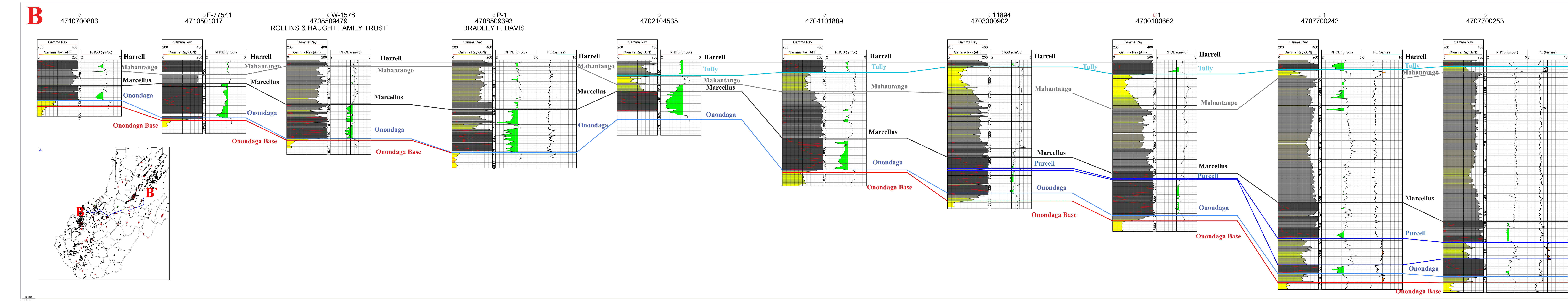

4

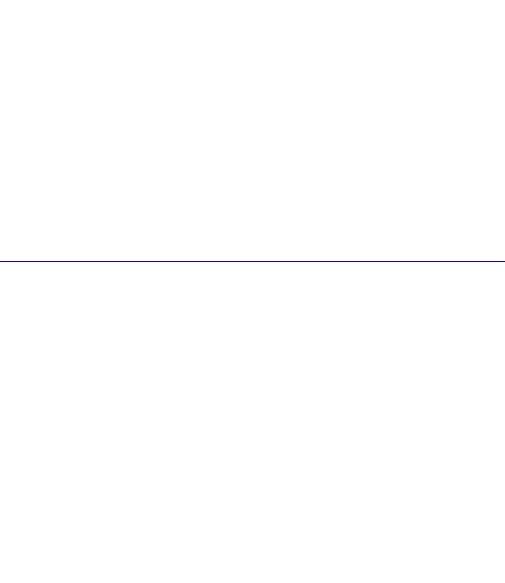

